\title{
Caprellidae (Crustacea: Amphipoda) from the Great Barrier Reef and Adjacent Localities
}

\author{
José M. GuerRA-GARCÍA \\ Laboratorio de Biología Marina, Departamento de Fisiología y Zoología, \\ Facultad de Biología, Universidad de Sevilla, Avda Reina Mercedes 6, 41012 Sevilla, Spain \\ jmguerra@us.es
}

\begin{abstract}
The caprellid fauna of the Great Barrier Reef region is investigated. The study reports 22 species in 17 genera. Three new genera and seven new species are described (Hircella berentsae n.sp., Jigurru vailhoggett n.gen., n.sp., Mayericaprella arimotoi n.gen., n.sp., Orthoprotella pearce n.sp., Perotripus keablei n.sp., Pseudoprellicana johnsoni n.gen., n.sp. and Quadrisegmentum lowryi n.sp.). All species are figured and a key to the species is provided. An ecological study conducted at Lizard Island, northern Great Barrier Reef, showed that Metaprotella sandalensis Mayer, 1898 and Quadrisegmentum triangulum Hirayama, 1988, were the most common species in the coral reef system. Although the caprellids were present at most sites around the Island, they were abundant only on hydroid and sediment substrates.
\end{abstract}

Guerra-García, José M., 2006. Caprellidae (Crustacea: Amphipoda) from the Great Barrier Reef and adjacent localities. Records of the Australian Museum 58(3): 417-458.

Caprellid amphipods are small peracaridan crustaceans important as secondary and tertiary producers in marine ecosystems. They are common on algae, hydroids, bryozoans, sponges and seagrasses (McCain, 1968), and are important prey for many coastal fish species (Caine, 1987, 1989, 1991). Recently, caprellids have been found to be useful bioindicators of marine pollution and environmental stress (Guerra-García \& García-Gómez, 2001; Takeuchi et al., 2001) adding impetus to understand the taxonomy and systematics of this group of crustaceans.

The Caprellidae of the Great Barrier Reef have not been previously studied. The scarce work existing on the Amphipoda of this area has focused on the Gammaridea; K.H. Barnard (1931) reported 14 species of gammaridean amphipods collected by the 1928-1929 Great Barrier Reef Expedition, and Berents (1983) conducted the first study of the melitid gammarideans from tropical Australia. McCain \& Steinberg (1970) listed 27 caprellid species from Australian waters, 14 in New South Wales, seven in Western
Australia, three in Victoria and nine in Tasmania, but none from Queensland. Apart from the revision of McCain \& Steinberg (1970), no taxonomic studies on the Caprellidae have been conducted along the Great Barrier Reef, and the only recorded species are those listed in ecological papers on benthic communities. In a list of the Crustacean species inhabiting the soft bottoms communities from Lizard Island, Queensland, Jones (1984) reported two caprellid species: Metaprotella sp. and Phtisica marina Slabber, 1769. Jones' (1984) specimens, deposited in the collections of the Australian Museum, are referable to Metaprotella sandalensis Mayer, 1898 and Metaproto novaehollandiae (Haswell, 1880) respectively.

The present study reports on the Caprellidae of the Great Barrier Reef and adjacent localities based primarily on museum collections. Additionally, a field study was conducted at Lizard Island in October 2001 to collect abundant material and to study habitat use by caprellids in a coral reef system. 


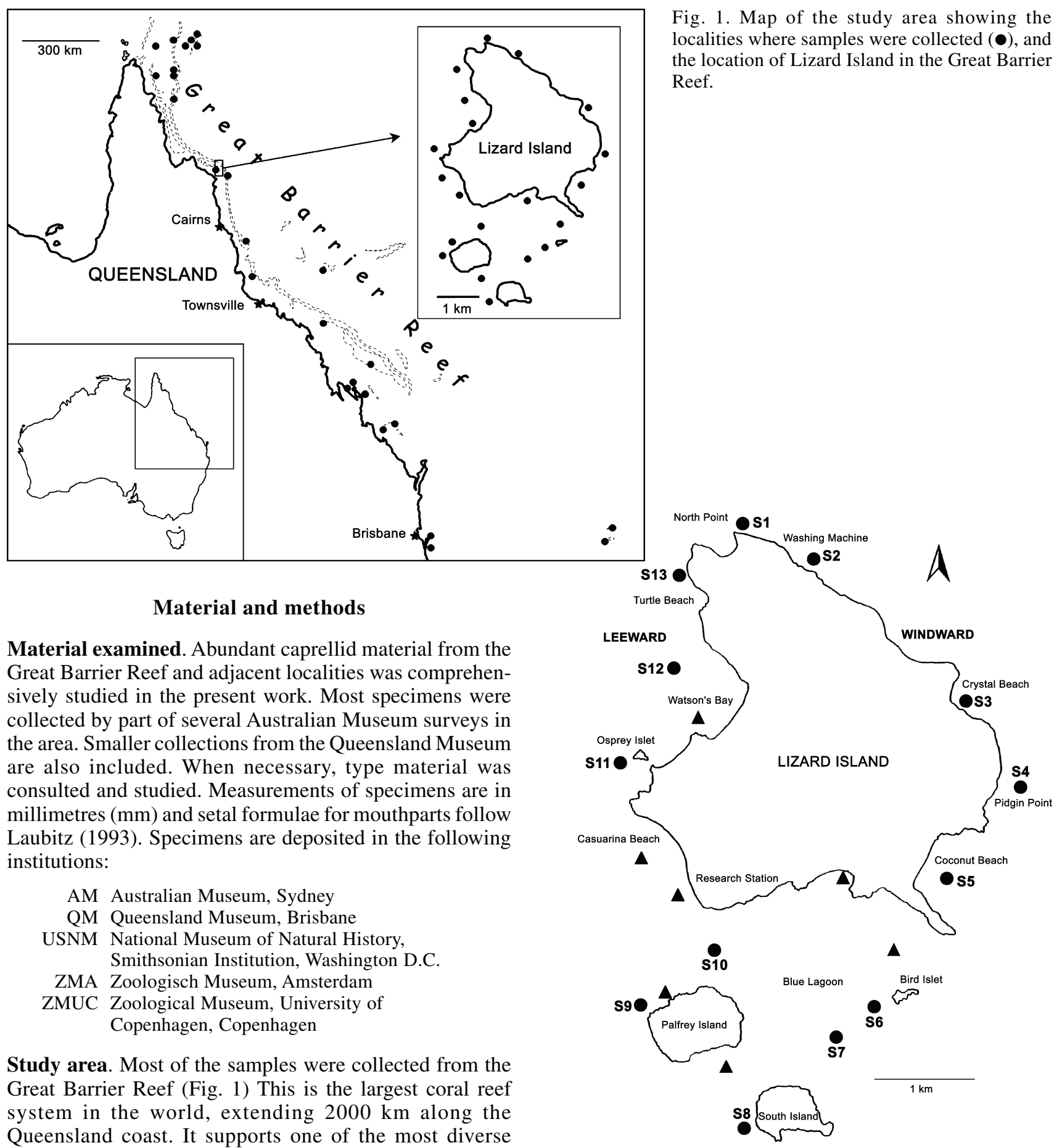
Queensland coast. It supports one of the most diverse ecosystems known, including a rich diversity of coastal habitats, coral reefs and cays, and continental islands. In addition to the samples from the Great Barrier Reef, collections from other areas of Queensland and the Tasman Sea, such as Shoalwater Bay, the coast near Brisbane, Middleton and Elizabeth Reefs, and Lord Howe Island, were studied in the present work. On the coast around Shoalwater Bay different habitats, as mangroves and seagrass beds, were sampled; most of this sampling area were characterized by wide tidal range, strong currents, not clear waters, and silty reefs. The fringing coral reef at Lord Howe Island is the southernmost in the world and the reefs at Elizabeth and Middleton Reefs represent the southernmost coral atolls. Elizabeth and Middleton Reefs are located about $725 \mathrm{~km}$ south of the southern end of the Great Barrier Reef and 95

Fig. 2. Map of Lizard Island showing the sampling sites. Circles $(\bullet)$ indicate the localities sampled on SCUBA (numbered S1 to S13 for multivariate analysis) and the triangles $(\mathbf{\Delta})$ the stations sampled on snorkel.

$\mathrm{km}$ north of Lord Howe Island. Although coral species are fewer than on tropical reefs, the coral in these areas show few signs of human impact. Further details regarding Lord Howe Island, Middleton and Elizabeth Reefs can be found in Recher \& Ponder (1981) and Whitley (1937), respectively.

Lizard Island. Lizard Island $\left(14^{\circ} 40^{\prime} \mathrm{S} 145^{\circ} 28^{\prime} \mathrm{E}\right)$ is a tropical, granitic, continental island c. $7 \mathrm{~km}^{2}$ in area, located in the northern region of the Great Barrier Reef (Fig. 1). It is almost entirely fringed by coral reefs, which extend to 
encompass two nearby islands (South and Palfrey) and a 10-12 m deep lagoon (Blue Lagoon) (Fig. 2). Lizard Island supports a diverse range of habitats: reef flats and slopes, algae and seagrass beds, coral rubble, fine and coarse sediments, and mangroves. A more detailed description of the island is given in Keable (1995), and a characterization of the sediments is given in Fisk (1983) and Jones (1984).

General collections along the Great Barrier Reef and adjacent localities. Most of the Great Barrier Reef material studied here was collected by the Australian Museum (see Station List in the Appendix). The purpose of these samplings was to collect small marine invertebrates, like amphipods and another peracarid crustaceans. Intertidal samples were collected by hand at low tide. Sublittoral samples were taken on SCUBA. Collecting techniques varied according to habitat. The majority of the samples were collected by hand, using fine nylon mesh bags or plastic bags. Occasionally, an air-lift was used to sample sediments and the epifauna of coral heads and gorgonians. Some samples of reef rock and dead coral were taken using a hammer and chisel. Samples were fixed in $7 \%$ neutralized formalin, and transferred to $70 \%$ ethanol.

Field study at Lizard Island. A sampling programme targeting caprellids was conducted at Lizard Island in October 2001. Twenty sites were sampled around the island, thirteen on SCUBA, and seven on snorkel (Fig. 2). These covered a wide diversity of habitats from the intertidal to $27.5 \mathrm{~m}$ deep. At each station, along a decreasing deep transect, the different habitats were explored and about 200 samples of potential substrates for the Caprellidae were collected (Table 1), including algae (20 species), seagrasses (3 species), sponges (18 species), hydroids (9 species), gorgonians (5 species), soft corals (4 species), bryozoans (3 species), ascidians (4 species), encrusted dead corals, coral rubble, fine and coarse sediments and mangroves. Although the echinoderms and most of the hard corals were not directly sampled, they were checked for caprellids "in situ". The most abundant algae were Halimeda micronesica, H. macroloba, H. cilindracea, Padina cf. gymnospora, Galaxaura marginata and Turbinaria ornata. The seagrasses were dominated by Halophila spp., which alternate with the algae, Caulerpa spp. Among the sponges were common Spirastrella vagabunda and Pericharax heteroraphis. The most common hydroids were Macrorhynchia philippina and Aglaophenia cupressina. The gorgonians Junceella spp. and Mopsella spp., and the soft coral Nephtea spp. were common at some sites. The bryozoans were seldom encountered, although Heteroprellina denticulata was present at several localities. The tunicate Polycarpa aurata was widely distributed along the whole island. Fine to coarse shelly sediments were sampled, on some occasions containing great amounts of the large foraminifera Marginopora vertebralis. Mangrove habitats, dominated by Rizophora sp., were also sampled.

The soft bottom samples were collected by hand, using fine nylon mesh bags that were dragged five to ten meters along the bottom. Other samples were placed in fine mesh or plastic bags. To avoid damage to specimens caused by

Table 1. Species composition of the Caprellidae collected from Lizard Island, Queensland, Australia. The qualitative values of abundance of caprellids in the different habitats are included. Qualitative scale: ${ }^{\circ}$ absent; $\bullet$ rare $(1-10$ individuals/sample); $\bullet \bullet$, common $(10-100$ ind/sample); $\bullet \bullet$, very common (>100 ind/sample). All the data included in the table were collected during the sampling programme at Lizard Island in October 2001 except for Pseudoprellicana johnsoni (not found in October 2001, and the data are taken from previous surveys at Lizard Island) and Quadrisegmentum lowryi (data combined, collected from sponges in October 2001 but on coral rubble in previous surveys).

\begin{tabular}{|c|c|c|c|c|c|c|c|c|c|c|c|c|c|}
\hline & $\begin{array}{l}\mathbb{\mathscr { J }} \\
\frac{0}{\pi} \\
\end{array}$ & 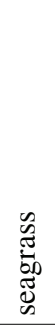 & $\begin{array}{l}\infty \\
0 \\
00 \\
0 \\
0 \\
\infty\end{array}$ & 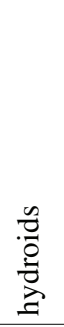 & 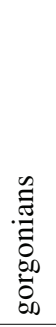 & 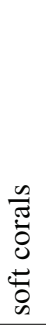 & 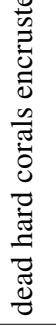 & 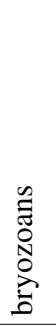 & 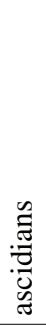 & $\begin{array}{l}\frac{0}{0} \\
\frac{0}{3} \\
\frac{\pi}{3} \\
0 \\
0\end{array}$ & 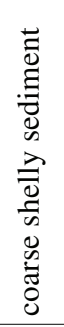 & 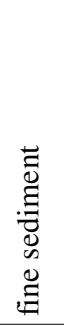 & 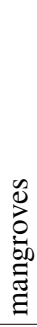 \\
\hline number of samples & 45 & 12 & 25 & 25 & 12 & 4 & 17 & 4 & 7 & 13 & 14 & 10 & 4 \\
\hline Aciconula australiensis Guerra-García, 2004 & ० & o & ० & $\bullet$ & ० & $\circ$ & $\bullet$ & o & $\circ$ & ० & o & ० & ० \\
\hline Hemiaegina minuta Mayer, 1890 & ○ & ० & $\circ$ & $\bullet$ & ० & $\circ$ & $\circ$ & ○ & $\circ$ & o & ० & ० & ० \\
\hline Jigurru vailhoggett n.gen., n.sp. & O & ○ & ○ & ○ & $\circ$ & $\circ$ & $\bullet$ & ○ & $\circ$ & ० & ० & ० & o \\
\hline Metaprotella sandalensis Mayer, 1898 & $\bullet$ & $\bullet$ & $\bullet$ & $\bullet \bullet$ & $\bullet$ & $\bullet$ & $\bullet$ & $\bullet$ & $\bullet$ & $\bullet$ & $\bullet$ & $\bullet$ & $\bullet$ \\
\hline Metaproto novaehollandiae (Haswell, 1880) & ○ & O & ○ & ○ & ○ & $\circ$ & ○ & ○ & $\circ$ & ० & $\bullet \bullet \bullet$ & $\bullet \bullet \bullet$ & $\circ$ \\
\hline Orthoprotella australis (Haswell, 1880) & O & ○ & ○ & $\bullet \bullet \bullet$ & $\circ$ & $\circ$ & ० & ○ & $\bullet$ & ० & ○ & ० & ० \\
\hline Orthoprotella mayeri Barnard, 1916 & ○ & O & ० & $\bullet$ & ० & $\circ$ & ० & ० & ○ & ० & ० & O & ० \\
\hline Orthoprotella pearce n.sp. & o & o & ० & $\bullet \bullet$ & ० & $\circ$ & ० & o & ० & ० & ० & ० & ० \\
\hline Perotripus keablei n.sp. & ० & ० & ० & ○ & ○ & ○ & $\circ$ & ० & ○ & ० & $\bullet$ & $\bullet$ & o \\
\hline Protella similis Mayer, 1903 & ○ & ० & $\bullet$ & $\bullet \bullet \bullet$ & ० & $\circ$ & ० & ० & $\circ$ & ० & $\bullet$ & ० & ० \\
\hline Protogeton inflatus Mayer, 1903 & O & O & ० & O & ○ & $\circ$ & ० & O & ○ & ० & O & $\bullet$ & ० \\
\hline Pseudaeginella biscaynensis (McCain, 1968) & O & ○ & ○ & $\bullet$ & ○ & $\circ$ & ० & ○ & $\circ$ & ○ & ○ & ○ & ० \\
\hline Pseudoprellicana johnsoni n.gen., n.sp. & ○ & O & ० & O & ○ & ○ & ० & ० & ० & ० & $\bullet$ & O & ० \\
\hline Pseudoproto fallax Mayer, 1903 & ○ & ○ & ○ & ○ & ○ & $\circ$ & $\bullet$ & ○ & $\circ$ & ० & ○ & ○ & $\circ$ \\
\hline Quadrisegmentum lowryi n.sp. & O & O & $\bullet$ & ○ & ○ & $\circ$ & ० & ○ & $\circ$ & $\bullet$ & ○ & ० & ० \\
\hline Quadrisegmentum triangulum Hirayama, 1988 & $\bullet$ & $\bullet$ & $\bullet$ & ○ & $\bullet \bullet$ & $\circ$ & $\bullet$ & ○ & $\bullet$ & $\bullet$ & 0 & 0 & 0 \\
\hline
\end{tabular}




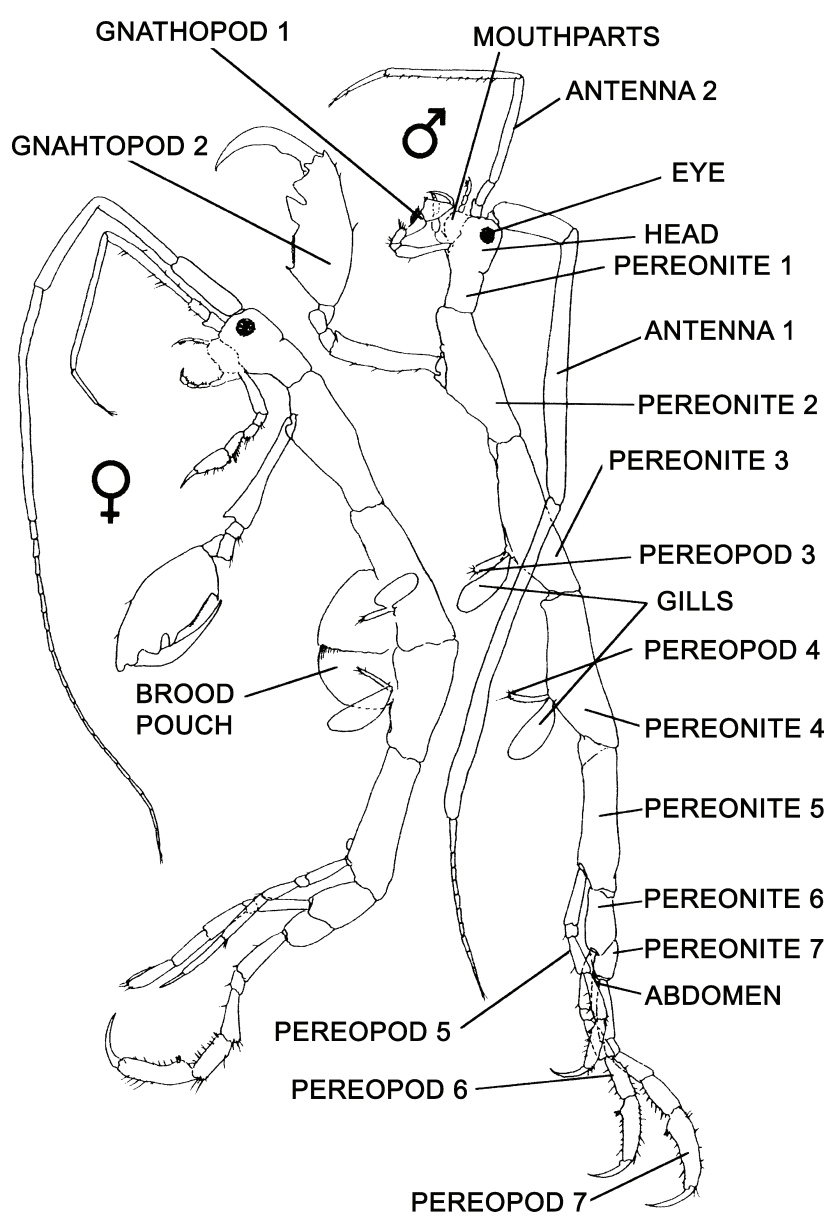

Fig. 3. Lateral view of a generalized caprellid.
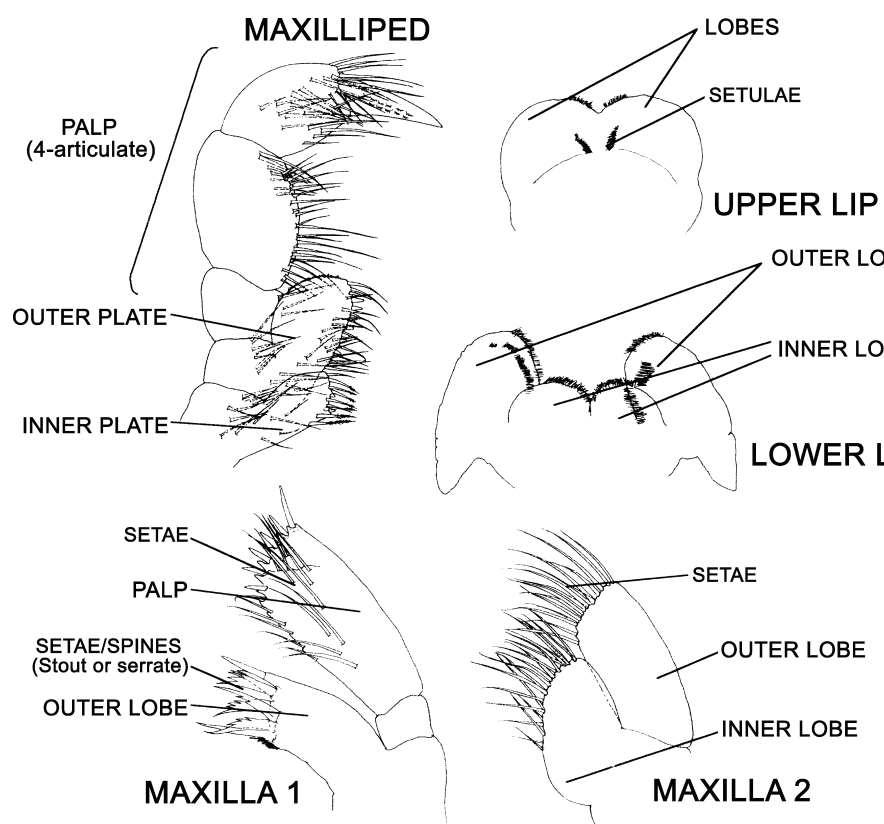

MAXILLA 1

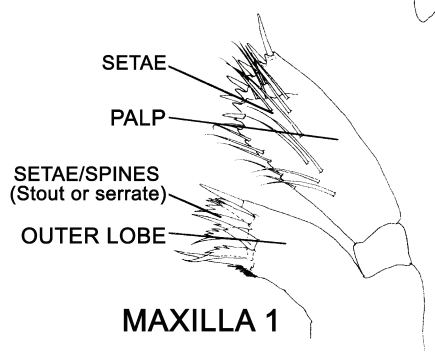

sieving the sediment, caprellids were separated from sediment by eluting, forcing water through the sediment and allowing the small crustaceans to float to the surface. All samples were fixed in $95 \%$ ethanol.

The abundance of caprellids on different substrates was characterized using a qualitative scale: rare (1-10 individuals/sample), common (10-100 ind./sample) and very common (>100 ind./sample). Similarities among caprellid species based on ecological preferences were established by classification analysis. A similarity matrix for the classification was derived using the Bray-Curtis index (Bray \& Curtis, 1957). This index was chosen because it does not consider double absences. The UPGMA aggregation algorithm was used (Sneath \& Sokal, 1973). Similar classification analysis has been successfully used in other ecological studies working with qualitative scales as in the present study (Carballo et al., 1996; Guerra-García, 2001).

Trade winds influence the physical conditions around the island. These blow consistently between 15 and 20 knots from the southeast between mid-March and September each year (Keable, 1995). Therefore, the island has been traditionally considered to have leeward sites on the west coast and windward sites on the east coast. To determine if the composition of the Caprellidae community differed between sides of the island, the 13 stations sampled on SCUBA were selected for the analysis. Although the sampling of the Caprellidae was qualitative, approximately the same collecting effort (in time and number of samples) was made in all stations. Therefore, a matrix of presence/ absence of the caprellid species at each station was constructed. The affinities among stations on the basis of the caprellid community were established through cluster analysis using the UPGMA method and the Bray Curtis similarity index. To confirm the results of the cluster, an MDS analysis (non-metric multidimensional scaling) was used with the matrix. To test the ordination, the stress coefficient of Kruskal \& Wish (1978) was employed. Multivariate analyses (classification and ordination) were carried out using the program PC-ORD v.305 (McCune \& Mefford, 1997) and PRIMER package (Clarke \& Gorley, 2001)
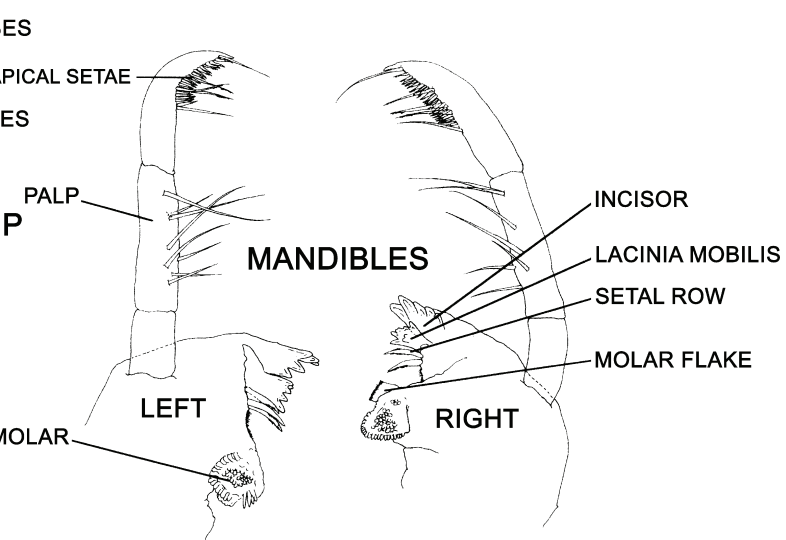

Fig. 4. Mouthparts of a generalized caprellid. 

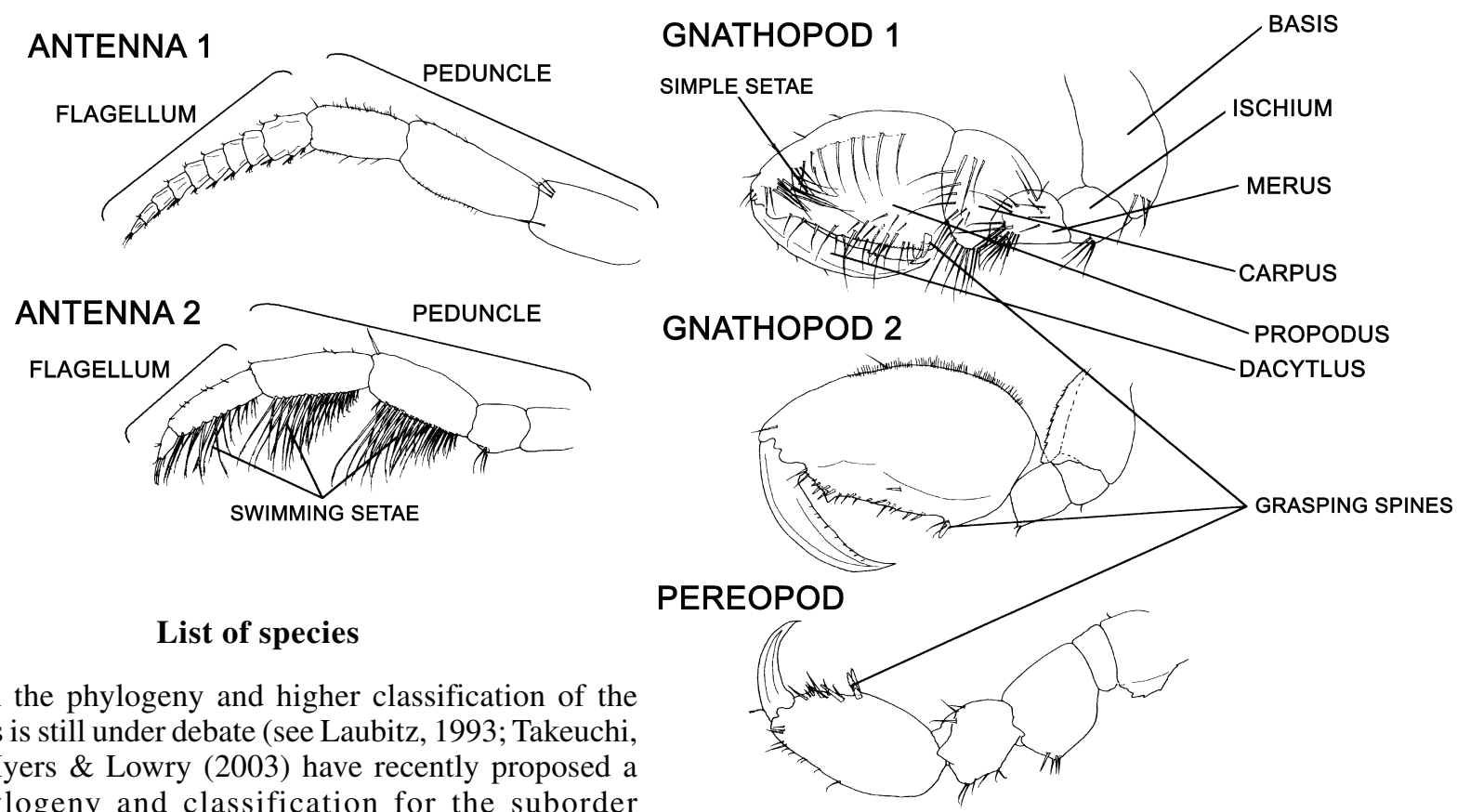

Although the phylogeny and higher classification of the caprellids is still under debate (see Laubitz, 1993; Takeuchi, 1993), Myers \& Lowry (2003) have recently proposed a new phylogeny and classification for the suborder Corophiidea Leach, 1814, comprising two infraorders, Corophiida and Caprellida, based on a hypothesis of the evolution of different feeding strategies. In their new classification, adopted here, the superfamily Caprelloidea includes five families: Caprellidae, Caprogammaridae, Cyamidae, Dulichiidae and Podoceridae. Caprellidae comprises three subfamilies: Caprellinae, Paracercopinae and Phtisicinae. The present study focuses on members of the Caprellidae. Figures 3-6 include drawings of a generalized caprellid showing the terminology used throughout the manuscript.

\section{Infraorder Caprellida Leach, 1814 \\ Superfamily Caprelloidea Leach, 1814 \\ Family Caprellidae Leach, 1814}

\section{Subfamily Phtisicinae Vassilenko, 1968}

Hircella berentsae n.sp. (Figs 7-11)

Hircella cornigera (Haswell, 1879) (Fig. 12)

Jigurru vailhoggett n.gen., n.sp. (Figs 13-17)

Mayericaprella arimotoi n.gen., n.sp. (Figs 18-22)

Metaproto novaehollandiae (Haswell, 1880) (Fig. 23)

Perotripus keablei $\mathrm{n} . \mathrm{sp}$. (Figs 24-27)

Protogeton inflatus Mayer, 1903 (Fig. 28)

Pseudoprellicana johnsoni n.gen., n.sp. (Figs 29-32)

Pseudoproto fallax Mayer, 1903 (Fig. 33)

Quadrisegmentum lowryi n.sp. (Figs 34-38)

Quadrisegmentum triangulum Hirayama, 1988 (Fig. 39)

\section{Subfamily Caprellinae Leach, 1814}

Aciconula australiensis Guerra-García, 2004 (Fig. 40)

Caprella danilevskii Czerniavskii, 1868 (Fig. 41)

Caprella penantis Leach, 1814 (Fig. 42)

Hemiaegina minuta Mayer, 1890 (Fig. 43)

Metaprotella sandalensis Mayer, 1898 (Fig. 44)

Orthoprotella australis (Haswell, 1880) (Fig. 45)

Orthoprotella mayeri Barnard, 1916 (Fig. 46)

Orthoprotella pearce n.sp. (Figs 47-51)

Paracaprella sp. (Fig. 52)

Protella similis Mayer, 1903 (Fig. 53)

Pseudaeginella biscaynensis McCain, 1968 (Fig. 54)

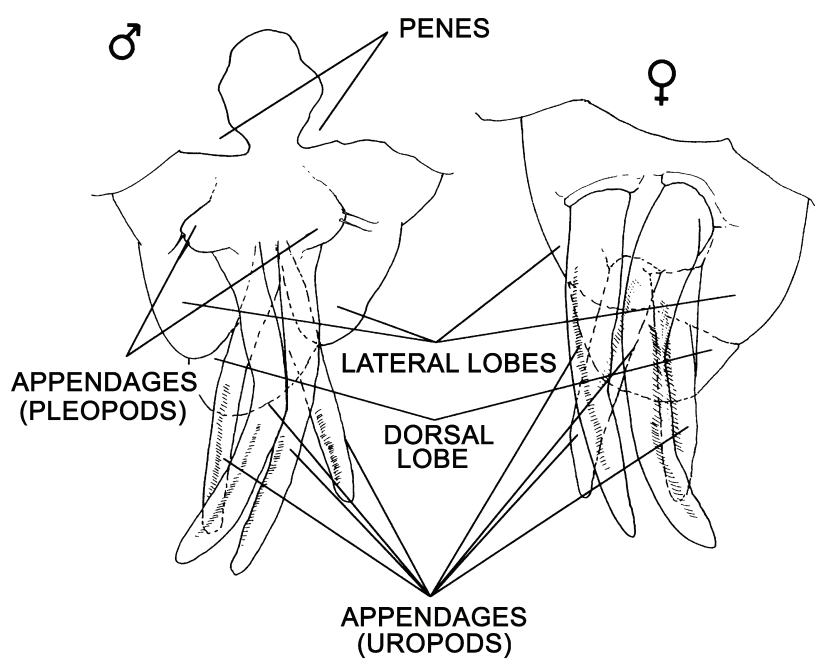

Fig. 5. Antennae, gnathopods and pereopod of a generalized caprellid.

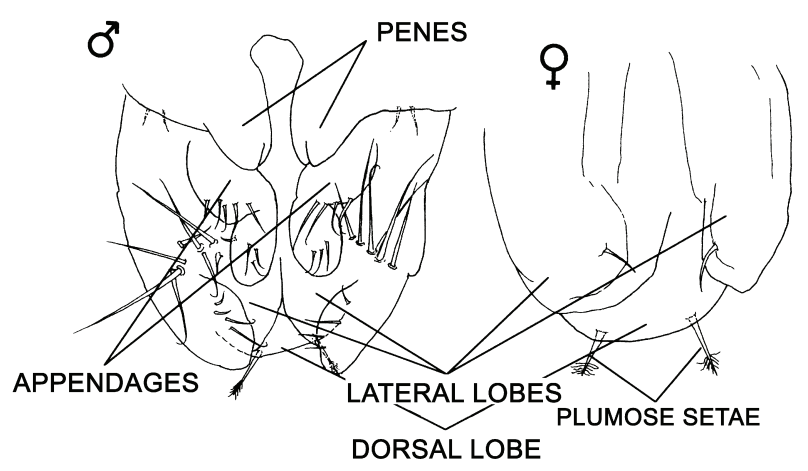

Fig. 6. Abdomen of generalized caprellids. 


\section{Key to the species of Caprellidae from the Great Barrier Reef and adjacent localities}

This key can be used without dissection but should be used in conjunction with Figs 3-6

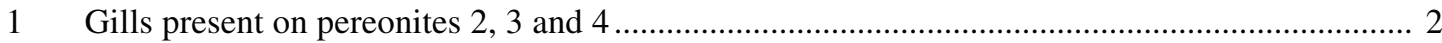

Gills present on pereonites 3 and 4, absent on pereonite 2 ................................................ 10

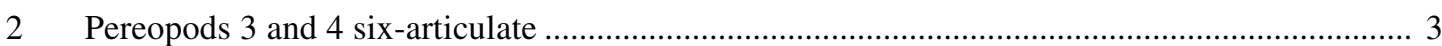

Pereopods 3 and 4 absent or reduced to a tiny article ................................................................ 6

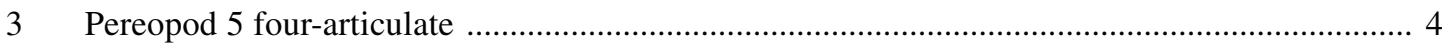

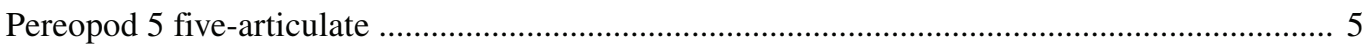

4 Antenna 1 clearly shorter than the body. Pereopods 3 and 4 shorter than pereonites 3 and 4 combined. Propodus of the male gnathopod

2 with a triangular projection

Quadrisegmentum triangulum (Fig. 39)

— Antenna 1 as long as body. Pereopods 3 and 4 longer than pereonites 3 and 4 combined. Propodus of the male gnathopod 2 without triangular projection Quadrisegmentum lowryi (Figs 34-38)

5 Abdomen with a pair of appendages Metaproto novaehollandiae (Fig. 23)

Abdomen without appendages Pseudoproto fallax (Figs 33)

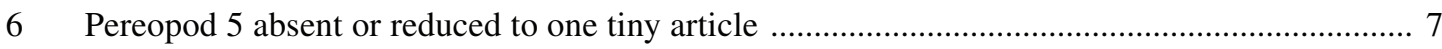

— Pereopod 5 present, three to six-articulate ……................................................................... 8

7 Body smooth, without acute dorsal projections ........................... Hircella berentsae (Figs 7-11)

Body with acute dorsal projections Hircella cornigera (Fig. 12)

8 Pereopods 3 and 4 reduced to one tiny article. Flagellum of antenna 12 -articulate. Body geniculate Perotripus keablei (Figs 24-27)

- Pereopod 3 and 4 absent. Flagellum of antenna 1 more than 2articulate. Body not geniculate 9

9 Pereonite 3 with a pair of well-developed projections ...... Mayericaprella arimotoi (Figs 18-22) Pereonite 3 without projections Jigurru vailhoggett (Figs 13-17)

10 Pereopods 3 and 4 six-articulate Protogeton inflatus (Fig. 28)

— Pereopods 3 and 4 absent or reduced to one or two articles

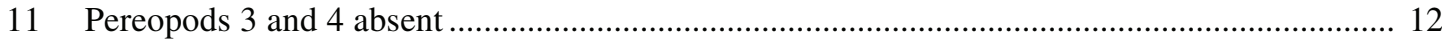

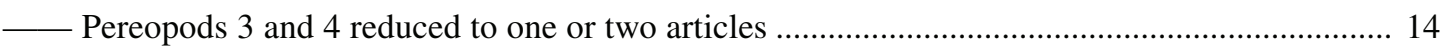

12 Pereopod 5 3-articulate ............................................. Pseudoprellicana johnsoni (Figs 29-32)

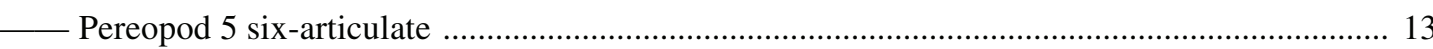

13 Head with a well-developed rostrum ................................................. Caprella penantis (Fig. 42)

Head with a small rostrum ............................................................ Caprella danilevskii (Fig. 41)

14 Pereonites 6 and 7 fused ..................................................... Metaprotella sandalensis (Fig. 44)

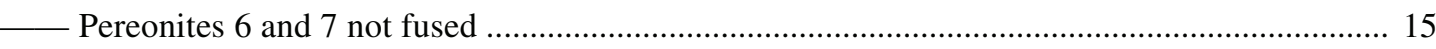

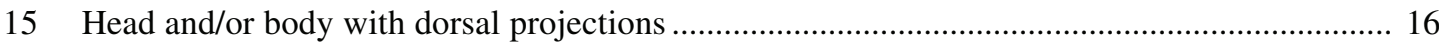

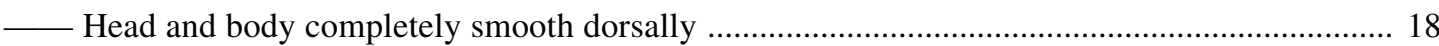

16 Pereonite 4 2-articulate

Aciconula australiensis (Fig. 40)

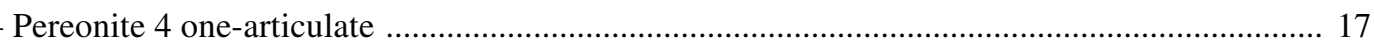

17 Head with two acute projections. Body smooth ........................ Orthoprotella australis (Fig. 45)

— Head with a single acute projection. Body with numerous rounded projections Pseudaginella biscaynensis (Fig. 54) 
18 Pereopods 3 and 4 2-articulate

Pereopods 3 and 4 one-articulate

19 Pereopods 3 and 4 minute, shorter than half length of gills Paracaprella sp. (Fig. 52)

Pereopods 3 and 4 longer than half length of gills Orthoprotella mayeri (Fig. 46)

20 Suture between head and pereonite 1 absent. Pereonite 2 with acute ventral projection between gnathopod 2

_ Suture between head and pereonite 1 present. Pereonite 2 without acute ventral projection.

21 Peduncle of antenna 1 distinctly longer than half body length Protella similis (Fig. 53)

Peduncle of antenna 1 about $1 / 3$ body length Orthoprotella pearce (Figs 47-51)

\section{Systematic account}

\section{Subfamily Phtisicinae Vassilenko, 1968}

\section{Hircella Mayer, 1882}

\section{Hircella berentsae n.sp.}

Figs 7-11

Type material. HOLOTYPE $\widehat{\delta}$, AM P61610, outer slope, W of "Yoshin Maru Iwaki”, Elizabeth Reef, Australia, 29 $57.2^{\prime}$ S $159^{\circ} 01.2^{\prime} \mathrm{E}$, coral rubble, 8 24 m, St 30, J.K. Lowry \& R.T. Springthorpe, 12 Dec 1987. PARATYPES: 1 , , AM P61611, type locality; $2 \delta^{\dagger} \delta, 3 ㅇ$ 으, AM P61612, type locality.

Additional material examined. 1 juvenile AM P61653 (QLD 980);

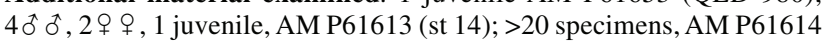
(st 21); 3 우 ㅇ, AM P61615 (st 30); 2 우 어, AM P61616 (st 36); 2 우 ㅇ, AM P61617 (st 43).

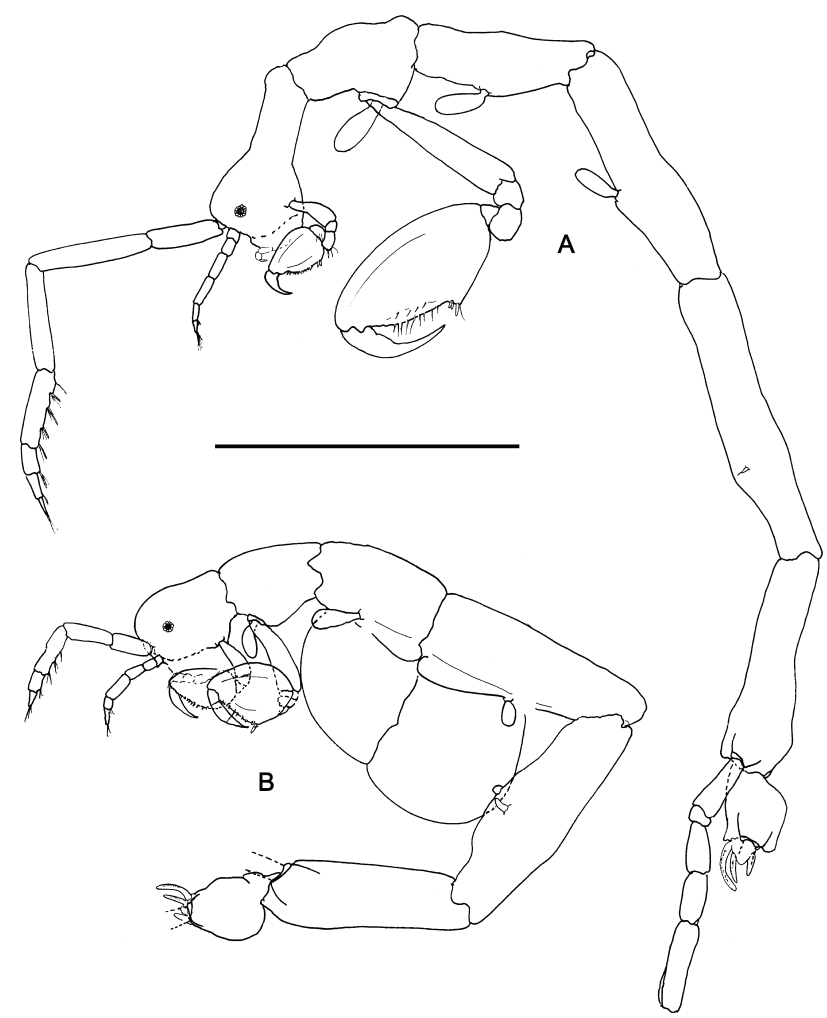

Fig. 7. Hircella berentsae n.sp. Lateral view. (A) holotype male (AM P61610); (B) paratype female (AM P61611). Scale: $1 \mathrm{~mm}$.
Etymology. This species is named after Penny Berents, Australian Museum, for her kindness and hospitality during my stay at the Australian Museum, and for facilitating the present study.

Diagnosis. Body smooth dorsally. Gills on pereonites 2-4. Antenna 1 shorter than half of the body. Distal article of the mandibular palp with 3-4 setae. Pereopods 3 and 4 absent. Pereopod 5 uniarticulate, present in males and females. Abdomen with two pairs of uniarticulate abdominal appendages.

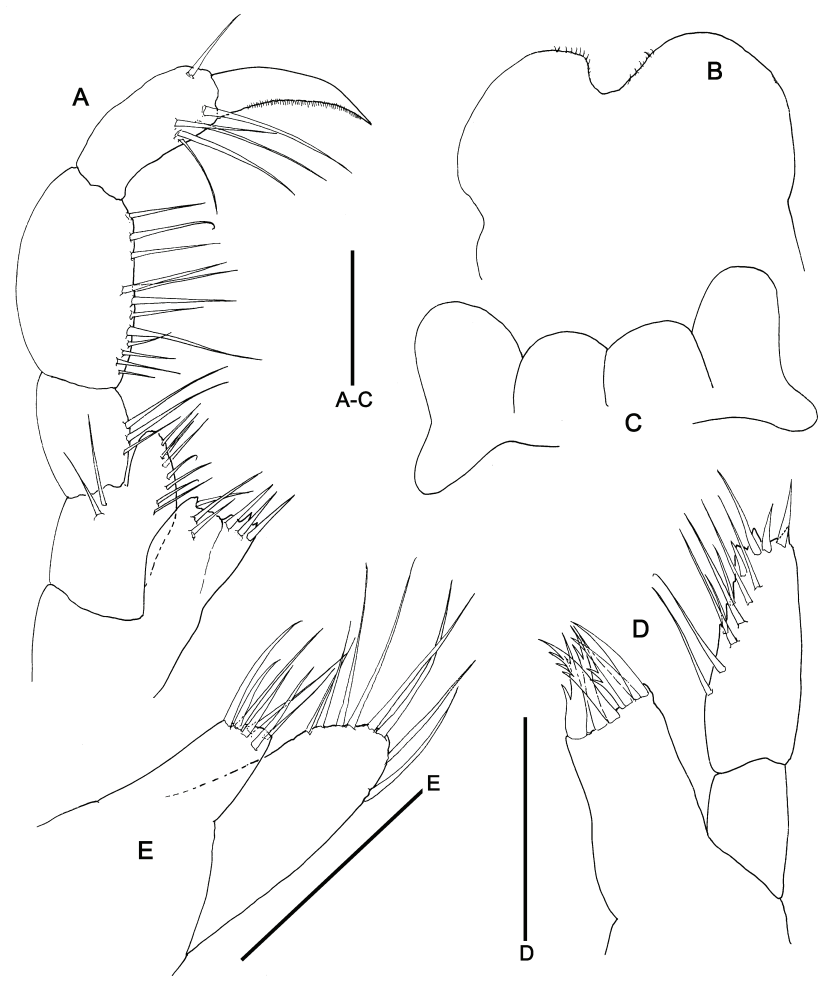

Fig. 8. Hircella berentsae n.sp. Holotype male (AM P61610). $(A)$ maxilliped; $(B)$ upper lip; $(C)$ lower lip; $(D)$ maxilla $1 ;(E)$ maxilla 2. Scales $0.05 \mathrm{~mm}$. 

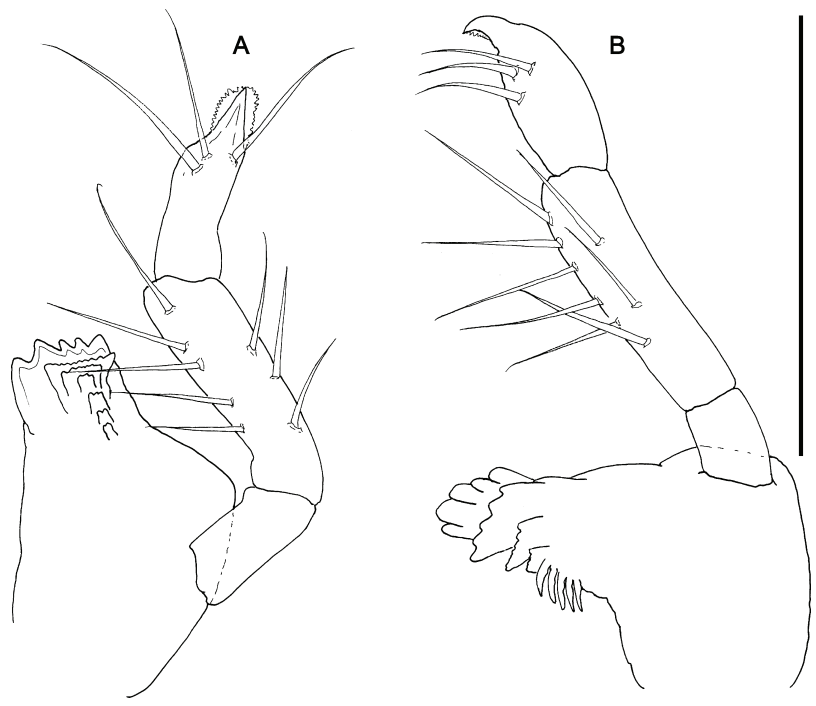

Fig. 9. Hircella berentsae n.sp. Holotype male (AM P61610). $(A)$ right mandible; $(B)$ left mandible. Scale: $0.1 \mathrm{~mm}$.

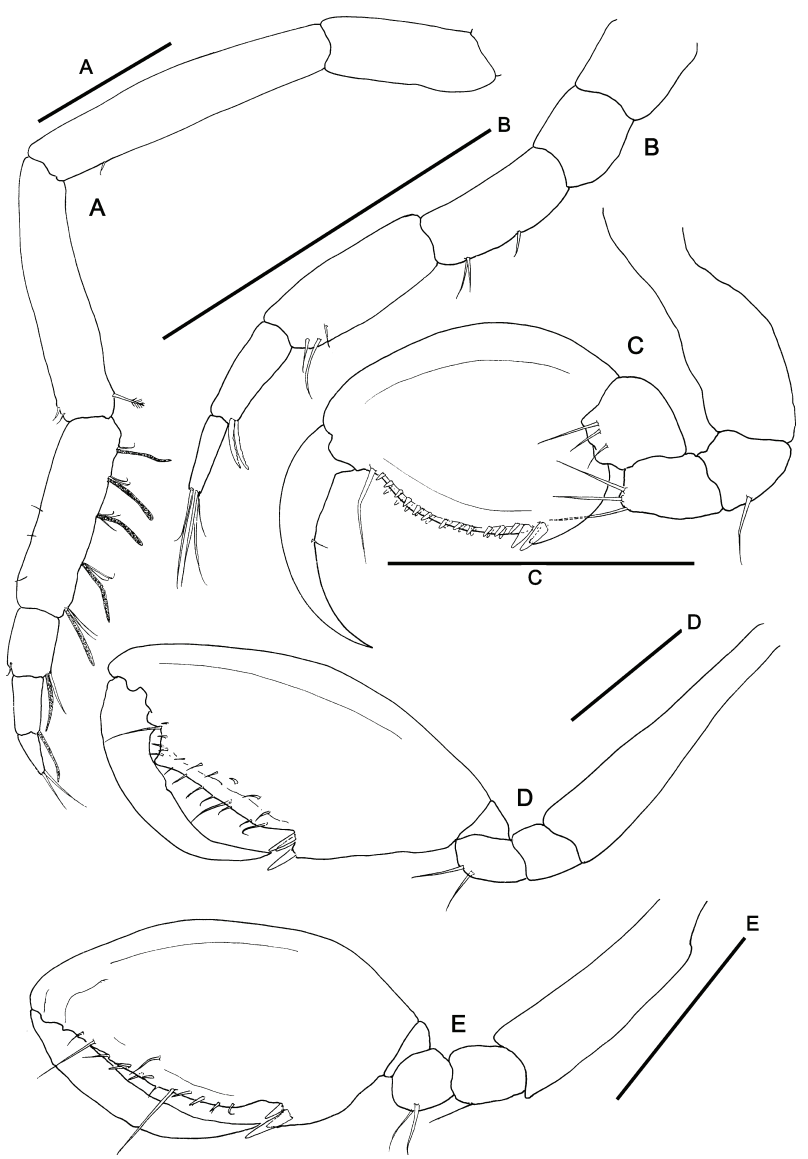

Fig. 10. Hircella berentsae n.sp. $(A-D)$ holotype male (AM P61610). (A) antenna 1; $(B)$ antenna 2; $(C)$ gnathopod $1 ;(D)$ gnathopod 2; $(E)$ paratype female (AM P61611) gnathopod 2. Scales $0.2 \mathrm{~mm}$.

\section{Description}

Holotype male. • Body length $3.7 \mathrm{~mm}$. - Lateral view (Fig. 7A). Body dorsally smooth. Head rounded. Eyes small. Pereonite 1 fused with head, suture not present; pereonites 2-5 increasing in length; pereonite 7 shortest. $\bullet$ Gills (Fig.
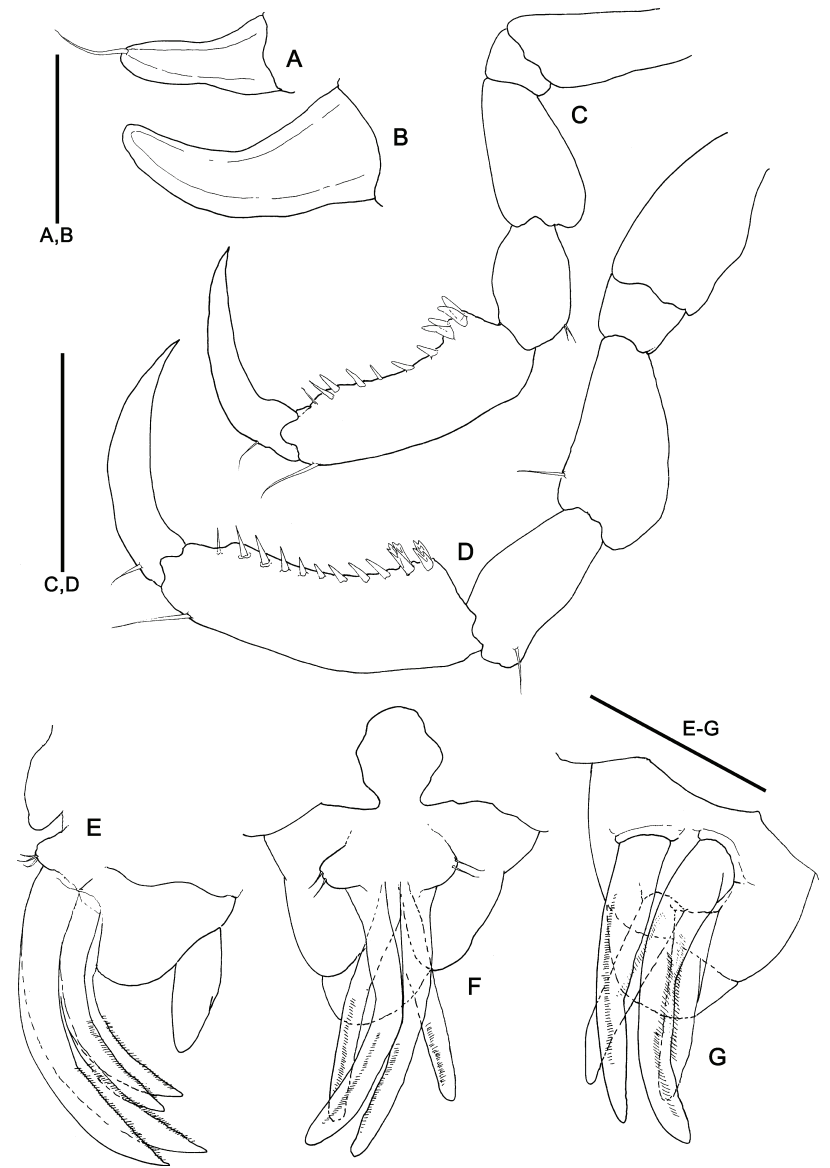

Fig. 11. Hircella berentsae n.sp. $(A, C-F)$ holotype male (AM P61610); $(B, G)$ paratype female (AM P61611). $(A, B)$ pereopod $5 ;(C)$ pereopod $6 ;(D)$ pereopod $7 ;(E)$ abdomen (lateral view); $(F, G)$ abdomen (ventral view). Scales: A,B: $0.2 \mathrm{~mm}$; C,D: 0.3 $\mathrm{mm} ; \mathrm{E}-\mathrm{G}: 0.1 \mathrm{~mm}$.

7A). Present on pereonites 2-4, oval, length about two times width. Gills on pereonite 4 slightly shorter than those on pereonite 2 and 3. - Mouthparts. Upper lip (Fig. 8B) symmetrically bilobed, slightly pubescent apically. Mandibles (Fig. 9A,B) with 3-articulate palp; distal article of palp with three apical setae; second article with eight simple setae; mandibular molar absent; left mandible (Fig. 9B) with 5-toothed incisor, lacinia mobilis 5-toothed followed by a row of minutely serrated plates decreasing in size; incisor of right mandible (Fig. 9A) 5-toothed, lacinia mobilis deeply serrate, followed by a row of minutely serrate plates; molar flake absent. Lower lip (Fig. 8C) with inner lobes well demarcated; inner and outer lobes without setulae. Maxilla 1 (Fig. 8D) outer lobe with six robust setae, serrate laterally; distal article of palp with six apical setae and row of six setae medially. Maxilla 2 (Fig. 8E) inner lobe rectangular with seven setae distally; outer lobe oval, twice as long as inner lobe, with eight apical setae. Maxilliped (Fig. 8A) inner plate rectangular with six setae; outer plate smaller than the inner plate, with setae; palp four-articulate; dactylus with a row of setulae. Antennae. Antenna 1 (Fig. 10A) robust, about one-third of body length; flagellum four-articulate. Antenna 2 (Fig. 10B) about onethird length of antenna 1 ; swimming setae absent; flagellum 2-articulate. • Gnathopods. Gnathopod 1 (Fig. 10C) basis 
as long as ischium, merus and carpus combined; propodus oval, length about 1.2 times width, palm with pair of grasping spines proximally and two rows of smaller spines along palm; dactylus robust and curved, with short setae medially. Gnathopod 2 (Fig. 10D) inserted on the posterior half of pereonite 2; basis as long as pereonite 2; ischium rectangular; merus rounded; carpus short and triangular; propodus rectangular, about 1.2 times as long as basis; palm with three grasping spines proximally and distal projection; dactylus curved and narrowed distally, smooth. Pereopods. Pereopod 5 (Fig. 11A) extremely reduced, with distal seta. Pereopods 6 and 7 (Fig. 11C,D) robust; basis without carina, ischium short and rectangular; propodus palm with two pairs of robust spines proximally and a row of smaller spines along occlusal margin. Penes (Fig. 11E,F) situated laterally, length about 1.2 times width. $\bullet$ Abdomen (Fig. 11E,F) with pair of small projections, each with two setae distally (probably vestigial pleopods), two pairs of long uniarticulate appendages (uropods), and a single dorsal lobe.

Paratype female. Body length $3.2 \mathrm{~mm}$. Antenna 1 flagellum 3-articulate (Fig. 7B). Propodus palm of gnathopod 2 (Fig. 10E) without distal projection. Oostegites not setose (Fig. 7B). Pereopod 5 (Fig. 11B) twice as long as in male, without setae and curved. Abdomen (Fig. 11G) without small projections.

Remarks. Mayer (1882) established the genus Hircella mainly on the basis of the absence of pereopod 5. The genus Liriarchus Mayer, 1912 is also characterized by the absence of pereopod 5 in males or extremely reduced in females. However, Hircella and Liriarchus can be differentiated by the abdomen: two pairs of appendages are present in Hircella instead of one pair in Liriarchus. The present specimens collected from Queensland are assigned to Hircella on the basis of the presence of two pairs of appendages in the abdomen. Hircella presently includes $H$. berentsae n.sp., H. cornigera (Haswell, 1879), and $H$. inermis Guerra-García \& Takeuchi, 2004, described from Tasmanian waters. Hircella berentsae n.sp. differs from $H$. cornigera, the type species of the genus, mainly on the basis of the following features: (1) pereopod 5 is present in females of $H$. berentsae but absent in females of $H$. cornigera; (2) the body is smooth in $H$. berentsae but provided with large dorsal acute projections on pereonites 3-5 in H. cornigera; and (3) antenna 1 is clearly shorter than half the body length in $H$. berentsae but longer in $H$. cornigera. Although $H$. berentsae n.sp. is closer to $H$. inermis, several constant differences indicate that both are valid species: (1) the adult body length of $H$. inermis is about $10 \mathrm{~mm}$ in contrast to $3-4 \mathrm{~mm}$ in $H$. berentsae; (2) pereopod 5 is absent in males of $H$. inermis but present in males of $H$. berentsae; (3) the antenna 1 flagellum is eightarticulate in males of $H$. inermis but four-articulate in $H$. berentsae; (4) the first pair of abdominal appendages is 2articulate in $H$. inermis but one-articulate in $H$. berentsae; (5) the distal article of the mandibular palp bears six apical setae in H. inermis and 3 or 4 in $H$. berentsae.

Most morphological characters of $H$. berentsae are constant in all specimens examined. Nevertheless, the number of apical setae in the distal article of the mandibular palp varies, being three or four depending on the specimens.

Distribution. Elizabeth and Middleton Reefs, Tasman Sea, and Freshwater Bay, Queensland.

\section{Hircella cornigera (Haswell, 1879)}

Fig. 12

Caprella cornigera Haswell, 1879: 347-348, pl. 23: fig. 5.

Hircella cornigera Haswell, 1885: 999; Mayer, 1890: 16-17, pl. 5: figs. 10-11, pl. 6: figs 3-22; Mayer, 1903: 31-32; Stebbing, 1910: 652 .

Material examined. 10 , 1 ㅇ, AM P47048, Boat Rock, North Stradbroke Island, Queensland, $27^{\circ} 25.21^{\prime} \mathrm{S} 153^{\circ} 33.28^{\prime} \mathrm{E}$, bryozoans, hydrozoans and brown algae, $28 \mathrm{~m}, 21.8^{\circ} \mathrm{C}$, R.T. Springthorpe, 3 Jun 1993.

Remarks. In H. cornigera, pereopod 5 is reduced to a tiny article in males, and is absent in females. The type material of Hircella cornigera is lost (Springthorpe \& Lowry, 1994).

Distribution. Previously known only from the type locality, Port Jackson, New South Wales, Australia (McCain \& Steinberg, 1970); a new record for Queensland, Australia.

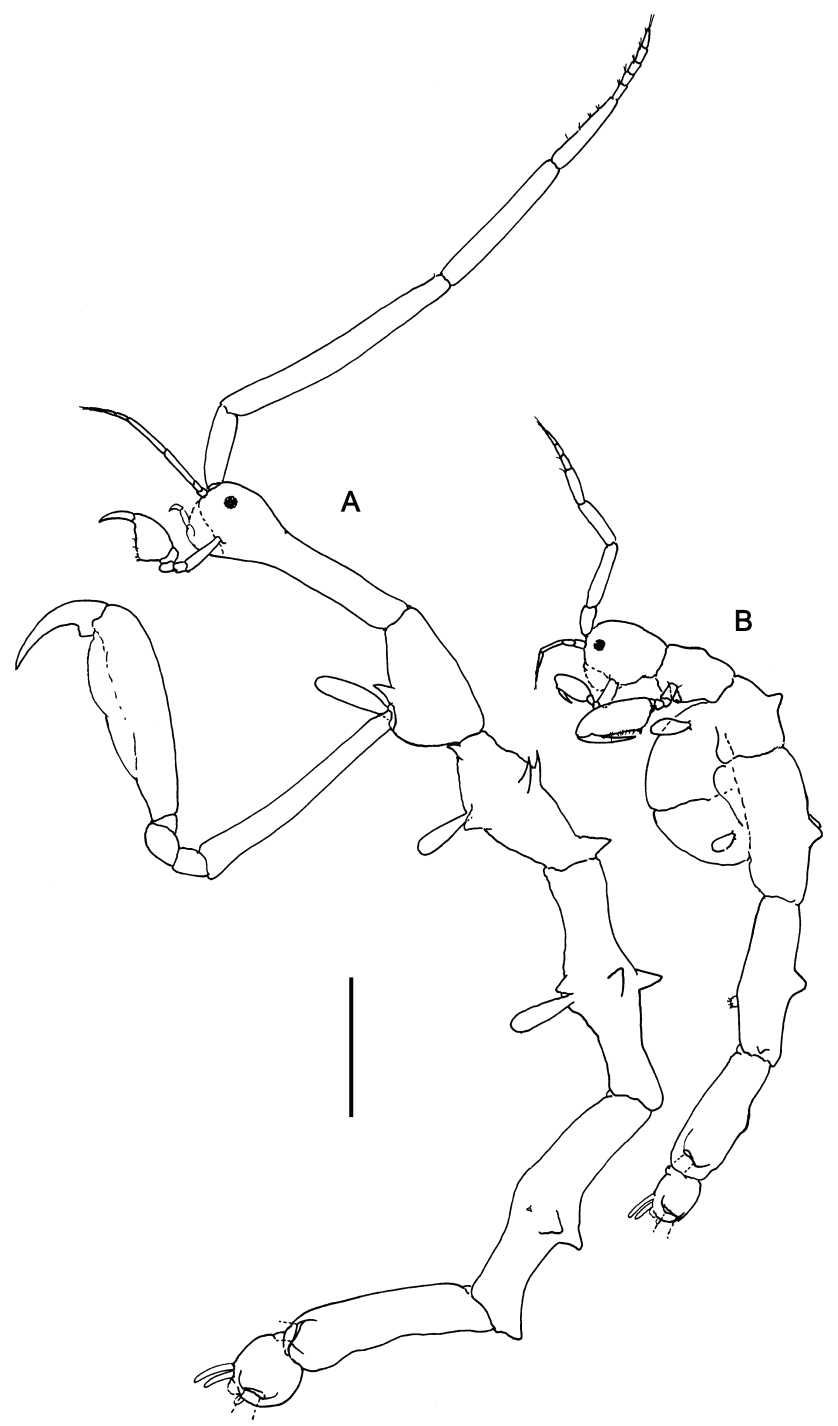

Fig. 12. Hircella cornigera (Haswell, 1879). Lateral view. (A) male; (B) female. (AM P47048). Scale: $1 \mathrm{~mm}$. 


\section{Jigurru n.gen.}

Diagnosis. Antenna 2 flagellum 2-articulate. Gills present on pereonites 2-4. Pereopods 3 and 4 absent. Pereopod 5 3 -articulate, with basal article almost divided at midlength. Pereopods 6 and 7 six-articulate; carpus and propodus with a row of large spines along palm. Mandibular palp 3articulate. Molar absent. Inner plates of maxilliped partially fused. Abdomen with two pairs of appendages.

Etymology. Named "Jigurru", the name given to Lizard Island by the traditional custodians of the island, the Dingaal people. Gender: masculine.

\section{Type species. Jigurru vailhoggett $\mathrm{n} . \mathrm{sp}$.}

Remarks. The new genus Jigurru shares some characters with Caprellina (Nicolet, 1849) and Prellicana Mayer, 1903. Jigurru appears to be closer to Caprellina than Prellicana on the basis of the presence of three pairs of gills, reduced pereonite 5 and two pairs of appendages in the abdomen. Nevertheless, the small size, general features of the body, the incomplete articulation of the basal article in the pereopods 5 , the shape of pereopods 6 and 7 , and the partially fused inner plates of the maxilliped strongly resemble Prellicana. Prellicana, however, has only two pairs of gills and one pair of abdominal appendages whereas Jigurru possesses three pairs of gills and two pairs of abdominal appendages.

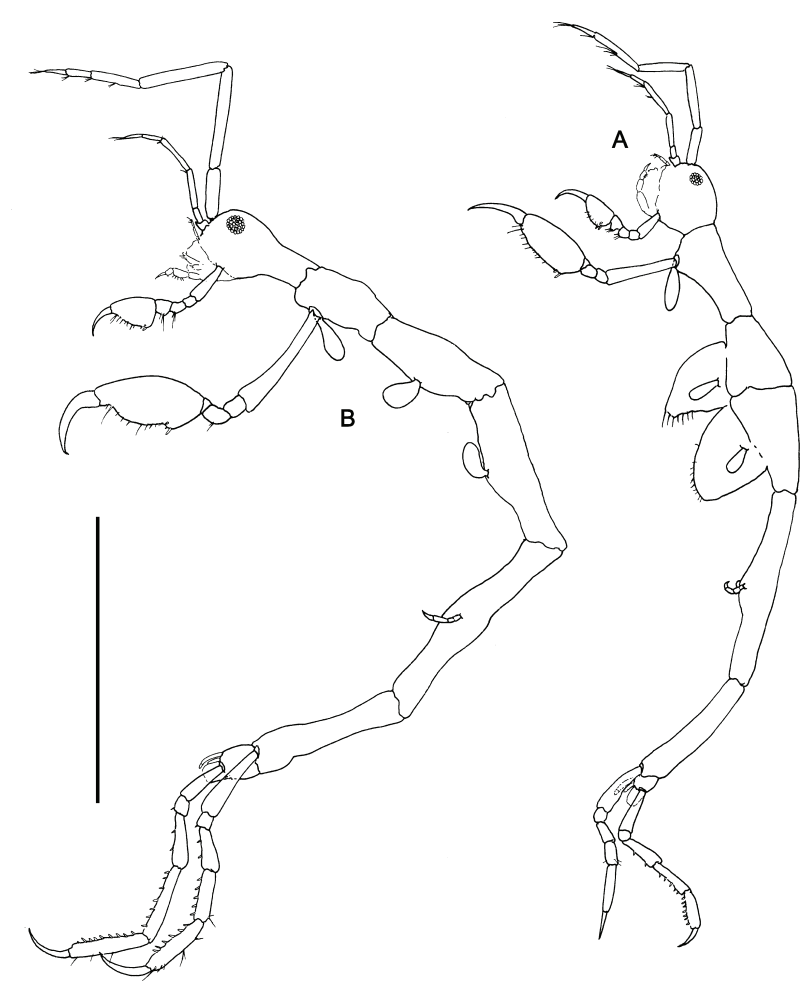

Fig. 13. Jigurru vailhoggett n.gen., n.sp. Lateral view. (A) paratype female (AM P61745); (B) holotype male (AM P61744). Scale: 1 $\mathrm{mm}$.

\section{Jigurru vailhoggett n.sp.}

Figs $13-17$

Type material. HolotyPe ô, AM P61744, Coconut Beach, Lizard Island, Queensland, Australia, $14^{\circ} 40^{\prime} \mathrm{S} 145^{\circ} 28^{\prime} \mathrm{E}$, dead thick branching hard coral encrusted with calcareous red algae and filamentous algal turf, 8 m, QLD 1475, J.M. Guerra-García \& S.J. Keable, 8 Oct 2001. PARATYPES: $20 \hat{\sigma}, 1$, AM P61745, type locality.

Etymology. The specific name is derived from "Vail" and "Hoggett" to dedicate the species to Lyle Vail and Anne Hoggett, directors of the Lizard Island Research Station for their help and kindness during the field study at Lizard Island; used as a noun in apposition.

Diagnosis. As for the genus.

\section{Description}

Holotype male. $\bullet$ Body length. $3.1 \mathrm{~mm}$. Lateral view (Fig. 13B). Body smooth without projections; head rounded; suture between head and pereonite 1 absent; pereonites 25 increasing in size respectively; pereonite 7 the shortest. - Gills (Fig. 13B). Present on pereonites 2-4, oval, length about 2 times width. - Mouthparts. Upper lip (Fig. 14B) symmetrically bilobed, lobes poorly demarcated, smooth apically. Mandibles (Fig. 15A,B) without molar; left mandible (Fig. 15B) with incisor 5-toothed, lacinia mobilis 5-toothed followed by a row of plates decreasing in size; right mandible (Fig. 15A) with incisor 5-toothed, lacinia mobilis with 2 teeth and serrate, followed by row of plates;

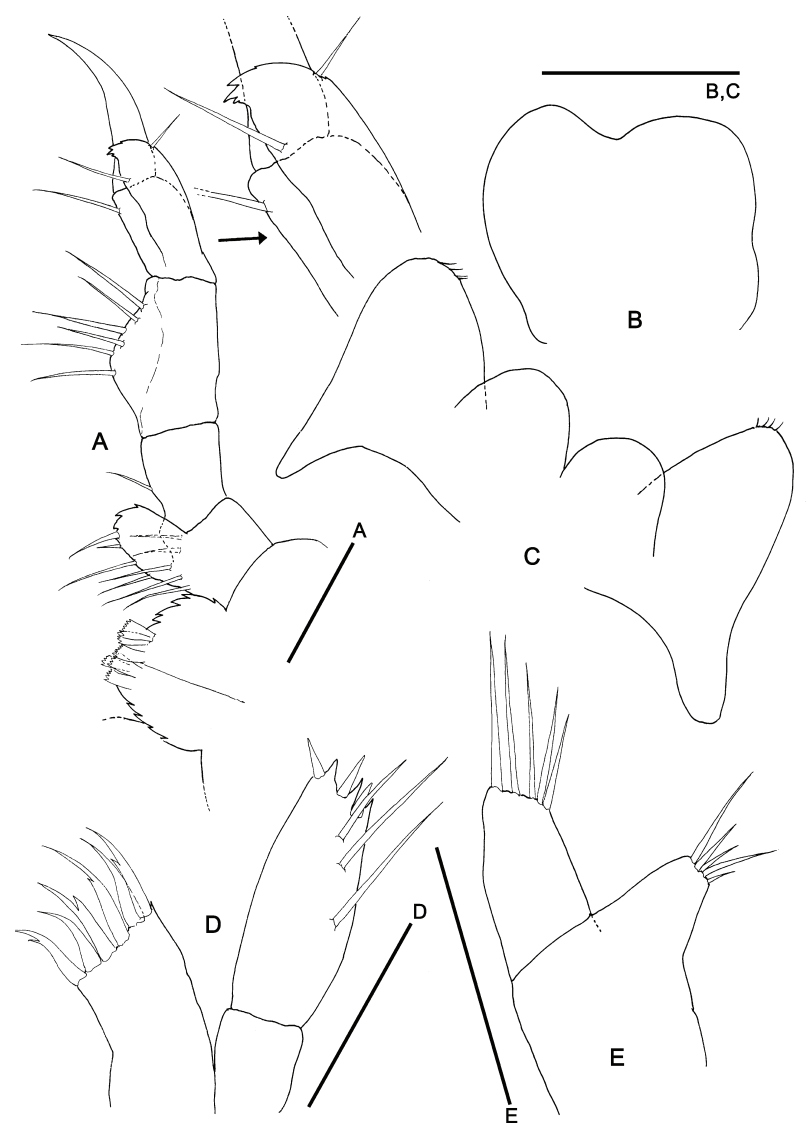

Fig. 14. Jigurru vailhoggett n.gen., n.sp. Holotype male (AM P61744). (A) maxilliped; $(B)$ upper lip; $(C)$ lower lip; $(D)$ maxilla $1 ;(E)$ maxilla 2. Scales $0.05 \mathrm{~mm}$. 


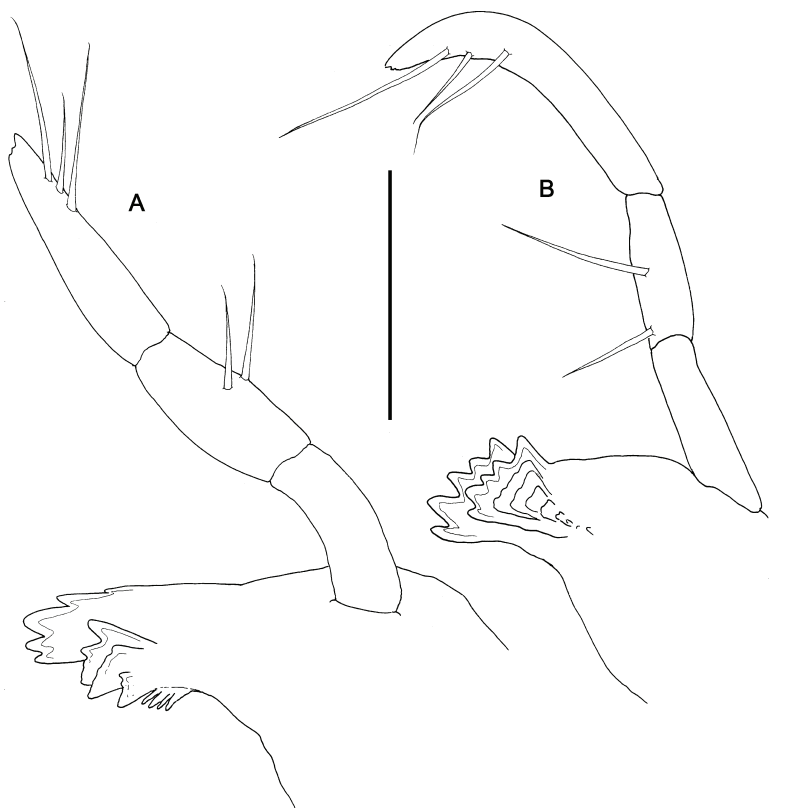

Fig. 15. Jigurru vailhoggett n.gen., n.sp. Holotype male (AM P61744). (A) right mandible; (B) left mandible. Scale: $0.05 \mathrm{~mm}$.

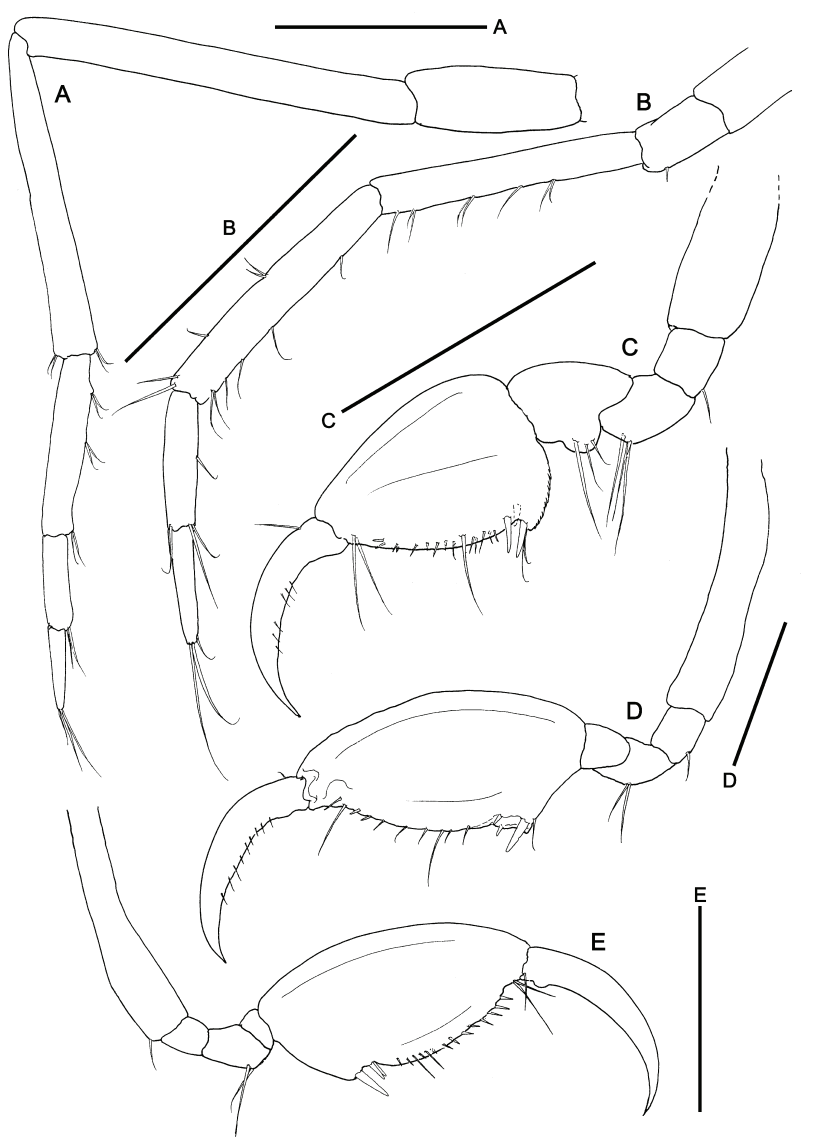

Fig. 16. Jigurru vailhoggett n.gen., n.sp. A-D, holotype male (AM P61744). (A) antenna 1; $(B)$ antenna 2; $(C)$ gnathopod 1; $(D)$ gnathopod 2; $(E)$ paratype female (AM P61745) gnathopod 2. Scales $0.2 \mathrm{~mm}$.

palp 3-articulate, second article with two setae, distal article with three setae (formula 1-x-1, being $\mathrm{x}=1$ ). Lower lip (Fig. 14C) with inner lobes well demarcated; outer lobes with some fine and short apical setae. Maxilla 1 (Fig. 14D) outer lobe with six robust and stout setae; distal article of palp

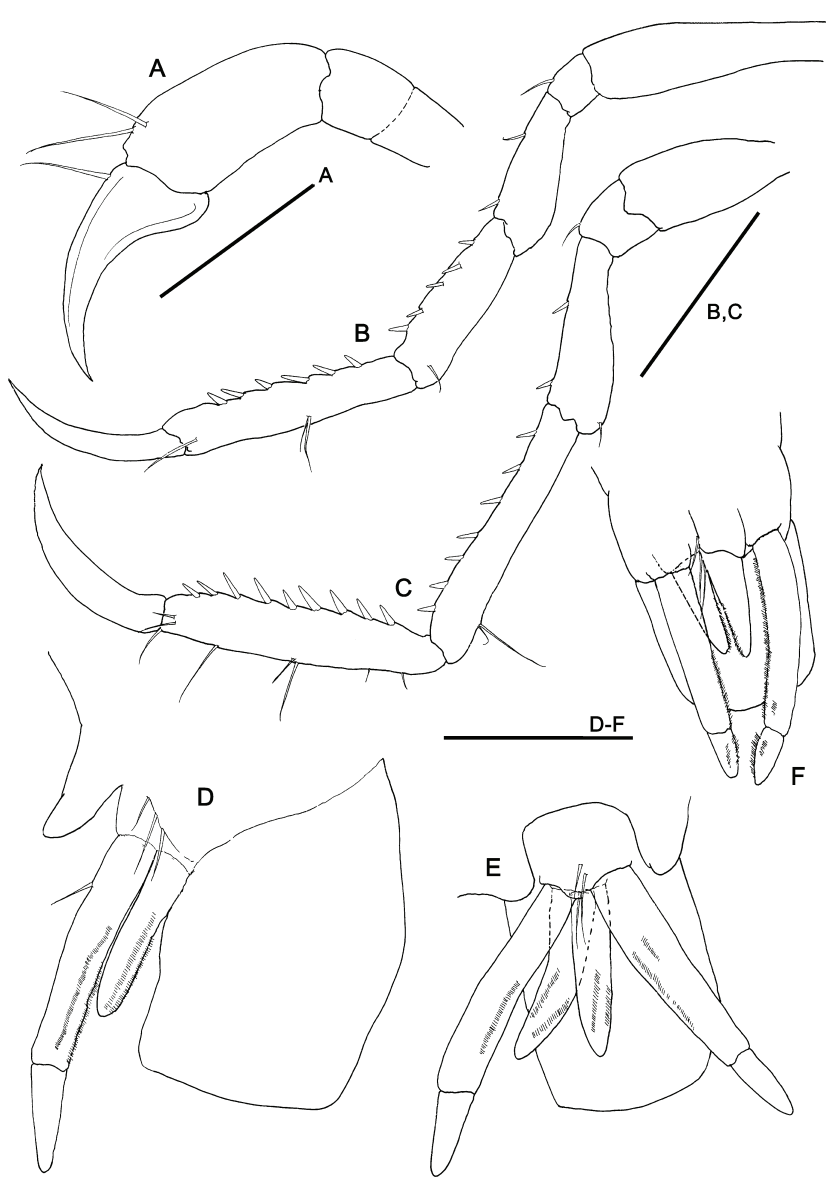

Fig. 17. Jigurru vailhoggett n.gen., n.sp. A-E, holotype male (AM P61744). (A) pereopod 5; $(B)$ pereopod 6; $(C)$ pereopod 7; $(D)$ abdomen (lateral view); $(E)$ abdomen (ventral view); $(F)$ paratype female (AM P61745) abdomen (ventral view). Scales: A,D-F: $0.05 \mathrm{~mm}$; B,C: $0.2 \mathrm{~mm}$.

with three setae and three teeth distally and row of three lateral setae. Maxilla 2 (Fig. 14E) inner lobe triangular with five setae; outer lobe rectangular with five setae. Maxilliped (Fig. 14A) inner plates almost fused, with a serrate margin and three apically serrate nodular setae; outer plate with seven simple setae and serration; palp four-articulate, article 2 laterally expanded, with six setae; article 3 with large rectangular projection emerging from the base, with two setae laterally, serrate distally. • Antennae. Antenna 1 (Fig. $16 \mathrm{~A}$ ) about $1 / 3$ of the body length; flagellum 3-articulate. Antenna 2 (Fig. 16B) a little shorter than the half of the antenna 1, sparsely setose; swimming setae absent; flagellum 2-articulate. - Gnathopods. Gnathopod 1 (Fig. 16C) basis as long as ischium, merus and carpus combined; ischium rectangular; merus rounded; propodus triangular, length about 1.5 times width, palm with three proximal grasping spines, grasping margin minutely denticulate on anterior half; dactylus elongate and curved, provided with long seta dorsally, and a row of short setae ventrally. Gnathopod 2 (Fig. 16D) inserted on the anterior part of pereonite 2; basis about 1.2 times as long as pereonite 2; ischium rectangular; merus rounded; carpus triangular; propodus oval, length about 2 times width, palm with three proximal grasping spines; dactylus curved, with row of short setae. Pereopods. Pereopods 3 and 4 absent (Fig. 13B). Pereopod 5 3-articulate (Fig. 17A), but basal article almost divided into two articles. Pereopods 6 (Fig. 17B) and 7 (Fig. 
17C), six-articulate, ischium with one seta, merus with two spines, carpus with five (pereopod 6) or seven (pereopod 7) spines along the palm, carpus with six (pereopod 6) or nine (pereopod 7) spines, dactylus smooth. - Penes (Fig. $17 \mathrm{D}, \mathrm{E})$ large, triangular, as long as wide, small suture present apically. Abdomen (Fig. 17D,E) with two pair of appendages and a large, prismatic dorsal lobe; first pair of appendages 2-articulate; second pair uniarticulate.

Paratype female. • Body length $2.2 \mathrm{~mm}$. Oostegites (Fig. 13A) scarcely setose. Gnathopod 2 (Fig. 16E) similar to male, but with dactylus slightly more elongate.

Remarks. The maxilliped of Jigurru vailhoggett n.sp. is close to the maxilliped of Prellicana minima Mayer, 1903 on the basis of the inner plates, being partially fused. However, the lateral expansion on article 2 and the welldeveloped projection on article 3 are present, so far, only in Jigurru vailhoggett $\mathrm{n} . \mathrm{sp}$ in the subfamily Phtisicinae.

Distribution. Lizard Island, Queensland.

\section{Mayericaprella n.gen.}

Diagnosis. Flagellum of antenna 2 2-articulate. Gills present on pereonites 2-4. Pereopods 3 and 4 absent. Pereopod 5 four-articulate. Pereopods 6 and 7 six-articulate; propodus with two pairs of proximal grasping spines. Mandibular palp 3-articulate. Molar absent. Abdomen with two pairs of 2articulate appendages.

Etymology. Mayericaprella is derived from "Mayer" and "Caprella" to dedicate the genus to P. Mayer for his valuable contributions to the knowledge of the Caprellidae during the last century. Gender: feminine.

\section{Type species. Mayericaprella arimotoi n.sp.}

Remarks. Mayericaprella n.gen. is close to Caprellina, especially to Caprellina bispinosa Müller, 1990. The general shape of the body, the structure of the antennae, the distribution of the gills, the mouthparts (especially the maxilliped) and the abdomen are similar to that of species of Caprellina. However, the gnathopods and pereopods are different, especially pereopod 5 which is four-articulate in the new genus and 2- or 3-articulate in Caprellina (2articulate in C. bispinosa and 3-articulate in C. longicollis and $C$. spiniger). The only other genus in the subfamily Phtisicinae with four-articulate pereopods 5 is Quadrisegmentum. Although Mayericaprella shares with Quadrisegmentum the presence of four-articulate pereopod 5, the genera differ chiefly in pereopods 3 and 4, being present in the latter and absent in former. The number of articles on pereopod 5 is an important phylogenetic character in the Phtisicinae because they show progressive changes in segmentation of the limb (Hirayama, 1988). At present, the number of articles in the pereopods distinguishes genera (Mayer, 1903; Arimoto, 1976). For instance, genera close to Caprellina, such as Hircella, have been erected mainly on the basis of one-articulate pereopod 5. Nevertheless, Müller (1990) assigned C. bispinosa (having a 2-articulate pereopod 5) to Caprellina (characterized by a 3 -articulate pereopod 5) instead of erecting a new genus for the species. Further study might show that $C$. bispinosa should be transferred to a different genus. The general morphology of Mayericaprella, with a four-articulate pereopod 5, is closer to Caprellina bispinosa with pereopod 52 -articulate, than to the remaining species of Caprellina with a 3articulate pereopod 5. Actually, the phylogenetic relationships among the species of the seemingly closely related genera Caprellina, Pseudocaprellina, Hircella and Liriarchus require study. The continuous gradient of variation in the characters of species of these genera makes generic distinctions difficult. A complete phylogenetic revision of the Caprellidae, necessary to address properly future taxonomic studies of this group, is required.

\section{Mayericaprella arimotoi n.sp.}

Figs 18-22

Type material. HolOTYPE ơ, AM P61561, outer slope, W of "Yoshin Maru Iwaki”, Elizabeth Reef, Australia, 29 $57.2^{\prime} \mathrm{S} 159^{\circ} 01.2^{\prime} \mathrm{E}$, coral rubble, 8-24 m, st 30, J.K. Lowry \& R.T. Springthorpe, 12 Dec 1987. PARATYPES: 19 , AM P61562, type locality; 19 , AM P61563, type locality; 1o , 2 우, AM P61565, reef flat near "Yoshin Maru Iwaki", Elizabeth Reef, Australia, 29 $57.2^{\prime} \mathrm{S} 159^{\circ} 01.2^{\prime} \mathrm{E}$, J.K Lowry \& R.T.

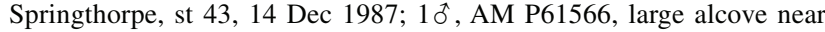
lagoon entrance, Sound dive site, Middleton Reef, Australia, 29²7.7'S $159^{\circ} 05.4^{\prime} \mathrm{E}, 6$ m, P. Hutchings \& I. Loch, st 7, 5 Dec 1987.

Etymology. The species is dedicated to I. Arimoto for his valuable taxonomic studies on the Caprellidae.

Diagnosis. As for the genus.

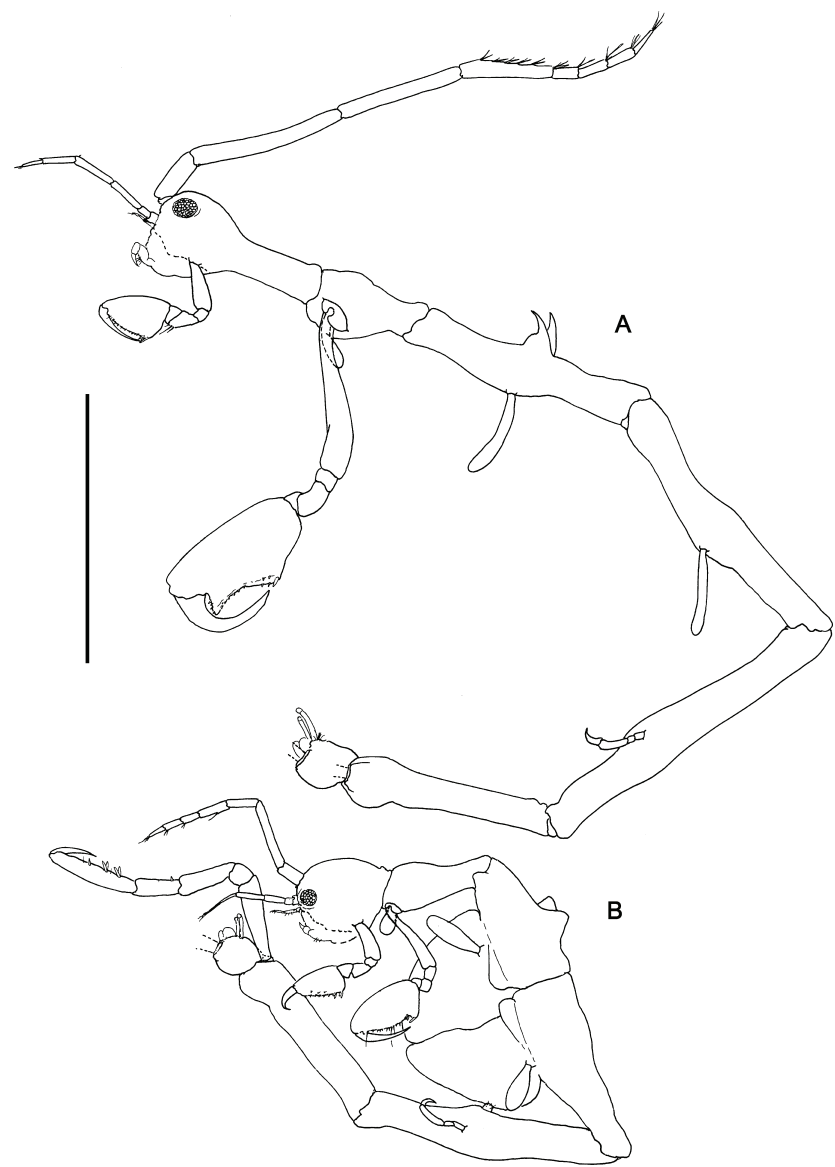

Fig. 18. Mayericaprella arimotoi n.gen., n.sp. Lateral view. $(A)$ holotype male (AM P61561); (B) paratype female (AM P61562). Scale: $1 \mathrm{~mm}$. 


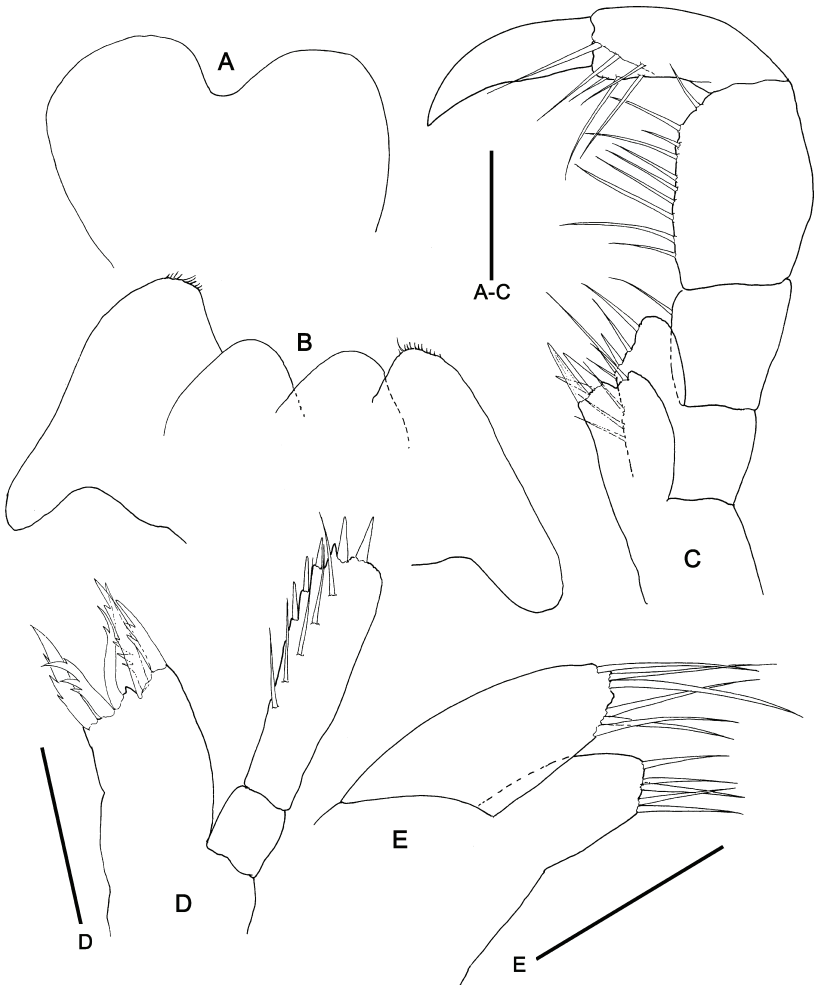

Fig. 19. Mayericaprella arimotoi n.gen., n.sp. Holotype male (AM P61561). (A) upper lip; $(B)$ lower lip; $(C)$ maxilliped; $(D)$ maxilla 1; $(E)$ maxilla 2 . Scales $0.05 \mathrm{~mm}$.
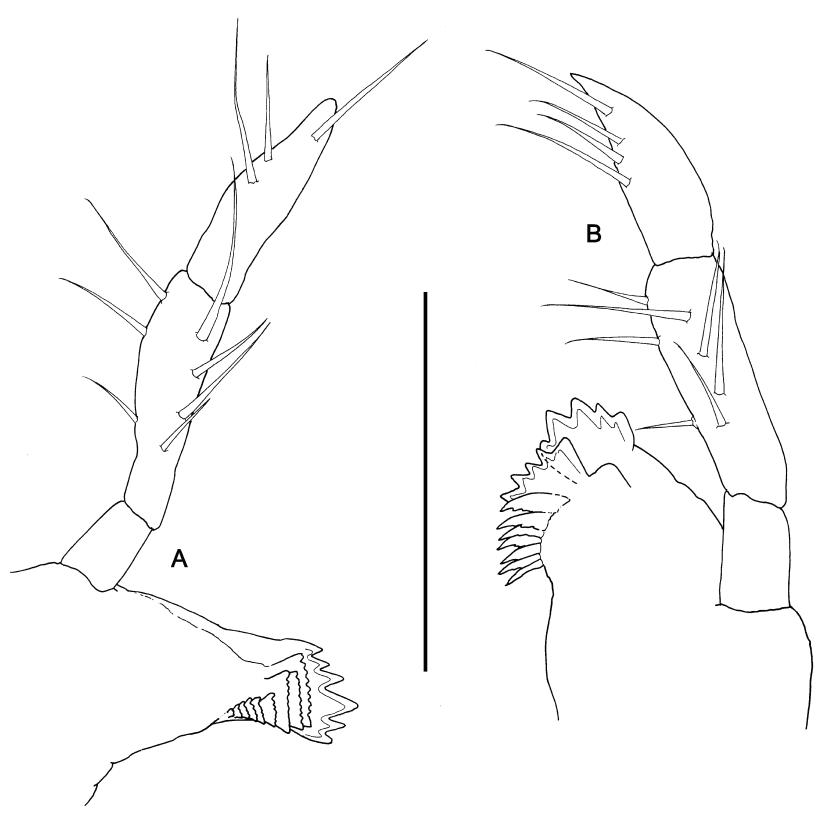

Fig. 20. Mayericaprella arimotoi n.gen., n.sp. Holotype male (AM P61561). (A) right mandible; $(B)$ left mandible mandible. Scale: $0.1 \mathrm{~mm}$.

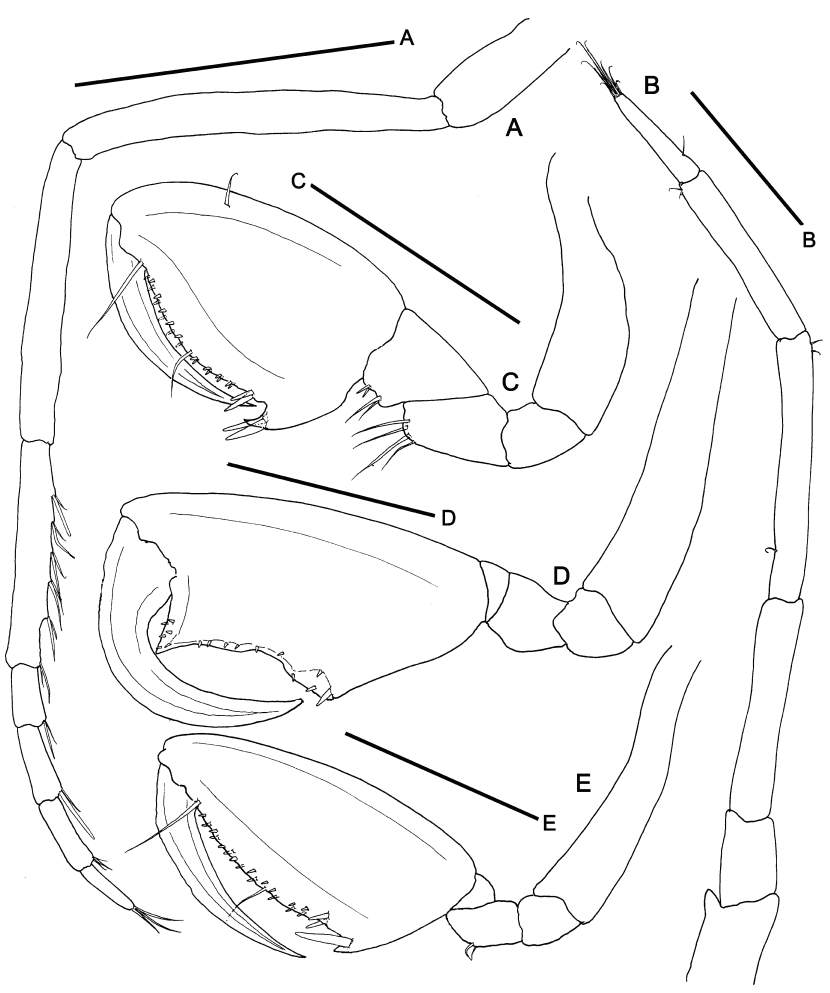

Fig. 21. Mayericaprella arimotoi n.gen., n.sp. A-D, holotype male (AM P61561). (A) antenna 1; $(B)$ antenna 2; $(C)$ gnathopod 1; $(D)$ gnathopod 2; $(E)$ paratype female (AM P61562) gnathopod 2. Scales: A: $0.5 \mathrm{~mm}$; B: $0.1 \mathrm{~mm}$; C,E: $0.2 \mathrm{~mm}$; D: $0.3 \mathrm{~mm}$.

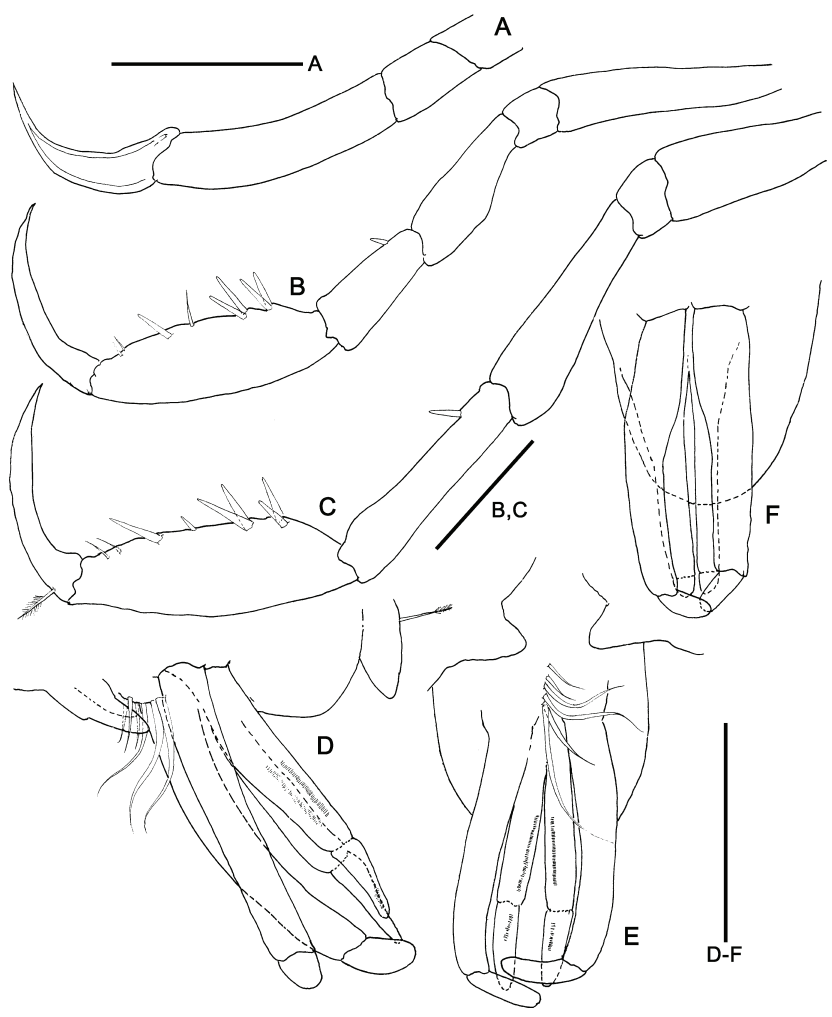

Fig. 22. Mayericaprella arimotoi n.gen., n.sp. $(A-E)$ holotype male (AM P61561). (A) pereopod 5; (B) pereopod 6; $(C)$ pereopod 7; $(D)$ abdomen (lateral view); $(E)$ abdomen (ventral view); $(F)$ paratype female (AM P61562) abdomen (ventral view). Scales $0.1 \mathrm{~mm}$. 


\section{Description}

Holotype male. • Body length. $5.2 \mathrm{~mm}$. - Lateral view (Fig. 18A). Body smooth except for a pair of acute projections on the middle of the pereonite 3; head rounded; suture between head and pereonite 1 absent; pereonites 2-5 increasing in size respectively; pereonite 7 the shortest. - Gills (Fig. 18A). Present on pereonites 2-4. Gills on pereonite 2 oval, 2.5 times as long as wide. Gills on pereonites 3 and 4 elongate, length about 4 times width. - Mouthparts. Upper lip (Fig. 19A) symmetrically bilobed, smooth apically. Mandibles (Fig. 20A,B) without molar; left mandible (Fig. 20B) with incisor and lacinia mobilis 5toothed, followed by a row of plates decreasing in size; right mandible (Fig. 20A) with incisor 6-toothed, lacinia mobilis transformed into a plate minutely serrate distally, followed by row of similar plates decreasing in size; palp 3-articulate, second article with seven setae, distal article with setal formula $1-x-1$, being $x=1$ in the right mandible and 2 in the left one. Lower lip (Fig. 19B) with inner lobes well demarcated; outer lobes with some fine and short setulae apically. Maxilla 1 (Fig. 19D) outer lobe with six robust serrate setae; distal article of the palp with five setae distally and five setae laterally. Maxilla 2 (Fig. 19E) inner lobe rectangular with five setae; outer lobe rectangular about 1.2 times as long as inner lobe, with six setae. Maxilliped (Fig. 19C) inner plate with three robust setae and a slender seta; outer plate with eight simple setae; palp four-articulate, dactylus smooth. - Antennae. Antenna 1 (Fig. 21A) about $2 / 5$ body length; flagellum five-articulate. Antenna 2 (Fig. 21B) about $1 / 3$ length of the antenna 1 , scarcely setose; swimming setae absent; flagellum 2-articulate. - Gnathopods. Gnathopod 1 (Fig. 21C) basis as long as ischium, merus and carpus combined; ischium rectangular; merus rounded; carpus trapezoidal; propodus oval, length about 1.5 times width; palm with acute proximal projection with pair of proximal grasping spines, followed by another pair of proximal grasping spines, and two rows of smaller spines along palm; dactylus slightly curved and smooth. Gnathopod 2 (Fig. 21D) inserted on anterior part of pereonite 2; basis about 1.5 times as long as pereonite 2; ischium and merus rectangular; carpus short and triangular; propodus as long as the basis, length about 2 times width; palm with rows of small grasping spines and a well-developed triangular projection distally; dactylus robust, strongly curved, smooth. - Pereopods. Pereopod 3 and 4 absent (Fig. 18A). Pereopod 5 four-articulate (Figs 18A, 22A). Pereopods 6 (Fig. 22B) and 7 (Fig. 22C) six-articulate; carpus with a grasping spine; propodus with two pairs of proximal grasping spines, followed by a setae, another grasping spine and two setae distally; dactylus of pereopod 7 with a plumose seta. $\bullet$ Penes (Fig. 22D,E) triangular, as long as wide. • Abdomen (Fig. $22 \mathrm{D}, \mathrm{E})$ with two pairs of 2-articulate appendages and a dorsal lobe with two plumose setae; a row of setae present between the penes and the appendages.

Paratype female. • Body length $3.6 \mathrm{~mm}$. Oostegites (Fig. 18B) not setose. Projections on pereonite 3 rounded. Gnathopod 2 (Fig. 21E) with three proximal grasping spines, without triangular projection distally. Abdomen (Fig. 22F) without row of setae between the penes and appendages.
Remarks. The new species strongly resembles Caprellina bispinosa Müller, 1990. Nevertheless both species can be easily distinguished by the segmentation of pereopod 5 , being 2-articulate in C. bispinosa, and four-articulate in Mayericaprella arimotoi.

Distribution. Presently known from Elizabeth and Middleton Reefs, Tasman Sea.

\section{Metaproto Mayer, 1903}

\section{Metaproto novaehollandiae (Haswell, 1880)}

Fig. 23

Proto novae-hollandiae Haswell, 1880: 275-276, pl. 2: fig. 3; Mayer, 1882: 26; Stebbing, 1888: 1230-1232; Mayer 1890: 14-15.

Metaproto novaehollandiae Mayer, 1903: 26-27, pl. 1: figs. 11-12, pl. 6: figs. 24-28, pl. 9: figs 3, 50; Stebbing, 1910: 651-652; McCain \& Steinberg, 1970: 56; Laubitz, 1991: 103-104, fig. 1.

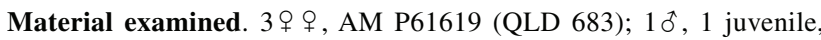

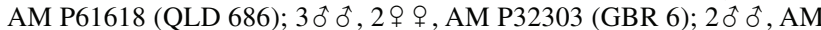
P32309 (GBR 14); 1 ๙ , 2 우, AM P32330 (GBR 56); 2 우 ․, AM P32332 (GBR 63); 1 ठे, AM P32277 (GBR 68); >20 specimens, AM P61695 (QLD 1486); >20 specimens, AM P61696 (QLD 1523); 10, AM P61697 (QLD 1535); 30ิ 0 , 5 우, 1 juvenile, AM P61698 (QLD 1538); 1 , AM P61699 (QLD 1563); 10, AM P61700 (QLD 1571); 60ㅎ, 7 우, AM P61701 (QLD 1572); >20 specimens, AM P61702 (QLD 1574); $>20$ specimens, AM P61703 (QLD 1575).

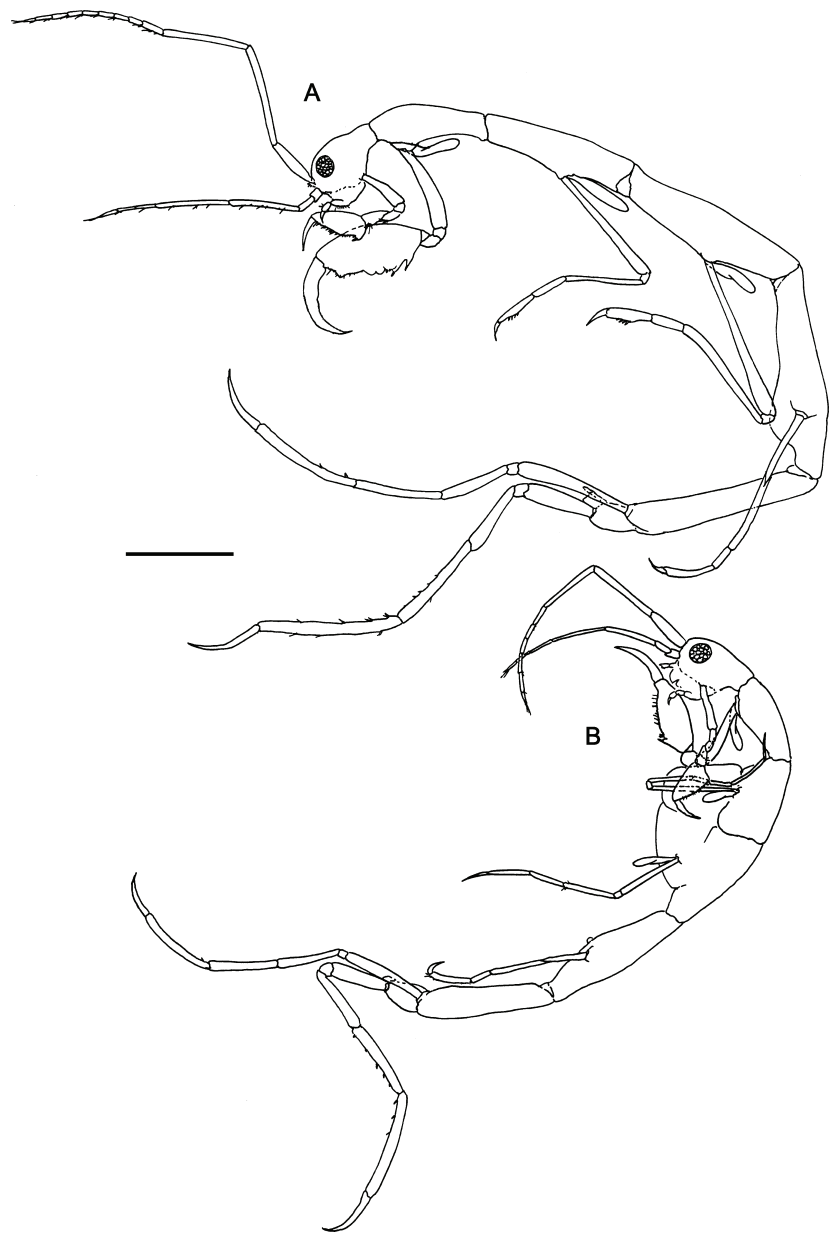

Fig. 23. Metaproto novaehollandiae (Haswell, 1880). Lateral view. $(A)$ male; $(B)$ female. (AM P61702). Scale: $1 \mathrm{~mm}$. 
Remarks. Metaproto can be easily distinguished from all other genera of the Phtisicinae by the presence of only one pair of abdominal appendages. The specimens examined here are in good agreement with those described by Haswell (1880) and redescribed by Mayer (1903) and Laubitz (1991), and with AM specimens collected from Philippines and Papua New Guinea reported by Guerra-García (2002a, 2003). This species was recorded from Queensland by Jones (1984) as Phtisica marina.

Distribution. Port Jackson, New South Wales, Australia (Haswell, 1880), Banda Sea, Indonesia, South Africa (McCain \& Steinberg, 1970), New Caledonia and Philippines (Laubitz, 1991; Guerra-García, 2002a), and Papua New Guinea (Guerra-García, 2003).

\section{Perotripus Dougherty \& Steinberg, 1953}

\section{Perotripus keablei n.sp.}

Figs 24-27

Type material. HOLOTYPE ô, AM P61747, off Mangrove Beach, Lizard Island, Queensland, $14^{\circ} 40^{\prime} \mathrm{S} 145^{\circ} 28^{\prime} \mathrm{E}$, sand, $1.5 \mathrm{~m}$, GBR 6, C. Short \& A.R. Jones, 30 Sep 1978. PARATYPES (all Lizard Island, Queensland): 1 ㅇ, AM P61748, between Bird Islet \& Trawler Beach, $14^{\circ} 40^{\prime} \mathrm{S} 145^{\circ} 28^{\prime} \mathrm{E}$, sand, 15 m, GBR 14, J.K. Lowry \& P.C. Terrill, 5 Oct 1978; 1 ㅇ, AM

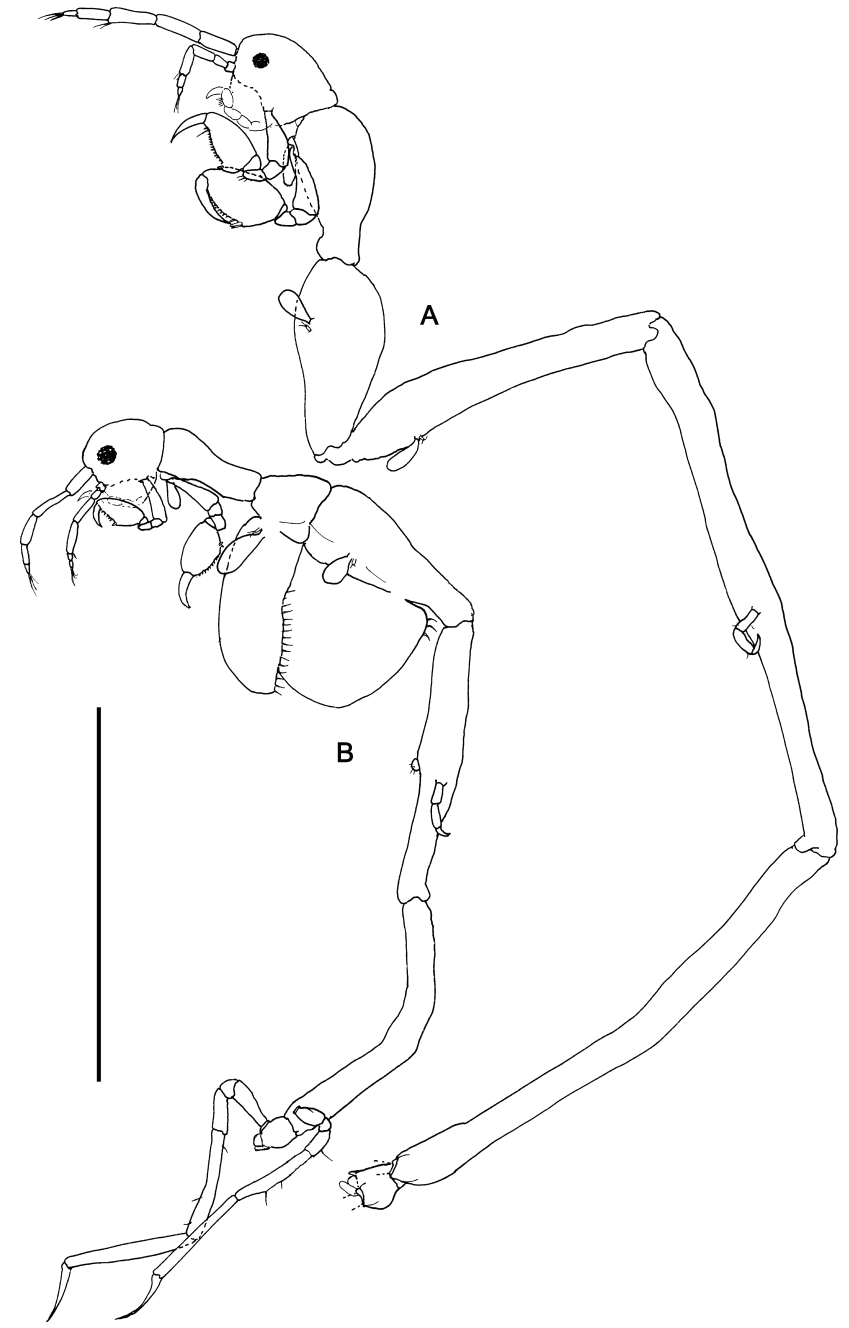

Fig. 24. Perotripus keablei n.sp. Lateral view. $(A)$ holotype male (AM P61747); (B) paratype female (AM P61748). Scale: $1 \mathrm{~mm}$.
P32295, Lagoon, $14^{\circ} 41^{\prime} \mathrm{S} 145^{\circ} 28^{\prime} \mathrm{E}, 1.5 \mathrm{~m}$, GBR 5, C. Short \& P.C. Terrill, 30 Sep 1978; 3 tิ $\widehat{0}, 4$ 9 , AM P32304, type locality; 1 , AM P32293, between Mangrove Beach \& South Island, $14^{\circ} 40^{\prime} \mathrm{S} 145^{\circ} 28^{\prime} \mathrm{E}$, sand, 9 m, GBR 7, J.K. Lowry \& P.C. Terrill, 30 Sep 1978; 1 \%, AM P32297, off S end Casuarina Beach, $14^{\circ} 40^{\prime}$ S $145^{\circ} 28^{\prime} \mathrm{E}$, beach sand, low

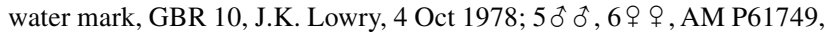
type locality; 1 premature + , AM P32298, between Bird Islet \& South Island, $14^{\circ} 40^{\prime} \mathrm{S} 145^{\circ} 28^{\prime} \mathrm{E}$, coral rubble, $21 \mathrm{~m}$, GBR 15, A.R. Jones, 7 Oct 1978; 1 9, AM P32294, Mermaid Cove, $14^{\circ} 41^{\prime} \mathrm{S} 145^{\circ} 28^{\prime} \mathrm{E}$, sand between corals, 6 m, GBR 26, C. Short \& P.C. Terrill, 8 Oct 1978; 1 \%, AM P32296, Between Bird Islet \& South Island, $14^{\circ} 41^{\prime} \mathrm{S} 145^{\circ} 28^{\prime} \mathrm{E}$, sediment at reef base with mixed algae, $25 \mathrm{~m}$, GBR 29, J.K. Lowry, 9 Oct 1978; 1 ऽ, AM P61750, Blue Lagoon, between Bird Islet and South Island, sediment (medium grained sand), 6 m, QLD 1538, J.M. GuerraGarcía \& S.J. Keable, 13 Oct 2001.

Etymology. Named after Stephen Keable, Australian Museum, for his assistance during the sampling at Lizard Island and for his encouragement, advice, help and friendship during my stay at the Australian Museum.

Diagnosis. Body dorsally smooth. Gills on pereonites 2-4. Flagellum of antenna 12 -articulate. Pereopods 3 and 4 uniarticulate. Pereopod 5 with 3 articles. Abdomen without appendages.

\section{Description}

Holotype male. • Body length. $5.2 \mathrm{~mm}$. - Lateral view (Fig. 24A). Body dorsally smooth. Head rounded. Pereonite 1 fused with head, suture almost absent; pereonites 2 and 3 rounded; pereonites 4-6 elongate; pereonites 5 and 6 subequal in length; pereonite 7 the shortest. - Gills (Fig.

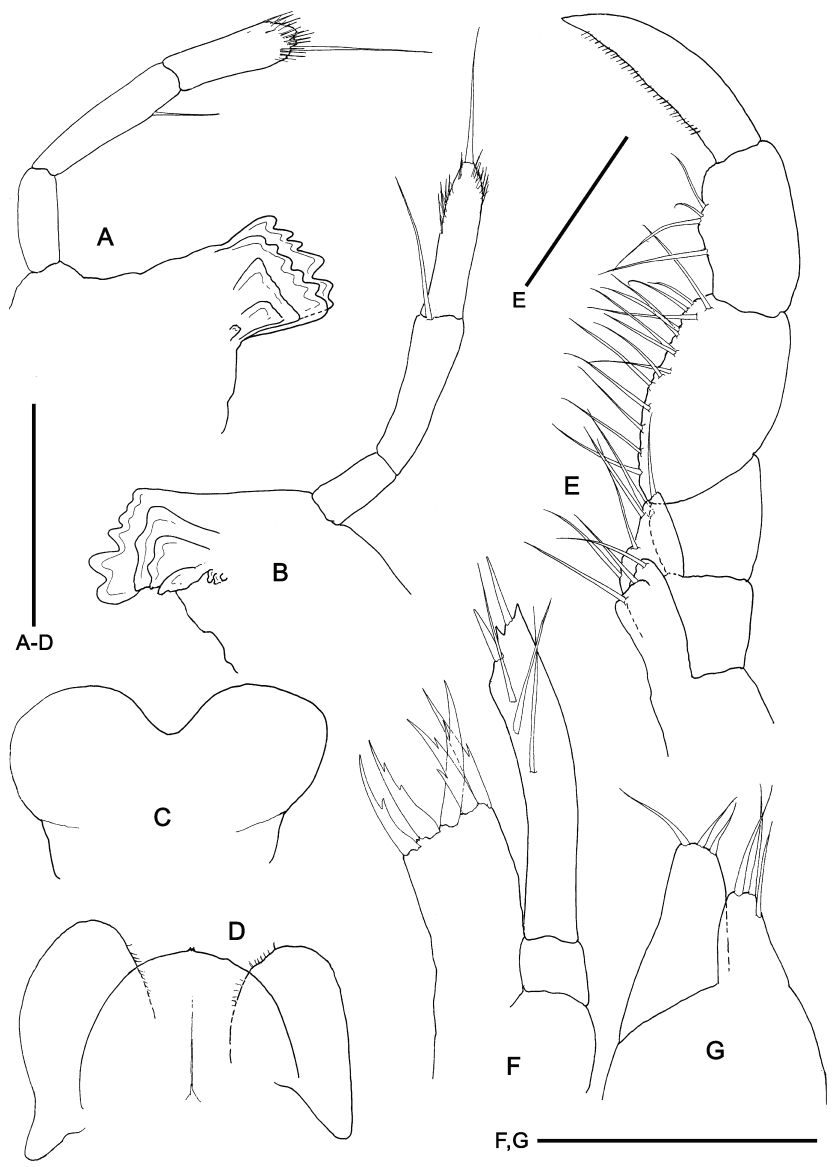

Fig. 25. Perotripus keablei n.sp. Holotype male (AM P61747). $(A)$ left mandible; $(B)$ right mandible; $(C)$ upper lip; $(D)$ lower lip; $(E)$ maxilliped; $(F)$ maxilla $1 ;(G)$ maxilla 2 . Scale: $0.05 \mathrm{~mm}$. 


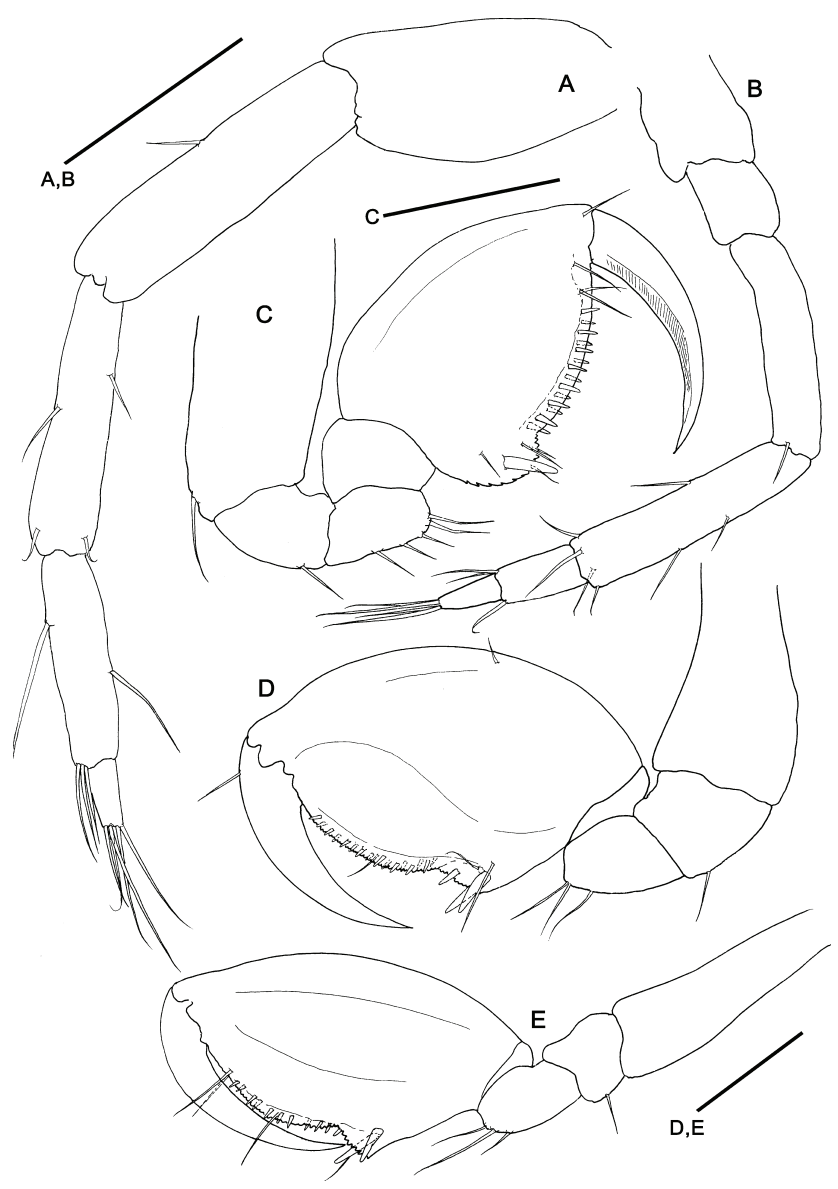

Fig. 26. Perotripus keablei n.sp. (A-D) holotype male (AM P61747). $(A)$ antenna $1 ;(B)$ antenna $2 ;(C)$ gnathopod $1 ;(D)$ gnathopod 2; $(E)$ paratype female (AM P61748) gnathopod 2. Scales $0.1 \mathrm{~mm}$.

24A). Present on pereonites 2-4, oval, length about two times width. - Mouthparts. Upper lip (Fig. 25C) symmetrically bilobed, smooth apically. Mandibles (Fig. 25A,B) with 3-articulate palp; distal article of palp with one simple apical seta and minute setulae distally; second article with a simple setae; mandibular molar absent; left mandible (Fig. 25A) with 6-toothed incisor, lacinia mobilis 6-toothed followed by three plates decreasing in size respectively; incisor of right mandible (Fig. 25B) 6-toothed, lacinia mobilis transformed into a plate, followed by four more plates decreasing in size respectively. Lower lip (Fig. 25D) with inner lobes fused, forming a semicircular plate; outer lobes with some setulae distally. Maxilla 1 (Fig. 25F) outer lobe with five robust setae, serrate laterally; distal article of the palp with two apical setae and row of three setae medially. Maxilla 2 (Fig. 25G) inner lobe with 3 distal setae; outer lobe about 1.3 times as long as inner lobe, with 3 setae. Maxilliped (Fig. 25E) inner plate rectangular, with three setae distally; outer plate triangular, as long as inner plate; palp four-articulate, dactylus with a row of setulae. - Antennae. Antenna 1 (Fig. 26A) about 1/12 body length; flagellum 2-articulate. Antenna 2 (Fig. 26B) about $2 / 3$ length of antenna 1; swimming setae absent; flagellum 2-articulate. - Gnathopods. Gnathopod 1 (Fig. 26C) basis as long as the ischium, merus and carpus combined; propodus oval, length about 1.2 times width, palm serrate proximally with a

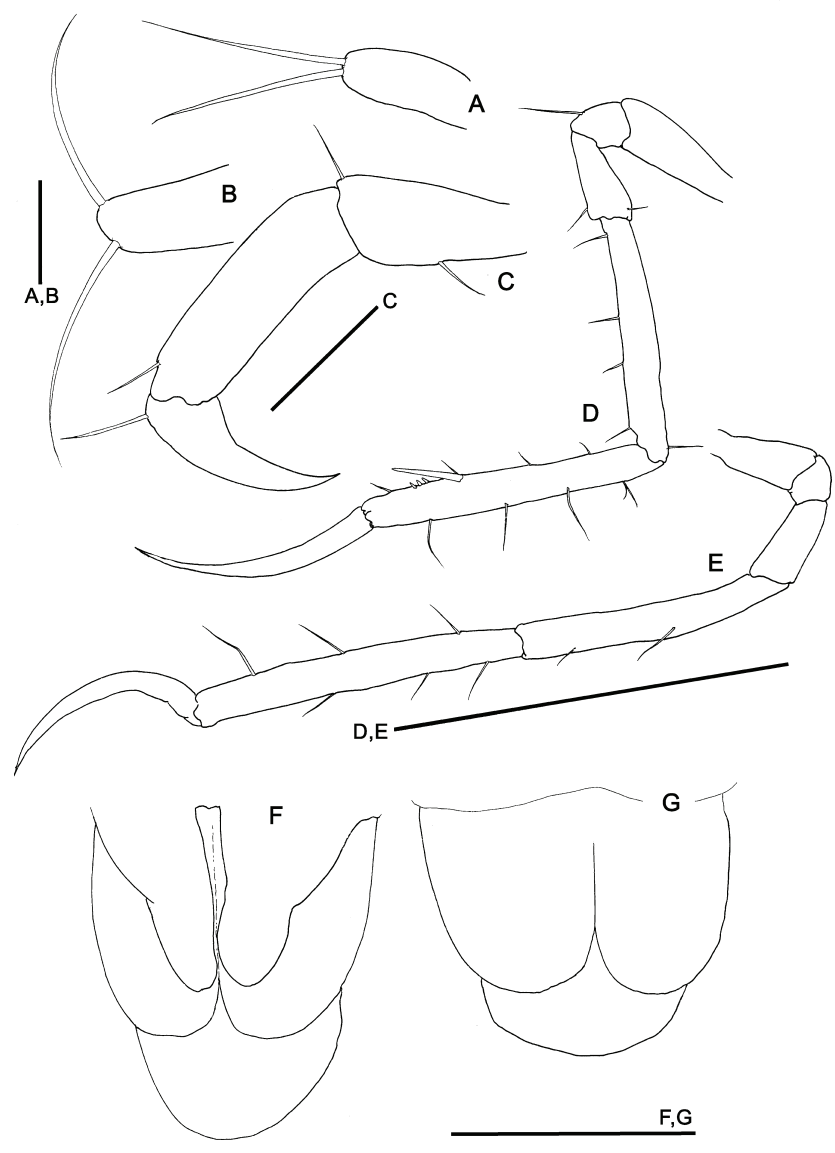

Fig. 27. Perotripus keablei n.sp. $(A-C, F)$ holotype male (AM P61747); $(D, E)$ paratype male (AM P61749). (A) pereopod 4; $(B)$ pereopod $3 ;(C)$ pereopod $5 ;(D)$ pereopod $6 ;(E)$ pereopod $7 ;(F)$ abdomen (ventral view); $(G)$ paratype female (AM P61748) abdomen (ventral view). Scales (mm): A,B: 0.02; C,F,G: 0.05; D,E: 0.5 mm.

grasping spines and two rows of smaller spines along the palm; dactylus elongate and slightly curved, smooth. Gnathopod 2 (Fig. 26D) inserted on anterior half of pereonite 2 (Fig. 24A); basis length one-half of pereonite 2 ; ischium rectangular; merus rounded; carpus short and triangular; propodus oval, about 1.3 times as long as basis; palm with three grasping spines proximally and two rows of smaller spines along palm; dactylus short and slightly curved, with dorsal seta proximally. $\bullet$ Pereopods. Pereopods 3 and 4 (Fig. 27A,B) subequal, small and one-articulate, with two setae distally. Pereopod 5 (Fig. 27C) 3-articulate and sparsely setose. Pereopods 6 and 7 six-articulate (Fig. 27D,E). Propodus of pereopod 6 with large spine followed by three smaller spines, distally robust, propodus of pereopod 7 without spines (missing in holotype, described from a male paratype). - Penes (Fig. 27F) positioned medially, large, length about 2.5 times width. Abdomen (Fig. 27F) without projections except for two lateral lobes and one dorsal lobe.

Paratype female. • Body length $2.7 \mathrm{~mm}$. Pereonites 4-6 (Fig. 24B) shorter than in male; propodus of gnathopod 2 (Fig. 26E) twice as long as wide. Oostegites sparsely setose (Fig. 24B). Palm of pereopod 6 without spines (Fig. 24B).

Remarks. The only other known species of Perotripus is $P$. brevis (La Follette, 1915) from the west coast of North 
America, redescribed in detail by Laubitz (1970). Perotripus keablei n.sp. differs from $P$. brevis mainly on the basis of the following characters: $(a)$ pereonites 2 and 3 are smooth instead of sculptured with lateral projections; $(b)$ pereopod 3 uniarticulate instead of 3-articulate; (c) the penes are large instead of small; (d) the abdomen lacks a pair of small appendages. According to the differences in the number of articles on pereonite 3 and the appendages of the abdomen, a new genus could be erected for the present species. Nevertheless, $P$. keablei agrees well in other respects with P. brevis, as in the striking shape of the body, the structure of antennae, the number of articles on pereopod 5, and the morphology of mouthparts. - Perotripus can be distinguished from the other genera of the Phtisicinae by the 2-articulate flagellum of antenna 1 and the striking shape of the body, especially in males, with long pereonites 5 and 6 .

Distribution. Presently known only from Lizard Island, Queensland, Australia.

\section{Protogeton Mayer, 1903}

\section{Protogeton inflatus Mayer, 1903}

Fig. 28

Protogeton inflatus Mayer, 1903: 28-29, pl. 1: fig. 13, pl. 6: figs. 29-32, pl. 9: figs. 11, 35, 51; Utinomi, 1947: 69.

Material examined. Syntypes, 1 के, 1 \&, ZMA Amph. 107194, Dongala,

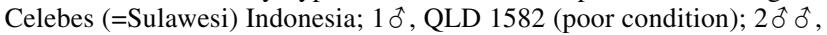
3 9 , QM W12566, Middle Banks, Moreton Bay, Queensland, Australia, P. Saenger \& J. Cook, 1983.

Remarks. Protogeton is characterized by the absence of abdominal appendages. Among phtisicines, this character is also present in Pseudoproto Mayer, 1903. Nevertheless, features of pereopods 3 and 4 in males of Protogeton inflatus are unique within the Caprellidae: the carpi, propodi and dactyli are curved, and with lateral expansions. Furthermore, the mandibular palp is reduced to one article in Protogeton while is normally 3 -articulate in Pseudoproto. The specimens studied from Queensland are in agreement with the type material described by Mayer (1903) from Indonesia. Taking into consideration that material of Protogeton inflatus from Queensland was in poor condition, type material is illustrated to facilitate identification.

Distribution. Dongala, Celebes, Indonesia (Mayer, 1903), Tanabe Bay, Japan (McCain \& Steinberg, 1970), Philippines and Papua New-Guinea (Guerra-García, 2002a, 2003); a new record for Australia. 


\section{Pseudoprellicana n.gen.}

Diagnosis. Antenna 2 flagellum 2-articulate. Gills present on pereonites 3 and 4 . Pereopods 3 and 4 absent. Pereopod 53 -articulate. Pereopods 6 and 7 six-articulate. Mandibular palp 3-articulate. Molar absent. Abdomen with two pairs of appendages.

Etymology. The name is derived from "Pseudo" and "Prellicana" because the new genus strongly resembles Prellicana. Gender: feminine.

Type species. Pseudoprellicana johnsoni n.sp., by present designation and monotypy.

Remarks. The new genus is close to Prellicana Mayer, 1903. The main difference between these two genera is the presence of one pair of uniarticulate abdominal appendages in Prellicana and two pairs in Pseudoprellicana. In connection with the mouthparts, the inner plates of the maxilliped are partially fused in Prellicana, with three denticulate nodular setae, while in Pseudoprellicana the inner plates are not fused and instead of nodular setae the surface is transformed into a structure similar to a molar process. Pereopods 6 and 7 are similar in both genera but pereopod 5 is slightly different. Although in both genera the pereopod 5 is 3-articulate, in Prellicana the basal article is almost divided into two articles while it is not in Pseudoprellicana. The new genus is readily distinguished from Jigurru by the presence of two instead of three pairs of gills.

\section{Pseudoprellicana johnsoni n.sp.}

Figs 29-32

Type material. HoLOTYPE $\widehat{\delta}$, AM P61737, between Bird Islet \& South Island, Lizard Island, Queensland, Australia, $14^{\circ} 40^{\prime} \mathrm{S} 145^{\circ}$, sediment at reef base with mixed algae, 25 m, GBR 27, J.K. Lowry, 9 Oct 1978. PARATYPES (all Lizard Island, Queensland): 19, AM P61738, between Bird Islet \& South Island, $14^{\circ} 41^{\prime} \mathrm{S} 145^{\circ} 28^{\prime} \mathrm{E}$, sediment at reef base with mixed algae, 25 m, GBR 29, J.K. Lowry, 9 Oct 1978; 1 \% , AM P61739, between Bird Islet \& South Island, $14^{\circ} 40^{\prime} \mathrm{S} 145^{\circ} 28^{\prime} \mathrm{E}$ sediment at reef base with mixed algae 25 m, GBR 28, P.C. Terrill, 9 Oct 1978.

Etymology. The species is dedicated to Rick Johnson, Australian Museum, for patiently registering all the material in the collections, and for his help and friendship during my stay at the Australian Museum.

Diagnosis. As for genus.

\section{Description}

Holotype male. $\bullet$ Body length $2.8 \mathrm{~mm}$. Lateral view (Fig. 29A). Body smooth without projections; head rounded; suture between head and pereonite 1 absent; pereonites 25 increasing in size respectively; pereonite 7 the shortest. - Gills (Fig. 29A) present on pereonites 3-4, oval, length about 2 times width.Mouthparts. Upper lip (Fig. 30B) symmetrically bilobed, lobes poorly demarcated, smooth apically. Mandibles (Fig. 30D,E) without molar; left mandible (Fig. 30D) with 5-toothed incisor and lacinia mobilis, followed by a row of plates decreasing in size; right mandible (Fig. 30E) with 5-toothed incisor, lacinia mobilis coarsely toothed, followed by row of plates decreasing in size; palp 3-articulate, second article with one seta, distal article with two setae. Lower lip (Fig. 30C) with inner lobes

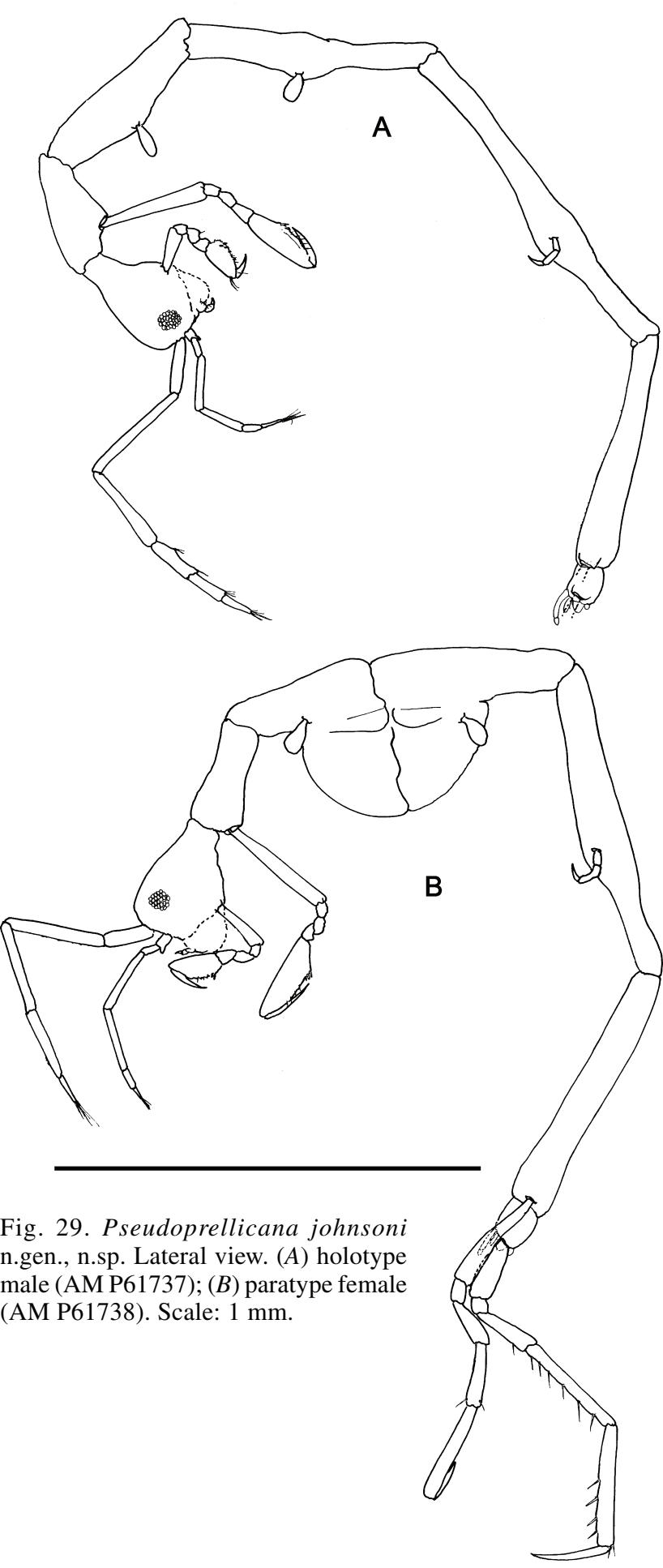

well demarcated; inner and outer lobes smooth, without setae. Maxilla 1 (Fig. 30F) outer lobe with six robust setae; distal article of palp with three robust setae and three serrate teeth distally and row of three setae laterally. Maxilla 2 (Fig. $30 \mathrm{G}$ ) inner lobe oval with four setae; outer lobe rectangular, about 1.3 times longer than inner lobe, with five setae. Maxilliped (Fig. 30A) inner plate distally forming molarlike process with two setae; outer plate with three simple setae and serrate margin; palp four-articulate, dactylus smooth. - Antennae. Antenna 1 (Fig. 31A) about $1 / 3$ of the body length; flagellum 3-articulate. Antenna 2 (Fig. 31B) almost half-length of antenna 1; swimming setae absent; 


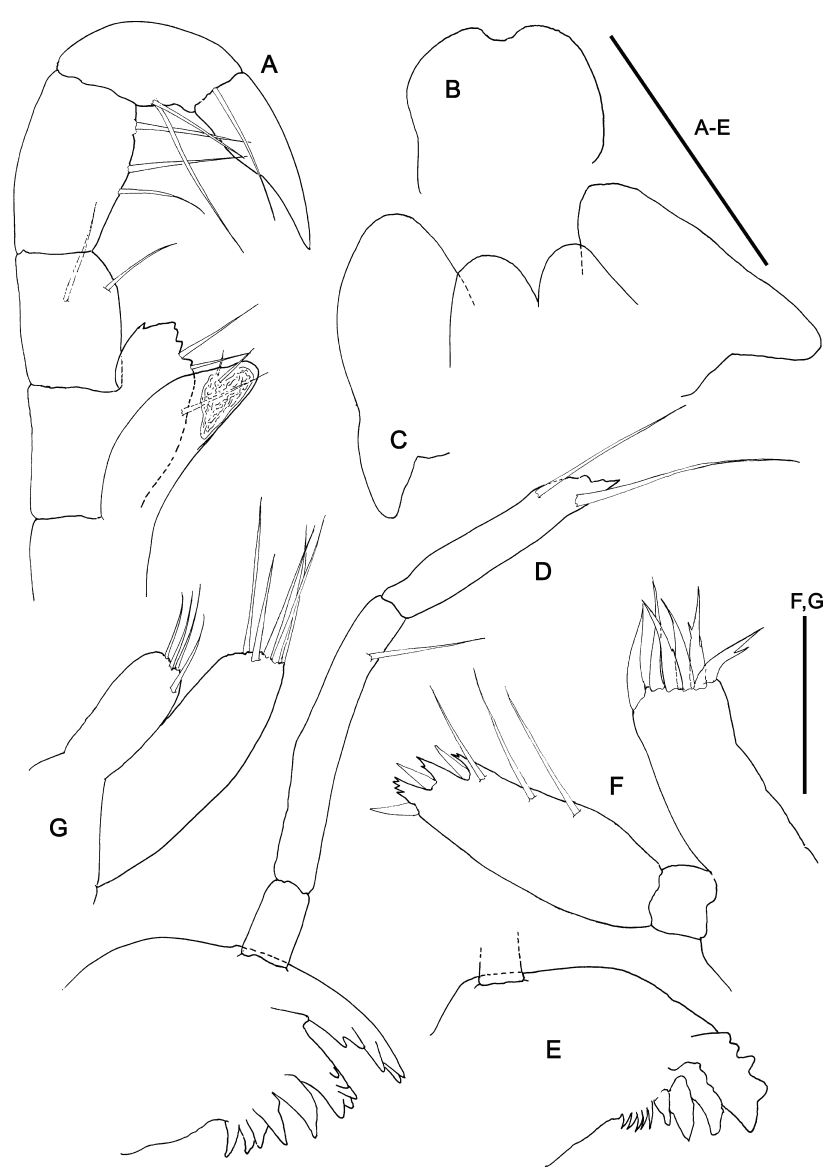

Fig. 30. Pseudoprellicana johnsoni n.gen., n.sp. Holotype male (AM P61737). (A) maxilliped; $(B)$ upper lip; $(C)$ lower lip; $(D)$ left mandible; $(E)$ right mandible; $(F)$ maxilla $1 ;(G)$ maxilla 2. Scales $0.05 \mathrm{~mm}$.

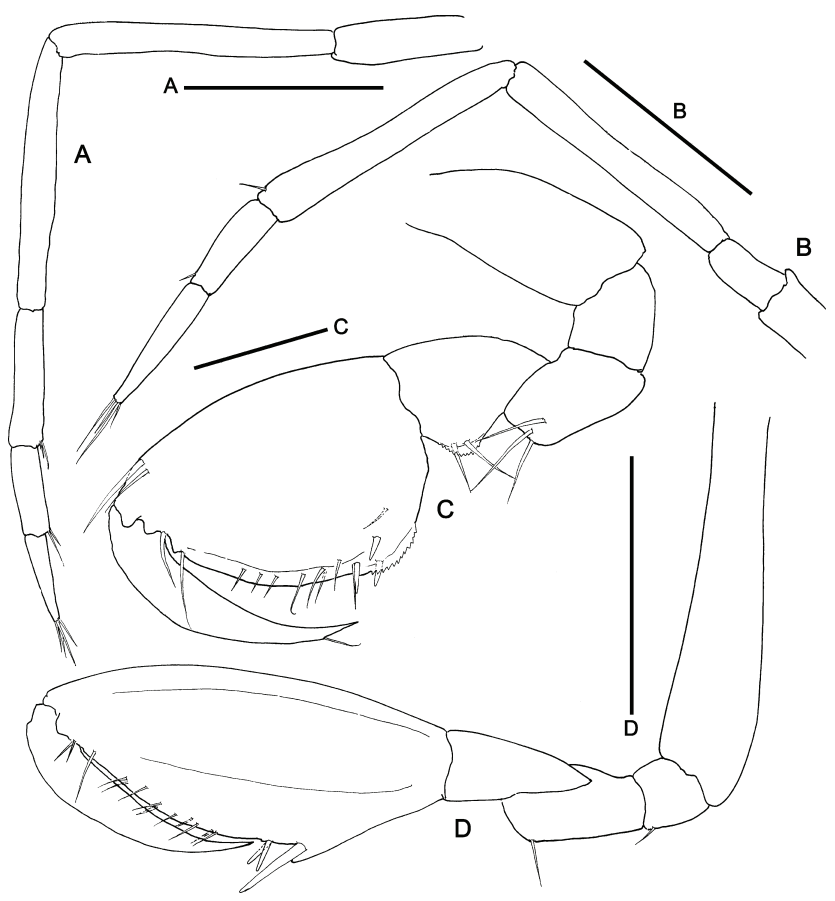

Fig. 31. Pseudoprellicana johnsoni n.gen., n.sp. Holotype male (AM P61737). $(A)$ antenna $1 ;(B)$ antenna $2 ;(C)$ gnathopod 1 ; (D) gnathopod 2. Scales $0.1 \mathrm{~mm}$.

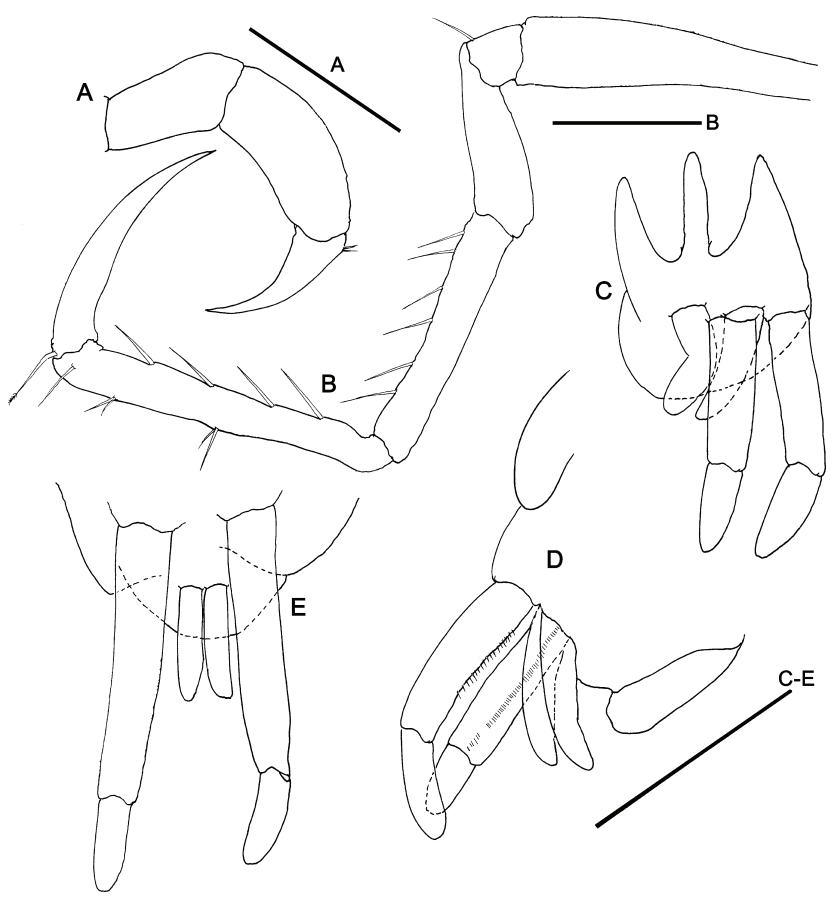

Fig. 32. Pseudoprellicana johnsoni n.gen., n.sp. $(A, C, D)$ holotype male (AM P61737); $(B, E)$ paratype female (AM P61738). (A) pereopod $5 ;(B)$ pereopod $7 ;(C, E)$ abdomen (ventral view); $(D)$ abdomen (lateral view).

flagellum 2-articulate. - Gnathopods. Gnathopod 1 (Fig. 31C) basis as long as the ischium, merus and carpus combined; ischium and merus rectangular; carpus triangular with serrate margin ventrally; propodus oval, length about 1.5 times width, palm with three proximal grasping spines, grasping margin serrate on anterior half; dactylus slightly curved, with a distal seta. Gnathopod 2 (Fig. 31D) inserted on anterior part of pereonite 2; basis as long as pereonite 2; ischium rectangular; merus and carpus slightly elongate; propodus elongate (length about 2.5 times width), with three proximal grasping spines and row of setae along palm; dactylus short and slightly curved, smooth. - Pereopods. Pereopod 3 and 4 absent (Fig. 29A). Pereopod 53 -articulate (Fig. 32A). Pereopods 6 and 7 missing (described from the female paratype AM P61738) • Penes (Fig. 32C,D) elongate, three times as long as wide with small apical suture. - Abdomen (Fig. 32C,D) with two pair of appendages and small dorsal lobe; first pair of appendages long, 2-articulate; second pair shorter, uniarticulate.

Paratype female. Body length $2.7 \mathrm{~mm}$. Oostegites (Fig. 29B) not setose. Gnathopods and abdomen (Fig. 32E) similar to those of holotype male. Pereopods 6 and 7 (Fig. 32B) subequal, six-articulate, carpus and propodus elongate, with row of setae ventrally; dactylus with plumose seta distally.

Remarks. Despite extensive sampling at Lizard Island, only three specimens of Pseudoprellicana johnsoni n.sp. were found, all on sediments at $25 \mathrm{~m}$ depth. Whether the species is naturally uncommon, or has narrow habitat requirements, remains to be determined.

Distribution. Presently known only from Lizard Island, Queensland. 


\section{Pseudoproto Mayer, 1903}

\section{Pseudoproto fallax Mayer, 1903}

Fig. 33

Pseudoproto fallax Mayer, 1903: 27-28, pl. 6, fig. 22; pl. 9, figs 5, 52; Mayer, 1912: 8-9, fig. 3; Utinomi, 1947: 69.

Material examined. 4 syntype females, 1 syntype juvenile, ZMUCCRU-6398, Koh Kauv and Koh Chuen, Thailand; 1 premature $q$, 1 , AM P61734 (QLD 1475).

Remarks. Only two specimens of $P$. fallax were found during the present study, collected from filamentous algal turf attached to dead, thick, branching hard coral. Although no males were found, the present specimens are identified as P. fallax after consulting the type material of the species and on the basis of the combination of the following characters: three pairs of gills, flagellum of antenna 2 with two articles, pereopod 3 and 4 six-articulate, pereopod 5 five-articulate with the distal article elongate and provided with setae distally.

Distribution. Koh Kauv and Koh Chuen, Thailand (Mayer, 1903), Shark Bay, Western Australia (McCain \& Steinberg, 1970); a new record for Queensland, Australia.
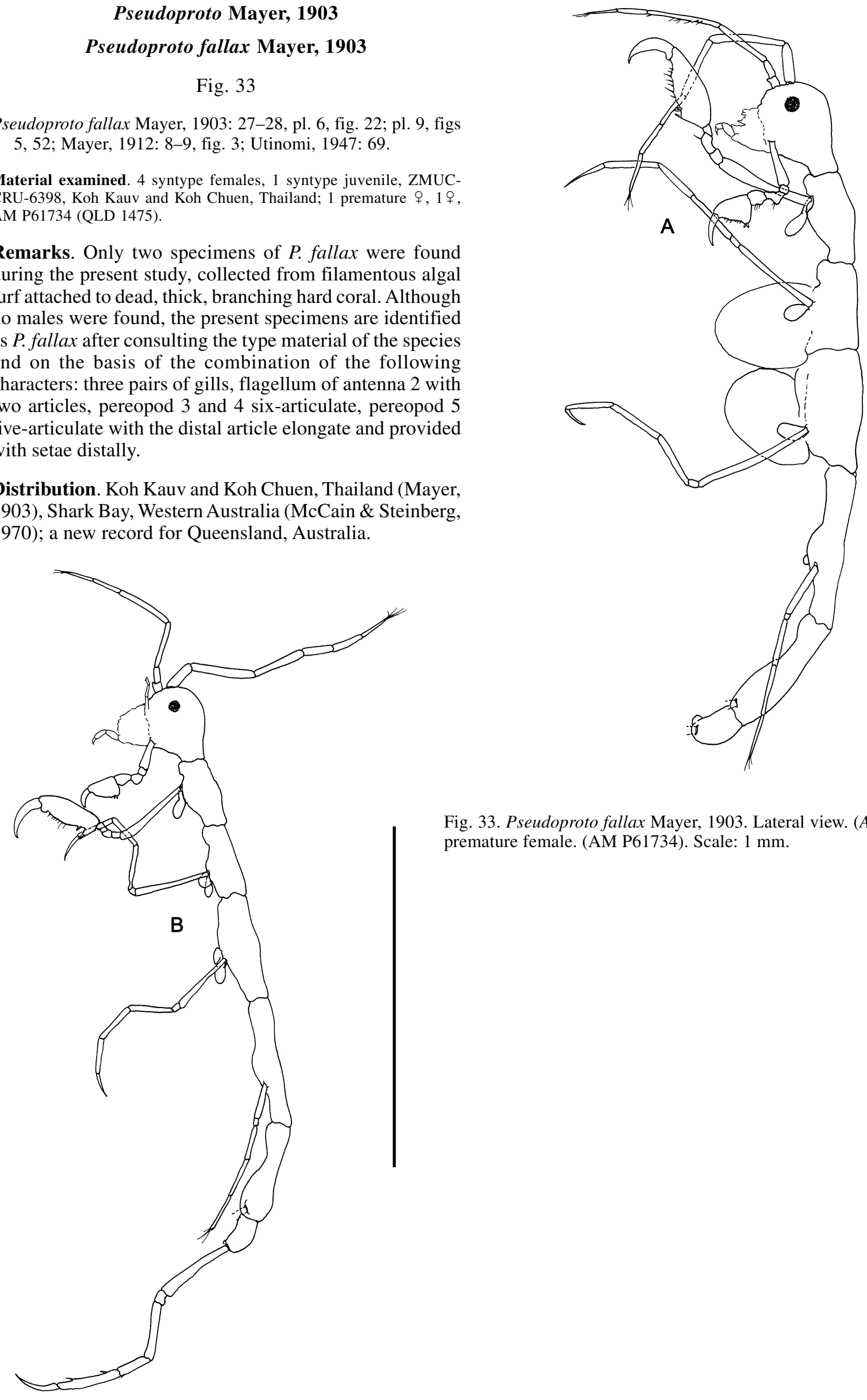

Fig. 33. Pseudoproto fallax Mayer, 1903. Lateral view. (A) female; (B) premature female. (AM P61734). Scale: $1 \mathrm{~mm}$. 


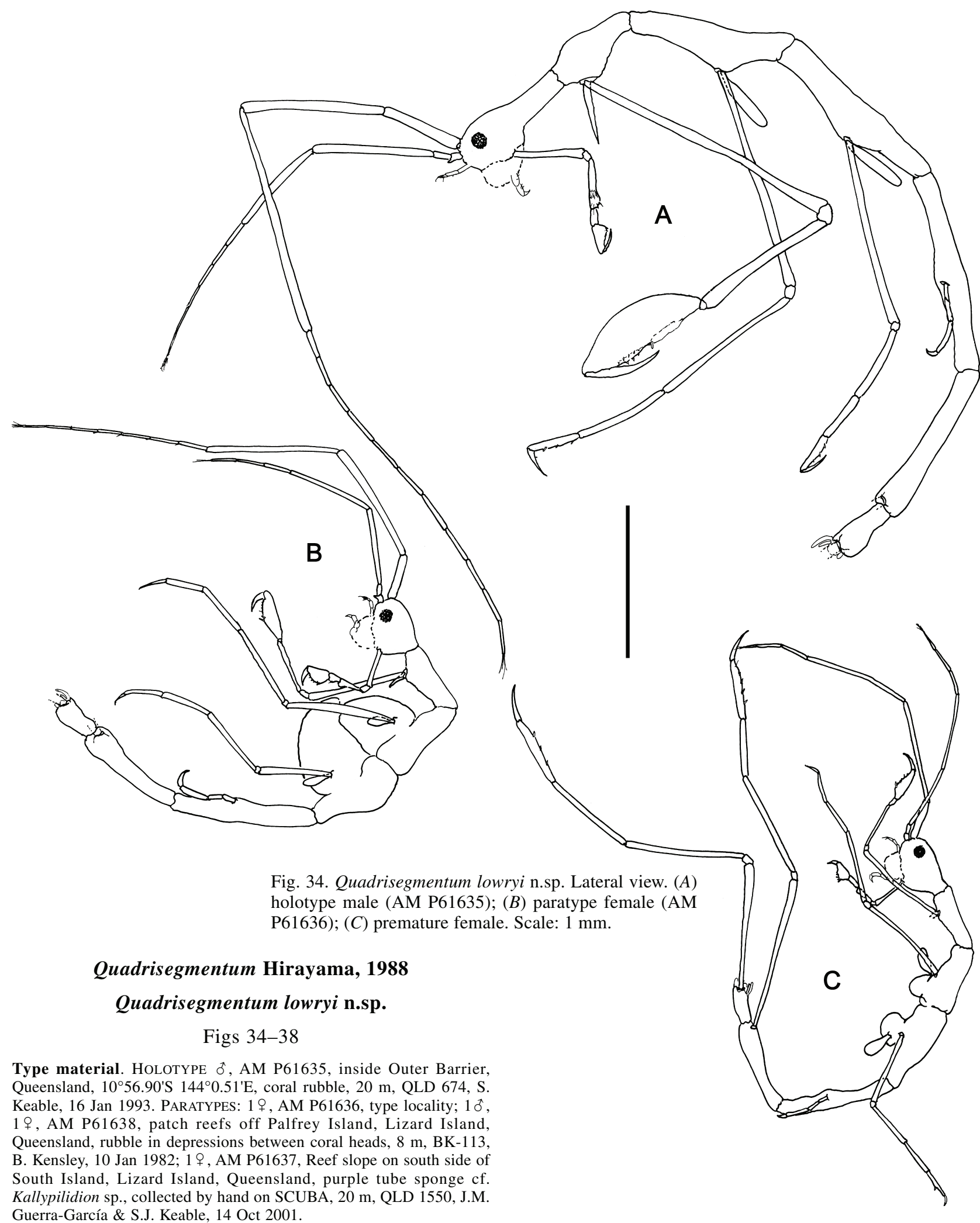

Guerra-García \& S.J. Keable, 14 Oct 2001.

Etymology. Named after Jim Lowry, Australian Museum for his help and hospitality during my stay at the Australian Museum, and for his considerable contributions to the knowledge of the amphipod crustaceans along the world.

Diagnosis. Body dorsally smooth. Gills on pereonites $2-4$. Pereopods 3 and 4 longer than pereonites 3 and 4 combined. Propodus of male gnathopod 2 without projection. Abdominal appendages uniarticulate.

\section{Description}

Holotype male. $\bullet$ Body length. $6.2 \mathrm{~mm}$. Lateral view (Fig. 34A). Body smooth dorsally. Head rounded. Pereonite 1 fused with head, suture absent; pereonites 2-5 increasing slightly in length respectively; pereonite 7 the shortest. - Gills (Fig. 34A). Present on pereonites 2-4. Elongate, length about 4 times width. First pair, on pereonite 2, 


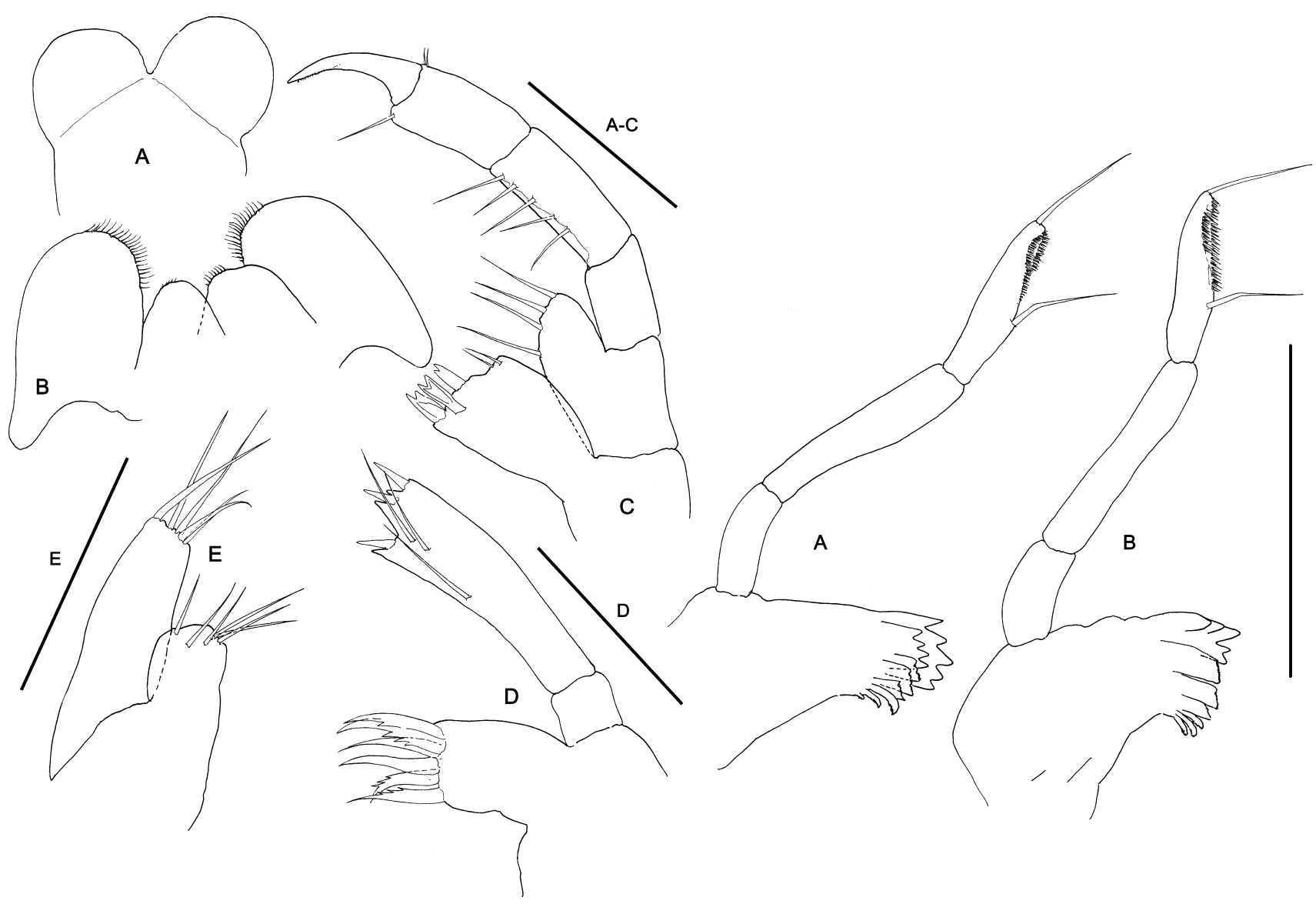

Fig. 35. Quadrisegmentum lowryi n.sp. Holotype male (AM P61635). (A) upper lip; (B) lower lip; $(C)$ maxilliped; $(D)$ maxilla $1 ;(E)$ maxilla 2. Scales $0.05 \mathrm{~mm}$.

triangular. • Mouthparts. Upper lip (Fig. 35A) symmetrically bilobed, lobes well demarcated and smooth apically. Mandibles (Fig. 36A,B) with 3-articulate palp; distal article of palp with two setae and two rows of minute setulae; mandibular molar absent; left mandible (Fig. 36A) with incisor 5-toothed, lacinia mobilis 4-toothed followed by three plates and three plumose setae; incisor of right mandible (Fig. 36B) 5-toothed, lacinia mobilis forming minutely serrate plate, followed by two more plates and three plumose setae; molar flake absent. Lower lip (Fig. 35B) with inner lobes well-demarcated; inner and outer lobes provided with setulae on apical end. Maxilla 1 (Fig. 35D) outer lobe with six robust setae serrate; distal article of palp with three robust setae and three teeth distally, and three setae medially. Maxilla 2 (Fig. 35E) inner lobe oval, with six setae distally; outer lobe elongate, rectangular, 1.5 times as long as inner lobe, with five apical setae. Maxilliped (Fig. 35C) inner plate with three robust nodular setae (like teeth) distally; outer plate smaller than inner plate with four setae; palp four-articulate, articles 1-3 rectangular, article 4 (dactylus) small and curved. Antennae. Antenna 1 (Fig.
Fig. 36. Quadrisegmentum lowryi n.sp. Holotype male (AM P61635). (A) left mandible; $(B)$ right mandible mandible. Scale: $0.1 \mathrm{~mm}$.

37A) almost as long as the body; flagellum 11-articulate; peduncular articles elongate. Antenna 2 (Fig. 37B) flagellum six-articulate; proximal article of peduncle with small projection distally; articles 3 and 4 of peduncle elongate; swimming setae absent. • Gnathopods. Gnathopod 1 (Fig. 37C) basis as long as ischium, merus and carpus combined; ischium short and rectangular; merus with setulae and four setae on distal end; propodus triangular, palm with four proximal grasping spines; dactylus smooth and scarcely curved. Gnathopod 2 (Fig. 37D) inserted on anterior half of pereonite 2; basis about three times as long as pereonite 2 ; ischium rectangular; merus elongate, about the half basis length; carpus short and triangular; propodus as long as merus; palm with proximal cavity filled with a membranous sack, followed by a grasping spine and two distal rows of smaller spines along the palm; dactylus smooth, strongly curved. • Pereopods. Pereopods 3 (Fig. 38A) and 4 (Fig. 38B) six-articulate. Propodus with three grasping spines along palm on pereopod 3 and four spines on pereopod 4; merus and carpus longer on pereopod 3 than on pereopod 4. Pereopod 5 (Fig. 38C) four-articulate. Pereopods 6 and 


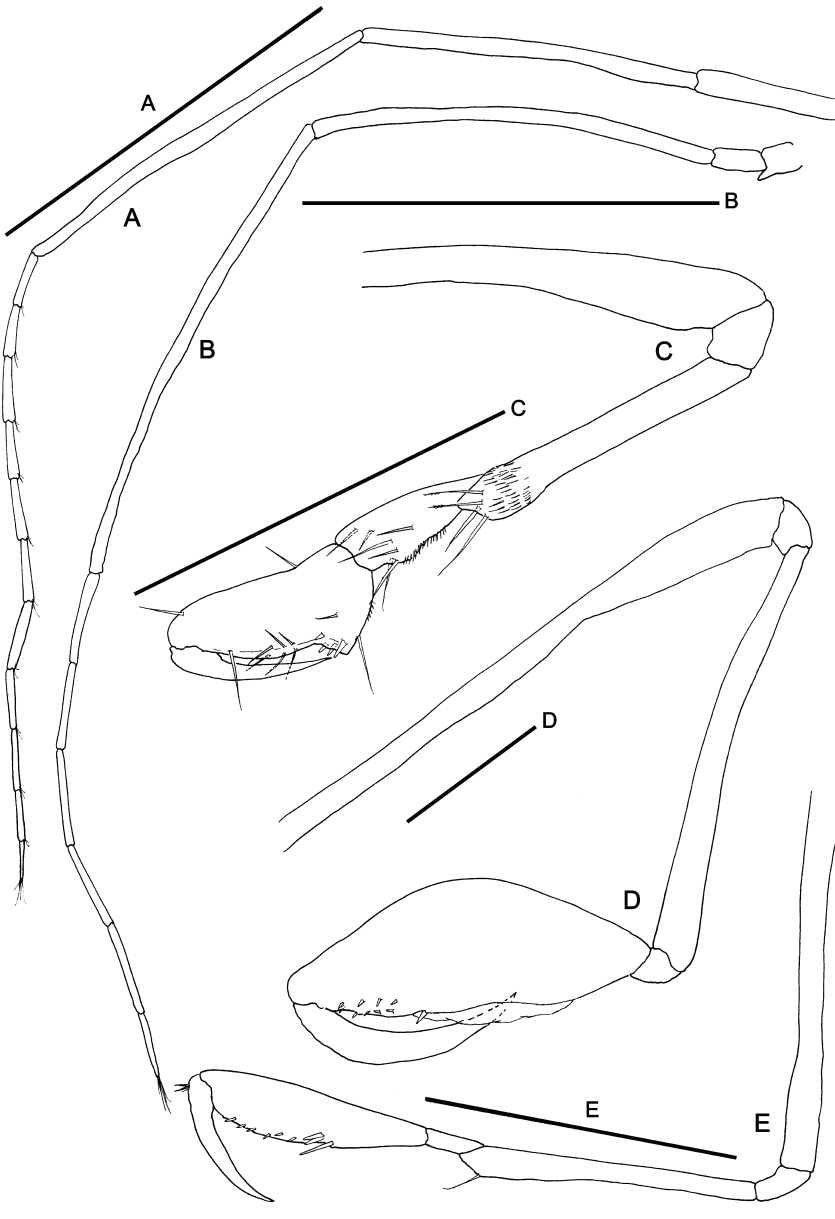

Fig. 37. Quadrisegmentum lowryi n.sp. (A-D) holotype male (AM P61635). (A) antenna 1; $(B)$ antenna 2; $(C)$ gnathopod 1; $(D)$ gnathopod 2; $(E)$ paratype female (AM P61636) gnathopod 2. Scales: A: $0.5 \mathrm{~mm}$; B: $0.1 \mathrm{~mm}$; C: $0.3 \mathrm{~mm}$; D,E: $0.2 \mathrm{~mm}$.

7 missing in holotype (described for female below). Penes. Reduced to a pair of tiny appendages situated medially (Fig. 38F). Abdomen. (Fig. 38F) with two pair of uniarticulate appendages (although the first pair is provided with a basal peduncle), and a dorsal lobe.

Paratype female. - Body length $3.8 \mathrm{~mm}$. Flagellum of antenna 1 seven-articulate; flagellum of antenna 23 articulate (Fig. 34B). Carpus of gnathopod 2 (Fig. 37E) about three times as long as wide, more elongate than in male, with 3 grasping spines and without membranous sack proximally. Pereopods 6 and 7 (Fig. 38D,E, 34C) sixarticulate, propodus with four grasping spines and one setae on pereopod 6 and three grasping spines and one setae on pereopod 7. Oostegites not setose (Fig. 34B).

Remarks. Quadrisegmentum lowryi $\mathrm{n} . \mathrm{sp}$ is close to its only congener $Q$. triangulum. The main differences between the two species are: $(a)$ the antennae, gnathopods and pereopods 6 and 7 are clearly longer in $Q$. lowryi; $(b)$ the propodus of the gnathopod 2 male is provided with a developed distal

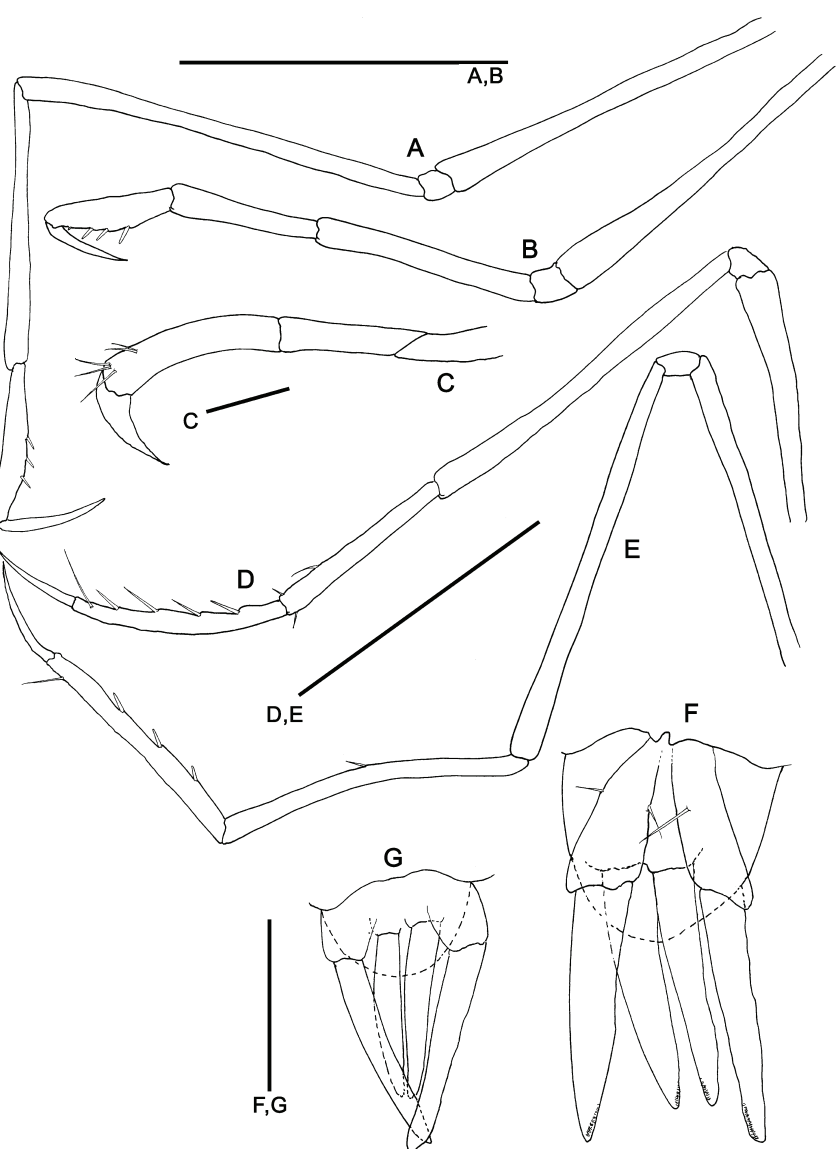

Fig. 38. Quadrisegmentum lowryi n.sp. $(A-C, F)$ male holotype (AM P61635); $(D, E, G)$ paratype female. $(A)$ pereopod 3; $(B)$ pereopod $4 ;(C)$ pereopod $5 ;(D)$ female pereopod $6 ;(E)$ female pereopod 7; $(F) \mathrm{G}$, abdomen (ventral view). Scales: A,B,D,E: 0.5 $\mathrm{mm}$; C: $0.1 \mathrm{~mm}$; F,G: $0.05 \mathrm{~mm}$.

triangular projection in $Q$. triangulum while this projection is absent in $Q$. lowryi; $(c)$ the abdominal appendages are 2articulate in $Q$. triangulum and one-articulate in $Q$. lowryi.

Besides these differences, the membranous sack present on the male propodus palm of $Q$. lowryi seems not to be present in Q. triangulum (Hirayama, 1988). Nevertheless this character should be used carefully because it varies allometrically. For example, Krapp-Schickel (1993) figured the variation of the gnathopod 2 in adult males of Phtisica marina. Some males of Phtisica marina (superadult) bear the membranous sac and one grasping spine, while another lacks the membranous structure, having 3 grasping spines proximally.

Distribution. Inside Outer Barrier (10 $\left.56.90^{\prime} \mathrm{S} 144^{\circ} 1.22^{\prime} \mathrm{E}\right)$ and Lizard Island, Queensland, Australia. 
Fig. 39. Quadrisegmentum triangulum

Fig. 39. Quadrisegmentum triangulum
Hirayama, 1988. Lateral view. (A) male; $(B)$ female. (AM P61725). Scale: $1 \mathrm{~mm}$.

\section{Quadrisegmentum triangulum Hirayama, 1988}

\section{Fig. 39}

Quadrisegmentum triangulum Hirayama, 1988: 1089-1093, figs. $1-3$.

Material examined. $>20$ specimens, AM P61630 (QLD 704); 1 ऊ, AM P61625 (QLD 705); $20 \hat{\jmath}, 2$ 웅, AM P61629 (QLD 722); 1 ㅇ, AM P61624 (QLD 734); 10 ,

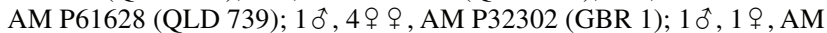
P32314 (GBR 25); 1 premature female, AM P32318 (GBR 29); 2 ๙ $\widehat{0}$,

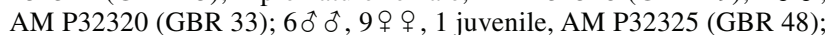
1 ㅇ, AM P32326 (GBR 49); $7 \hat{o} \hat{o}, 1$ ㅇ, 1 juvenile AM P32327 (GBR

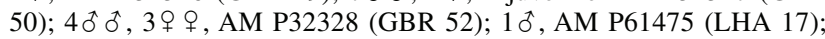

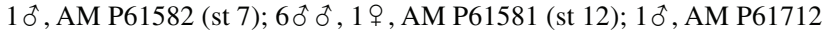

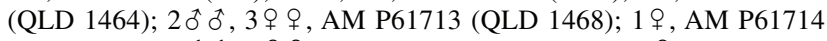
(QLD 1469); 4 oิ 0 , 4 우 오, AM P61715 (QLD 1476); 1 ㅇ, 2 juveniles, AM P61716 (QLD 1483); 1 juvenile, AM P61717 (QLD 1485); 20 ઈ,

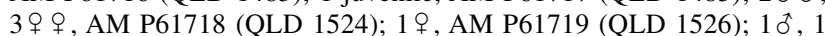
premature female, AM P61720 (QLD 1528); 2 ㅇ ․ AM P61721 (QLD 1536); 1 ठ , AM P61722 (QLD 1541); > 20 specimens, AM P61723 (QLD 1544); 1 ઈ, AM P61724 (QLD 1545); 20 ठ , AM P61725 (QLD 1565); 1ㅇ, AM P61726 (QLD 1568); 1엉 AM P61727 (QLD 1569); 10, 1 juvenile, AM P61728 (QLD 1573); 10, AM P61729 (QLD 1581); 10, AM P61730 (QLD 1588).

Remarks. Quadrisegmentum was recently established by Hirayama (1988) for Q. triangulum. The material examined from Queensland agrees well with the specimens described by Hirayama (1988). This is one of the most abundant caprellid species on the Great Barrier Reef.

Distribution. West Islet, Ashmore Reef, Northwest Australia (12¹4.28'S 122 $\left.{ }^{\circ} 59.14 ' E\right)$ (Hirayama, 1988), Papua New Guinea (Guerra-García, 2003); a new record for Queensland, Australia.

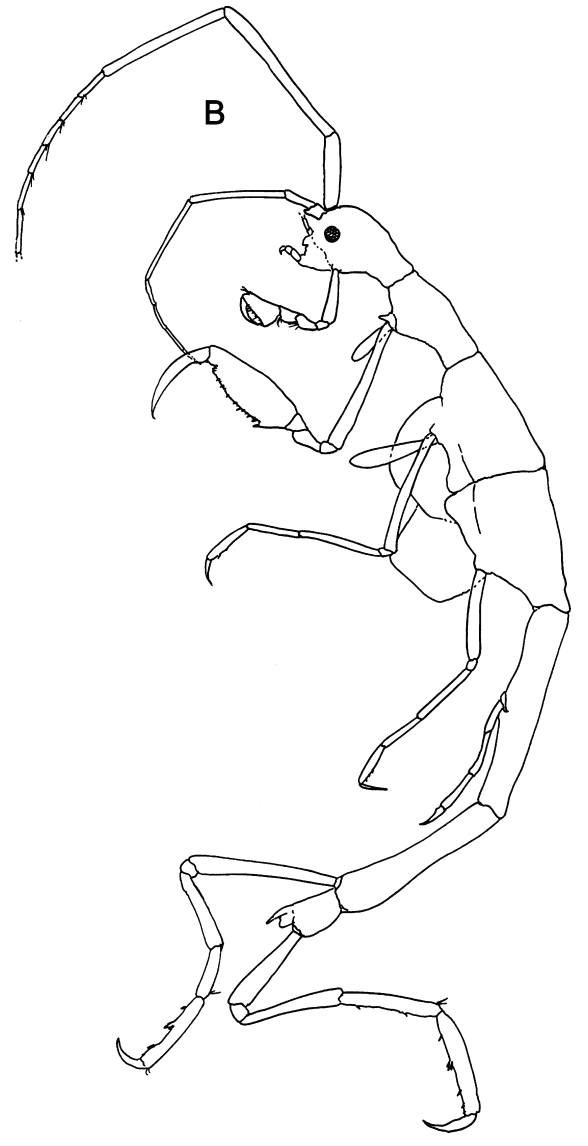

A
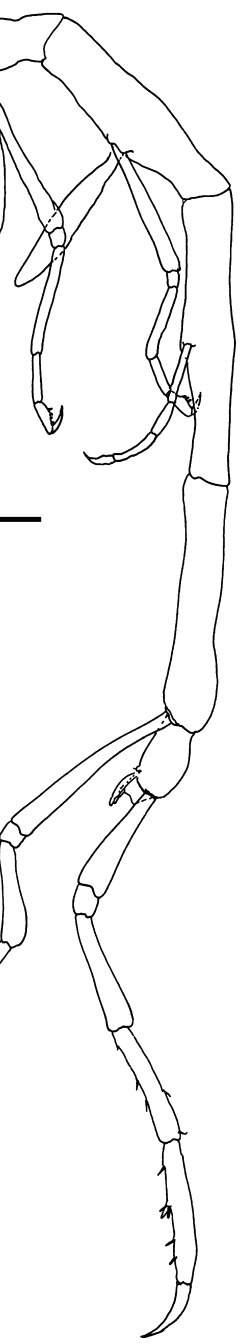


\section{Subfamily Caprellinae Leach, 1814}

\section{Aciconula Mayer, 1903}

\section{Aciconula australiensis Guerra-García, 2004}

Fig. 40

Aciconula australiensis Guerra-García, 2004: 23-29, figs. 19-23.

Material examined. 1 $₫$, AM P61735 (QLD 1475); 1 $\uparrow, 1$ juvenile, AM P61736 (QLD 1567).

Remarks. This species is uncommon on the Great Barrier Reef. Only three specimens were collected from Lizard Island, clinging to small hydroids or algal turf on dead corals. Aciconula australiensis was recently described based on specimens collected from Western Australia (GuerraGarcía, 2004). The specimens from Queensland are indistinguishable from Western Australian specimens, apart from minor differences in body ornamentation that can be attributed to differences in development.

Distribution. Dampier Archipelago, Western Australia, and now from Queensland, Australia.

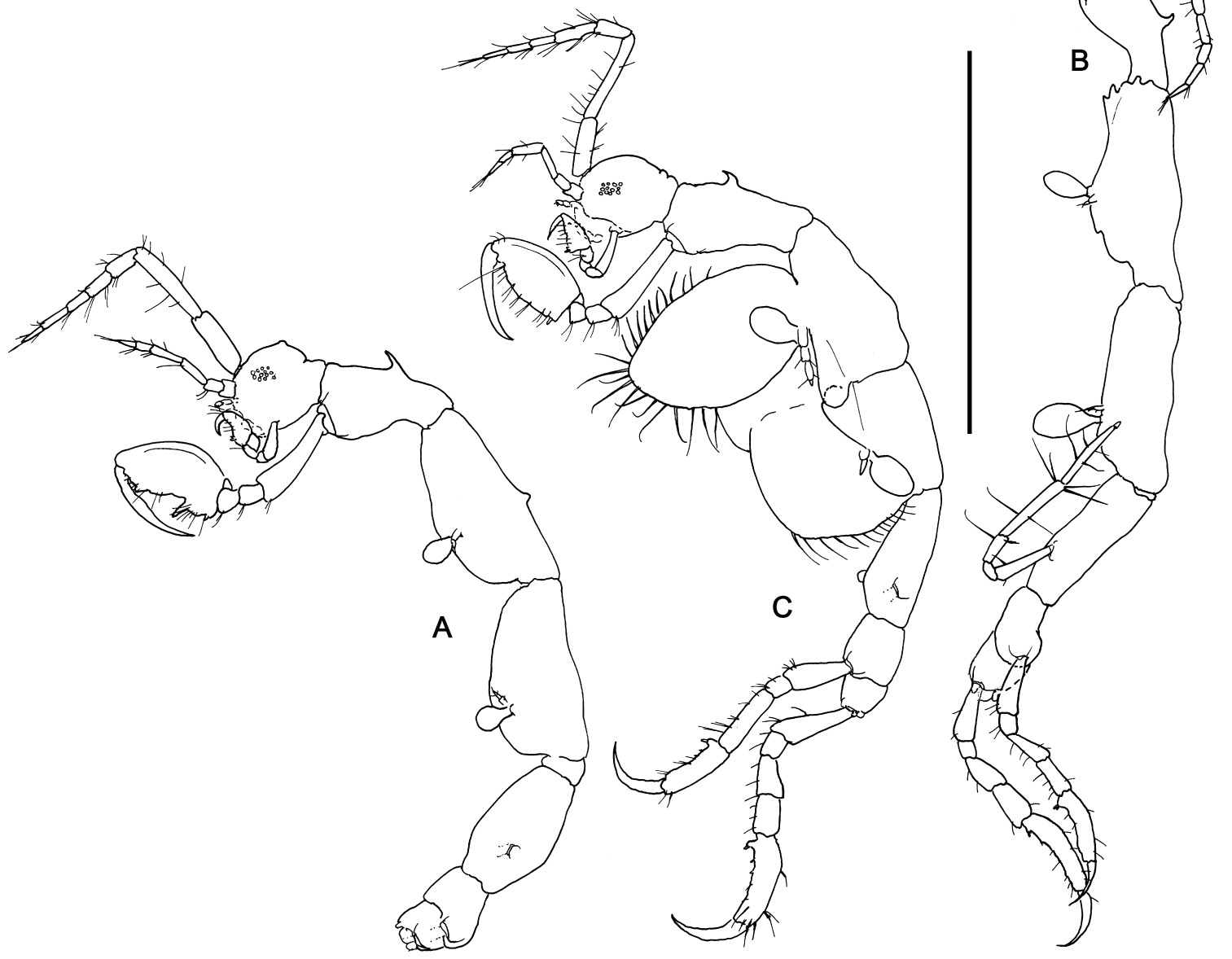

Fig. 40. Aciconula australiensis Guerra-García, 2004. Lateral view. $(A, B)$ males; $(C)$ female. Refigured from Guerra-García (2004). Scale: $1 \mathrm{~mm}$. 


\section{Caprella Lamarck, 1801}

\section{Caprella danilevskii Czerniavskii, 1868}

Fig. 41

Caprella Danilevskii Czerniavskii, 1868: 92, pl. 6: figs. 21-34; Mayer, 1890: 58, pl. 5: fig. 44; pl. 7: figs. 12-13.

Caprella Danilewskii Chevreux \& Fage, 1925: 454, fig. 432.

Caprella danilevskii McCain, 1968: 22, figs. 10-11; McCain \& Steinberg, 1970: 16; Cavedini, 1982: 499; Krapp-Schickel, 1993: 779, fig. 531; Guerra-García \& Takeuchi, 2002: 683684 , fig. 6.

Caprella inermis Haswell, 1879: 319-351.

Material examined. 1 $\widehat{0}, 1$ premature female, AM P61639 (QLD 949);

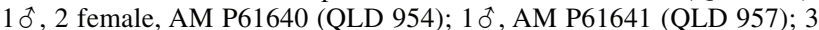
female, AM P61642 (QLD 968); 10, AM P61643 (QLD 969); 2 male, AM P61644 (QLD 972); 1 ㅎ, AM P61645 (QLD 979); $3 \hat{\jmath}$ ô, 2 우 우, AM

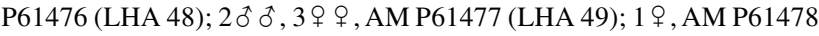
(LHA 51); 1 क, AM P43062, Bustard Head, south of Gladstone, Queensland, $24^{\circ} 02^{\prime} \mathrm{S} 151^{\circ} 46^{\prime} \mathrm{E}$, among Sargassum on rocks, J.S. Hynd, 28 Aug 1946; > 20 specimens, AM P61334, Miami, Queensland, 2804'S $153^{\circ} 27^{\prime} \mathrm{E}$, among weed on rocky headland, J.S. Hynd, Aug 1944.

Remarks. Caprella danilevskii is a cosmopolitan species (Krapp-Schickel, 1993). The distinctive male abdomen, the absence of grasping spines on the pereopods and the short dactylus of male gnathopod 2 distinguish this species from other species of Caprella. The morphology of Queensland specimens agrees with published accounts (Krapp-Schickel, 1993; Guerra-García \& Takeuchi, 2002). The species has been found mainly in southern Queensland, around Shoalwater Bay, Lord Howe Island and the coast near Brisbane. Apparently, this species favours no-coralline habitats.

Distribution. Cosmopolitan (Krapp-Schickel, 1993); a new record for Queensland.

\section{Caprella penantis Leach, 1814}

Fig. 42

Caprella Penantis Leach, 1814: 404.

Caprella acutifrons Mayer, 1882: 48; Mayer, 1890: 50, pl. 2: figs. 36-37, 39-41, pl. 4: figs. 52-53, 55, 57-61, 65-69; Mayer, 1903: 79, pl. 3: figs. 4-28; pl. 7: figs. 62-65.

Caprella penantis McCain, 1968: 33, figs.15-16; McCain \& Steinberg, 1970: 33; Cavedini, 1982: 508; Krapp-Schickel, 1993: 791-793; Guerra-García \& Takeuchi, 2002: 692-693, fig. 12.

Material examined. $4 \hat{\delta} \widehat{\delta}, 1$ premature female, $3 \uparrow \circ, 1$ juvenile, AM P61632 (QLD 658); 1 0 , 1 premature female, 1 \& , 1 juvenile, AM P61631 (QLD 659).

Remarks. Although this species is believed to be cosmopolitan (Krapp-Schickel, 1993), its presence is only occasional along the Great Barrier Reef, having been found in only two samples to the north of the study area. Caprella penantis has been recorded under several species or subspecies names from temperate regions worldwide (McCain, 1968; Laubitz, 1972; Takeuchi \& Hirano, 1995). Further studies are required to determine the status of these nominal taxa.

Distribution. Cosmopolitan; a new record for Queensland.

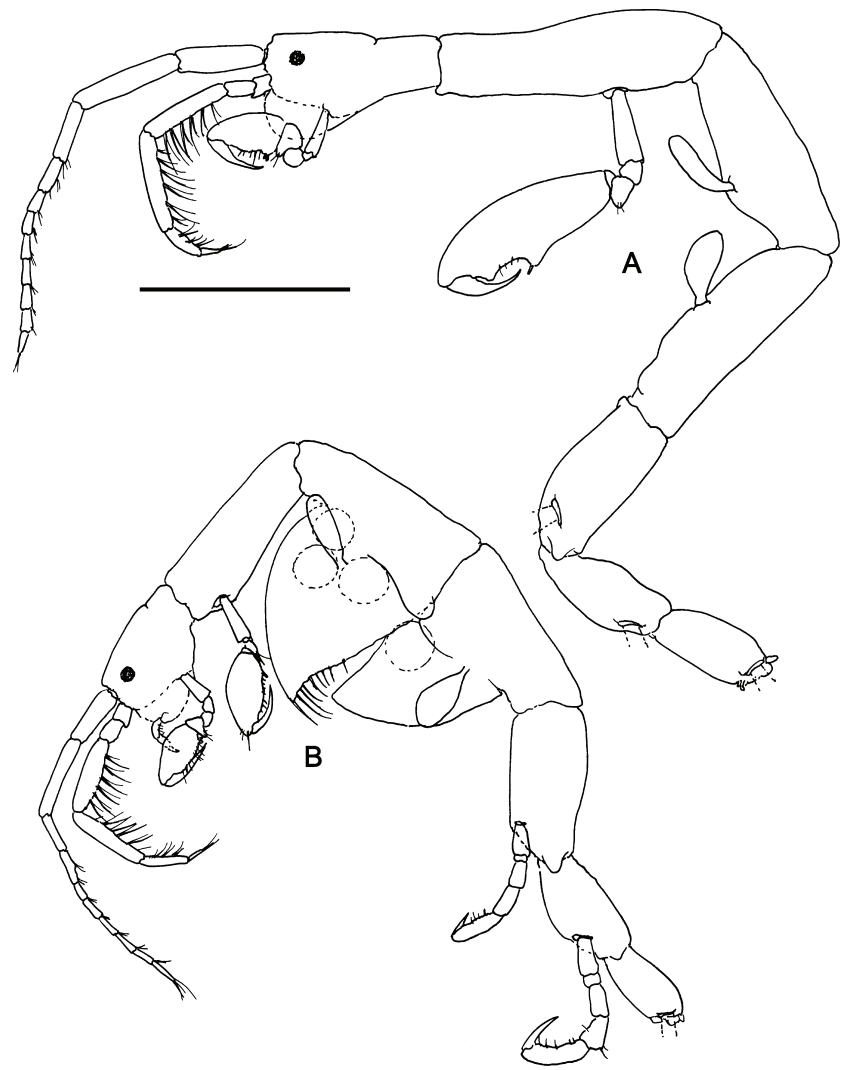

Fig. 41. Caprella danilevskii Czerniavskii, 1868. Lateral view. (A) male (AM P61476); (B) female (AM P61477). Scale: $1 \mathrm{~mm}$.

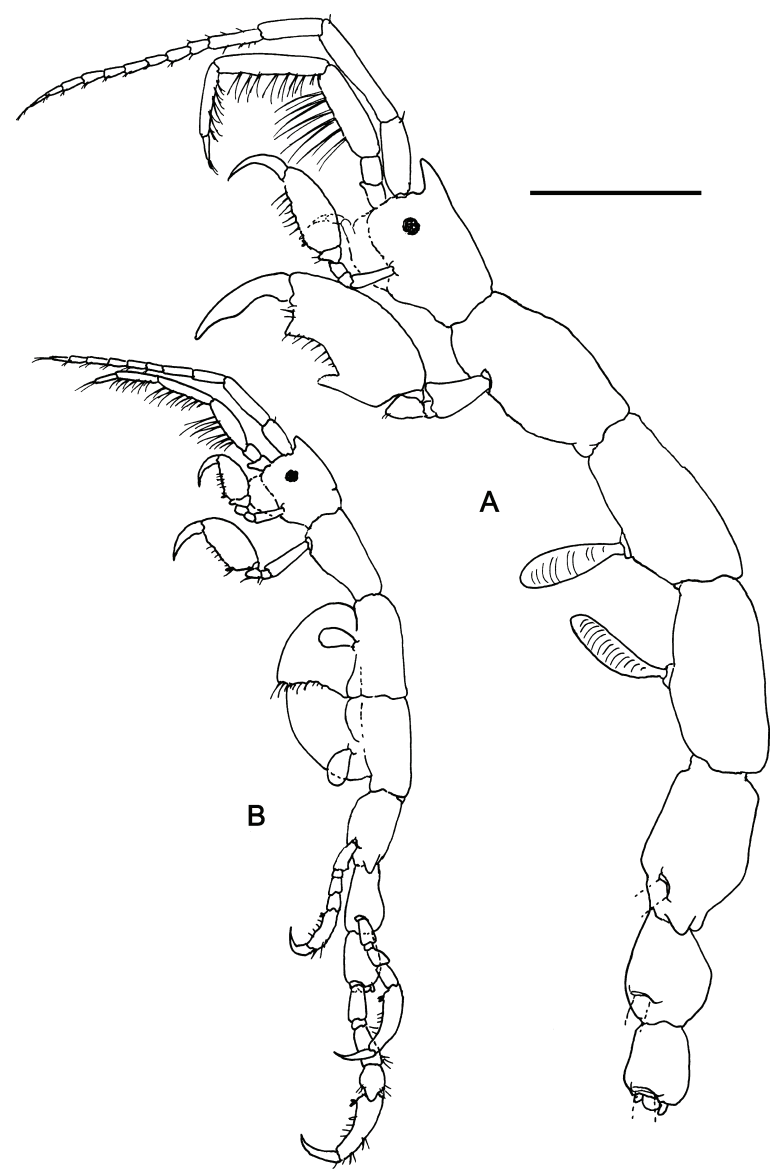

Fig. 42. Caprella penantis Leach, 1814. Lateral view. (A) male; (B) female. (AM P61632). Scale: $1 \mathrm{~mm}$. 


\section{Hemiaegina Mayer, 1890}

\section{Hemiaegina minuta Mayer, 1890}

Fig. 43

Hemiaegina minuta Mayer, 1890: 40, pl. 1: figs. 25-27, pl. 3: figs. 32-35, pl. 5: figs. 52-53, pl. 6: figs. 13, 33-34, pl. 7: fig. 4; McCain, 1968: 61-64, figs. 29-30; McCain \& Steinberg, 1970: 51; Gable \& Lazo-Wasem, 1987: 637; Müller, 1990: 836; Serejo, 1997: 630-632, fig. 1.

Hemiaegina quadripunctata Sundara Raj, 1927: 126-127, pl. 18. Hemiaegina costai Quitete, 1972: 165-168, pls. 1-2.

Material examined. 10, AM P61647 (QLD 980); $50 \hat{\jmath}, 2$ 우, AM P61648 (QLD 979); $1 \hat{0}$, AM P61649 (QLD 972); 1 ․, AM P61650 (QLD 957); 2 đે 1․, AM P61815 (QLD 856); 10 , 3 우, AM P61587 (st 30); 10, 1 \% ,

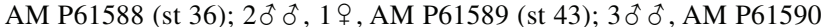

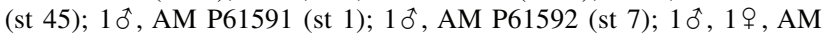
P61593 (st 20); 1 ô., AM P61594 (st 23); 2 ô ô, 3 우 우, AM P61595 (st 21); 1 ઈ, 1 우, AM P61474 (LHA 11); 10 , AM P32307 (GBR 11); 1 , 1 \%, AM P61733 (BK-114); 1 ठิ, QLD 1564.

Remarks. Hemiaegina minuta is widely distributed in tropical and temperate waters worldwide (Müller, 1990). The Queensland specimens agree with the description of McCain (1968) based on material from the West coast of North America.

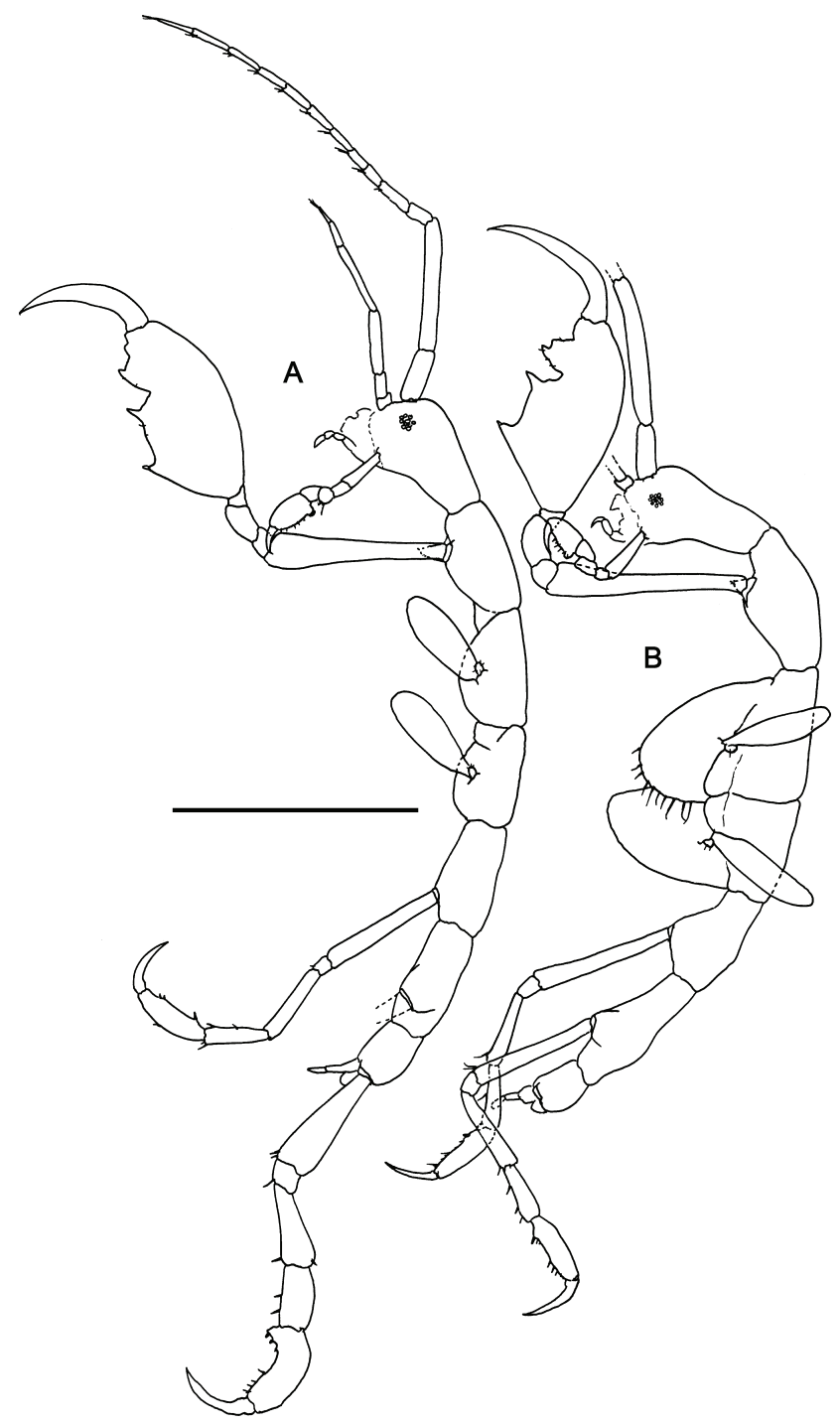

Fig. 43. Hemiaegina minuta Mayer, 1890. Lateral view. (A) male; (B) female. (AM P61648). Scale: $1 \mathrm{~mm}$.
Distribution. Off Amoy, China, 15-46 m deep (Mayer, 1890); off Bermuda; Virginia; Cape Hatteras, North Carolina; Elliot Key, Florida; Loggerhead Key, Tortugas; $29^{\circ} 44^{\prime} \mathrm{N} 88^{\circ} 23.5^{\prime} \mathrm{W}$; Port Aransas, Texas; St. John, Virgin Islands; False Bay, South Africa; Oahu, Hawaii; Bora Bora; Sunohama and Tateyama, Japan; $1^{\circ} 42.5^{\prime} \mathrm{S} 130^{\circ} 47.5^{\prime} \mathrm{E}$; Fremantle, Australia; Krusadai Island, India; South Arabian coast (McCain \& Steinberg, 1970); Papua New Guinea (Guerra-García, 2003); a new record for Queensland, Australia.

\section{Metaprotella Mayer, 1890}

\section{Metaprotella sandalensis Mayer, 1898}

Fig. 44

Metaprotella sandalensis Mayer, 1898: 53-56, figs. 1-6; Mayer, 1903: 40-42, pl. 1: figs. 30-31, 34-36, pl. 6: figs. 56-63, pl. 9: figs.16-17, 44, 60; Müller, 1990: 836-842, figs. 41-64; Müller, 1990: 836-842, figs. 41-64; Laubitz, 1991: 113, fig. 10.

Material examined. Four specimens in poor condition, AM P7986, Ellison Reef, Queensland, $17^{\circ} 43^{\prime} \mathrm{S} 146^{\circ} 25^{\prime} \mathrm{E}$, from coral, $16 \mathrm{~m}$. deep, W.E.G.

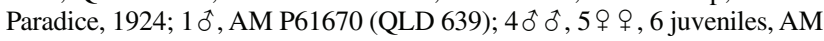
P61666 (QLD 650); >20 specimens, AM P61667 (QLD 646); 1 juvenile,

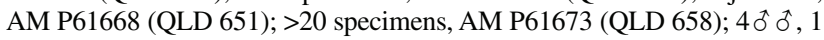
premature female, 1 \% , 1 juvenile, AM P61665 (QLD 659); 1 के, 1 premature female, 4 female, 1 juvenile, AM P61672 (QLD 660); $10^{\star}, 1$ \% , 4 juveniles,

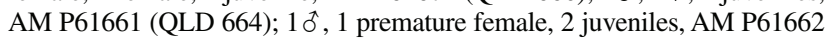
(QLD 667); 1 juvenile, AM P61663 (QLD 668); 1 ㅊ, 1 요 1 juvenile, AM P61669 (QLD 682); 1 to, 4 premature females, 8 우, AM P61671 (QLD 696); >20 specimens, AM P61687 (QLD 721); 1 ㅇ, AM P61680 (QLD 723); 1 premature female, AM P61679 (QLD 724); 1 ऊ, AM P61685 (QLD 733);

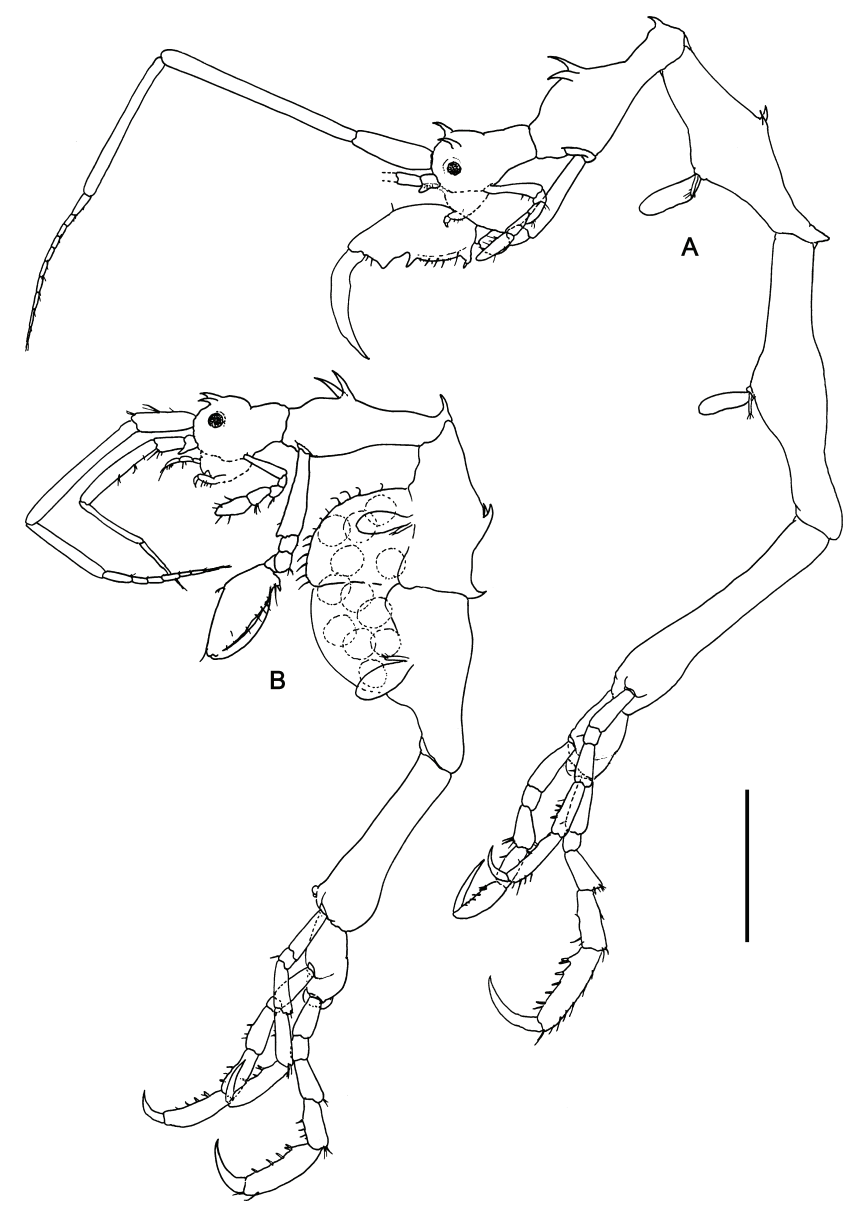

Fig. 44. Metaprotella sandalensis Mayer, 1898. Lateral view. (A) male; $(B)$ female. (AM P61804). Scale: $1 \mathrm{~mm}$. 
10, AM P61681 (QLD 734); 3 우 ․, AM P61684 (QLD 735); 10 , 1 ㅇ, AM P61683 (QLD 760); 1 premature female, AM P61686 (QLD 777); 20 ๙ 1 premature female, AM P61682 (QLD 778); $2 \widehat{\widehat{\delta}}, 1$ juvenile, AM P61658

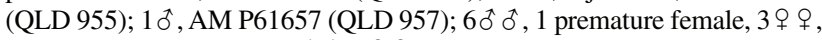
AM P61656 (QLD 979); 30 ๙ 0 , 4 우 + , 2 juveniles, AM P61654 (QLD 983); 1 premature female, AM P61659 (QLD 985); $2 \hat{\delta} \widehat{\delta}, 1$ premature female,

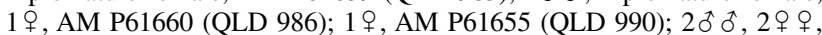
AM P32306 (GBR 11); $5 \hat{0} \hat{\jmath}, 2$ 우 오, AM P32308 (GBR 12); $1 \hat{0}, 1$ premature female, 1 ㅇ, AM P32311 (GBR 19); 9 oิ $\widehat{0}, 3$ premature females,

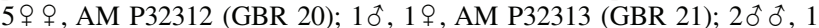
premature female, AM P32316 (GBR 27); 3 premature females, AM P32317 (GBR 28); 10 , AM P61760, (GBR 29); 1 ․, AM P32319 (GBR 30); 10 ,

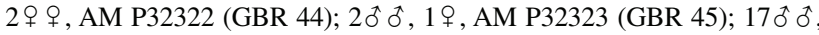
6 우, 2 juveniles, AM P61761 (GBR 50); 10 , 1 premature female, 4 juveniles, AM P32329 (GBR 55); 2 ㅇ ㅇ, AM P32331 (GBR 59); 7 के ठో, 1 premature female, 2 $q$ + , 4 juveniles, AM P61606 (st 1); 2 female, 2 juvenile,

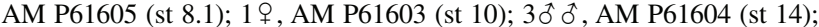

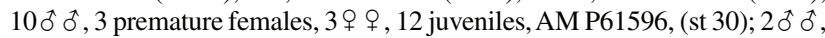

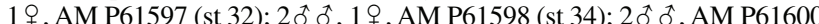

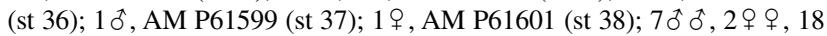
juveniles, AM P61602 (st 43); 1 ㅇ, AM P61779 (QLD 1464); 50 के, AM P61780 (QLD 1465); 20 oิ, 2 ㅇ,+ 2 juveniles, AM P61781 (QLD 1468); $>20$ specimens, AM P61782 (QLD 1470); 1 9, 1 juvenile, AM P61783 (QLD

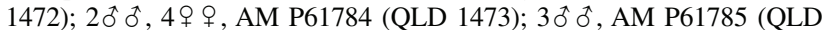
1474); 10, 1 9 , AM P61786 (QLD 1476); 1 premature female, 1 \% , AM P61787 (QLD 1477); >20 specimens, AM P61788 (QLD1478); >20 specimens, AM P61789 (QLD 1484); 1 juvenile, AM P61790 (QLD 1487); 1 ڤै, AM P61791 (QLD 1488); 1 , AM P61792 (QLD 1503); 10, AM P61793

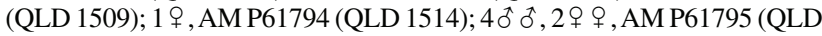

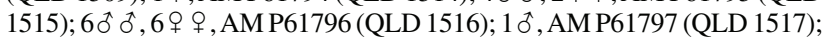
2 우, AM P61798 (QLD 1519); 1 수 1 ㅇ, 1 juvenile, AM P61799 (QLD

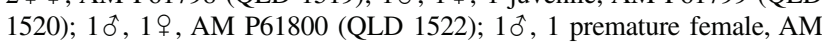
P61801 (QLD 1528); 1 ㅇ, AM P61802 (QLD 1529); 1 premature female, AM P61803 (QLD 1531); $1 \delta^{\star}$, AM P61752 (QLD 1532); 1 \% , AM P61805 (QLD 1543); 1 ㅇ, AM P61806 (QLD 1549); 1 ㅊ, 1 우, AM P61807 (QLD

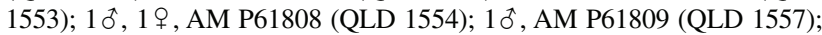
$>20$ specimens, AM P61810 (QLD 1561); 1 के, AM P61811 (QLD 1564); 1․ AM P61812 (QLD 1568); >20 specimens, AM P61804 (QLD 1570);

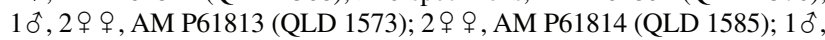
4 ㅇ 9 , QM W22456, North East Herald Cay, Coringa Herald Nature Reserve, Queensland, Australia, $15^{\circ} 56^{\prime} \mathrm{S} 149^{\circ} 11^{\prime} \mathrm{E}$, Halimeda sp, 16-20 m, P. Davie \& M. Preker, 27 Jun 1997.

Remarks. This species, recently redescribed by Müller (1990), is common in shallow waters of the tropical IndoPacific and is clearly the most common species on the Great Barrier Reef. The present specimens are assigned to Metaprotella sandalensis on the basis of the arrangement of the dorsal projections and the absence of a marked suture between the head and pereonite 1 (Larsen, 1997). Nevertheless, the great variety of morphological forms and habitats, even in neighbouring populations (as observed at Lizard Island) could reflect polymorphism or indicate the existence of a species complex. Further studies are necessary to investigate if the variation among specimens is intra- or interspecific.

Distribution. Sandal Bay, Lifu, Loyalty Islands (Mayer, 1898); Labuan Badjo, Borneo; Dongala, Celebes; Pulu Tongkil and $6^{\circ} 07.5^{\prime} \mathrm{N} 120^{\circ} 26^{\prime} \mathrm{E}$, Sulu Sea; Amboina; between Gisser and Ceram-Laut, Ceram Sea; Singapore, Malaysia; Koh Chang and Koh Kahdal, Thailand; Dutch Bay, Ceylon; Sharks Bay and Cockburn Sound, Australia; Viti Levu, Fiji Islands; Aranuka and Tapeteucea, Gilbert Islands; Ralum, $4^{\circ} 20^{\prime} \mathrm{S} 152^{\circ} 10 \mathrm{~W}$; Oahu and Lisiansky Islands, Hawaiian Islands (McCain \& Steinberg, 1970); Bora Bora and Moorea, Society Islands (Müller, 1990); Papua New Guinea (Guerra-García, 2003).

\section{Orthoprotella Mayer, 1903}

\section{Orthoprotella australis (Haswell, 1880)}

Fig. 45

Protella australis Haswell, 1880: 276, pl. 12: fig. 4; Haswell, 1885: 997-998, pl. 49: figs. 2-4; Mayer, 1890: 23.

Orthoprotella australis.-Mayer, 1903: 35-36, pl. 1: figs. 2324, pl. 6: figs. 45, 47-49, pl. 9: figs. 14, 37, 57.

Material examined. $>20$ specimens, AM P32321 (GBR 43); $1 \hat{\delta}$, AM P32324 (GBR 46); 1 ๙ิ, 1 ㅇ, 1 juvenile, AM P61692 (QLD 1559); >20 specimens, AM P61693 (QLD 1560); >20 specimens, AM P61694 (QLD 1562); 2 우, 2 juveniles, AM P61691 (QLD 1582).

Remarks. Orthoprotella australis is easily distinguished from its congeners by the presence of two acute projections on the head. The species seems to be uncommon on the Great Barrier Reef, but large populations were found on hydroids at Lizard Island.

Distribution. Port Jackson, Australia (Haswell, 1880); off Manning River and Port Stephens, Australia; between Gisser and Ceram Laut, Ceram Sea; Pulu Jedan, Arafura Sea; Banda Sea; Sawu Sea (McCain \& Steinberg, 1970); a new record for Queensland, Australia.

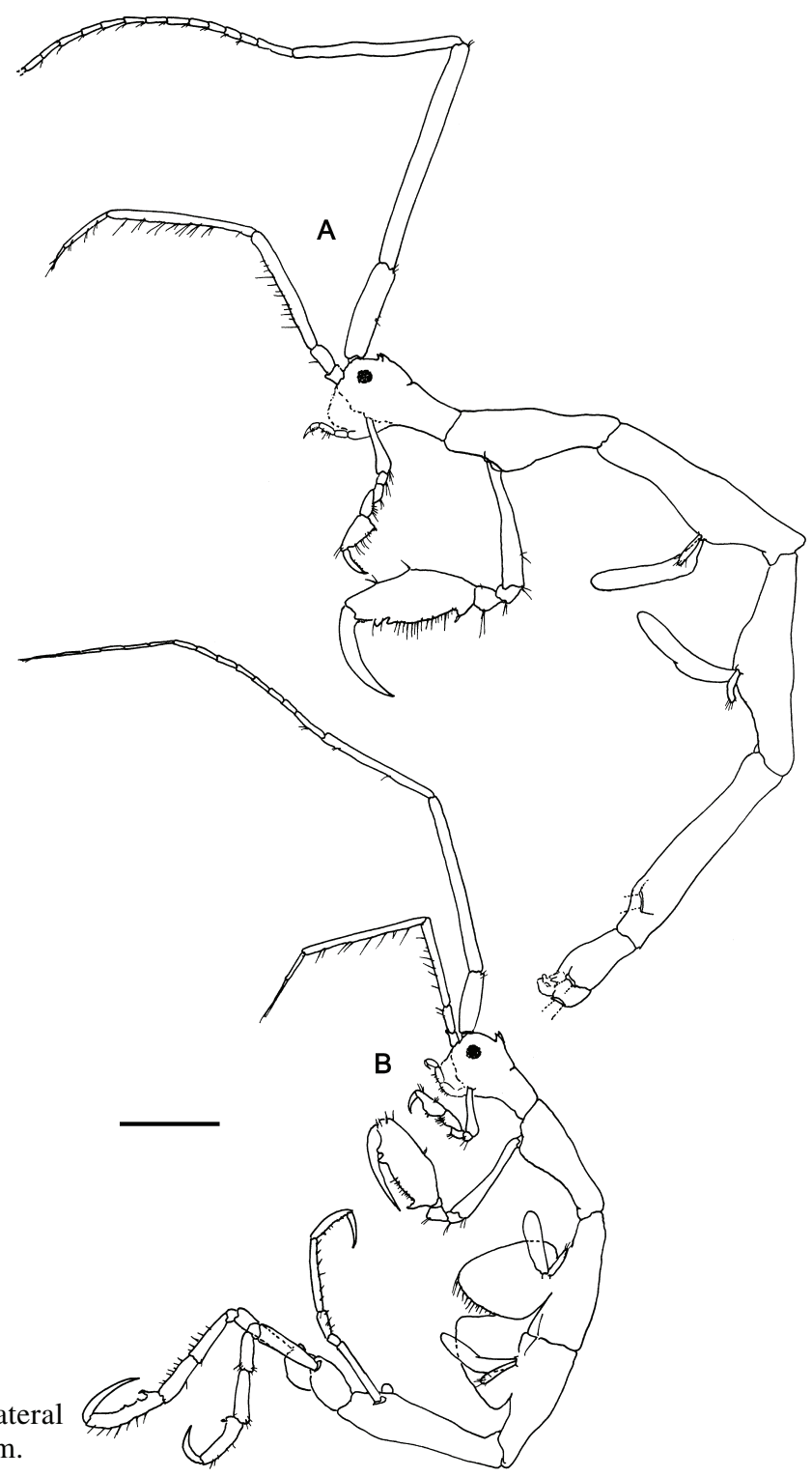

Fig. 45. Orthoprotella australis (Haswell, 1880). Latera view. (A) male; $(B)$ female. (AM P61693). Scale: $1 \mathrm{~mm}$. 
Orthoprotella mayeri Barnard, 1916

Fig. 46

Orthoprotella sp. Mayer, 1903: 36, pl. 1: figs. 25-26, pl.6: figs. 43-44, 46, pl. 9: fig. 15.

Orthoprotella mayeri Barnard, 1916: 284-285; Laubitz, 1991: 118, fig. 14.

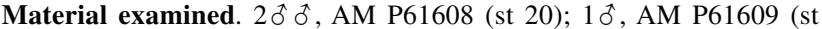
23); 1 ऊิ, AM P61607 (st 30); 1 ㅇ, (QLD 1570).

Remarks. Orthoprotella mayeri was figured recently by Laubitz (1991) based on specimens from New Caledonia.

Distribution. South Africa (Barnard, 1916); Sydney, Australia; Singapore, Malaysia (McCain \& Steinberg, 1970); New Caledonia (Laubitz, 1991); a new record for Queensland, Australia.

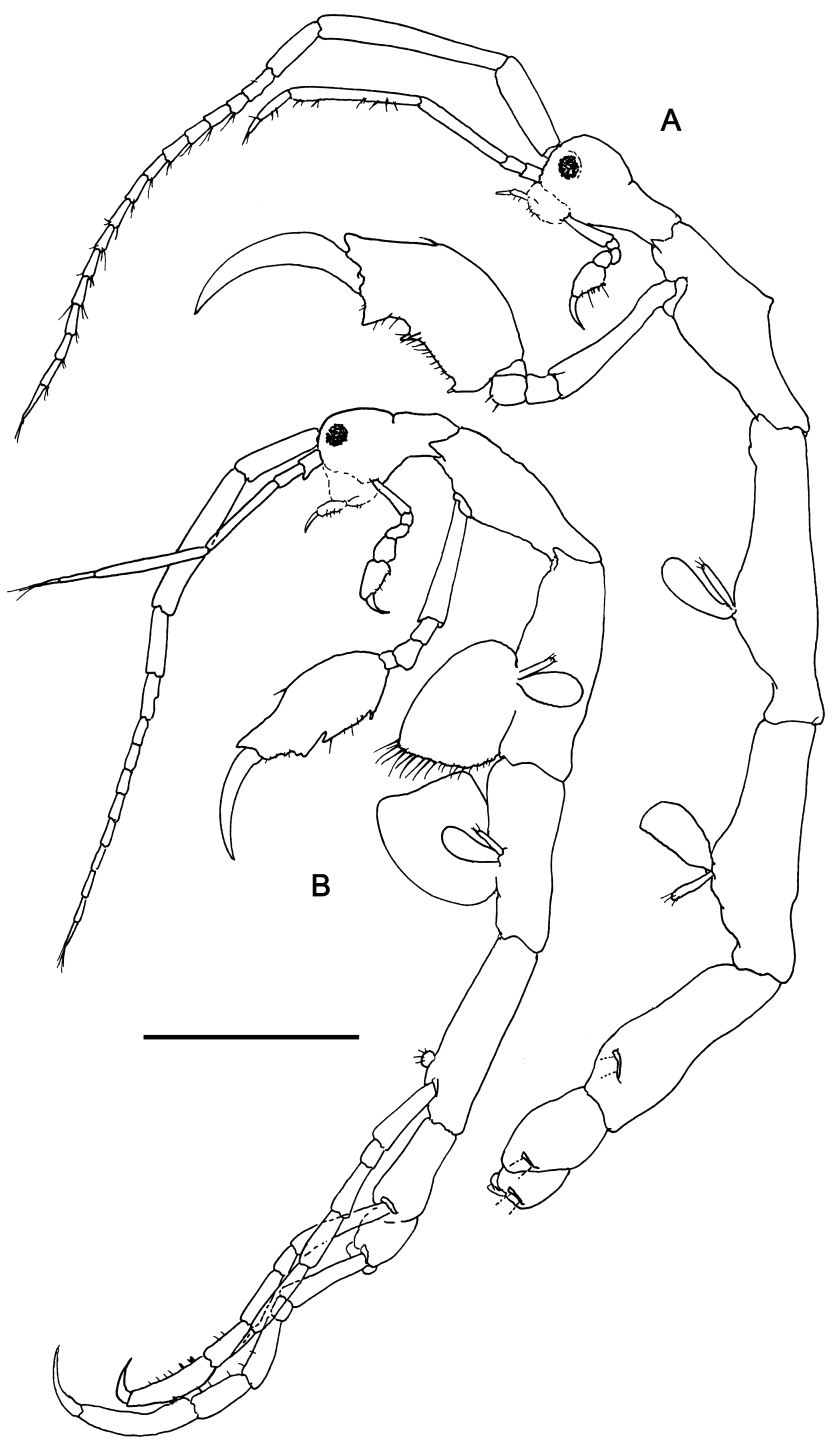

Fig. 46. Orthoprotella mayeri Barnard, 1916. Lateral view. (A) male (AM P61608); (B) female (QLD 1570). Scale: $1 \mathrm{~mm}$.

\section{Orthoprotella pearce n.sp.}

Figs 47-51

Type material. HoLOTYPE $\widehat{o}$, AM P61740, Pidgin Point, Lizard Island, Queensland, on hydroid Halopteris buskii, 5-10 m, QLD 1580, J.M. Guerra-García \& S.J. Keable, 18 Oct 2001. PARATYPES: 1 \& , AM P61741, type locality; 5 ठิ $\widehat{\partial}, 2 q+q, 4$ juveniles, AM P61742, type locality; $2 q \circ$, 1 juvenile, AM P61743, Coconut Beach, Lizard Island, Queensland, on hydroid Macrorhynchia philippina, 4 m, QLD 1474, J.M. Guerra-García \& S.J. Keable, 8 Oct 2001.

Etymology. This species is dedicated to Marianne and Lance Pearce, the accommodation and maintenance officers of Lizard Island Research Station, for help, encouragement and hospitality during the field study at Lizard Island; used as a noun in apposition.

Diagnosis. A pair of anterolateral projections on pereonites 2-4 in males and 2-3 in females. Distal article of the mandibular palp with a setal formula $1-\mathrm{x}-1$, being $\mathrm{x}=7$. Distal projection of the third article of maxilliped palp absent. Pereopods 3 and 4 uniarticulate. A pair of 2-articulate abdominal appendages in males.

\section{Description}

Holotype male. • Body length. 5.6 mm. $\bullet$ Lateral view (Figs 47A). Body smooth except for three pairs of lateral acute projections on pereonites $2-4$. Pereonites 3 and 4 subequal in length; pereonite 7 the shortest. • Gills (Fig. 47A). Present on pereonites 3-4, elongate, length almost 3 times width. - Mouthparts. Upper lip (Fig. 48B) symmetrically bilobed, not setose apically. Mandibles (Fig. 49A,B) with 3-articulate palp; distal article of palp with nine setae following the formula $1-\mathrm{x}-1$, being $\mathrm{x}=7$; second article of the palp with three setae on the right mandible (Fig. 49A) and two setae on the left mandible (Fig. 49B); mandibular molar present, bordered by robust teeth; left mandible with incisor 5toothed, lacinia mobilis 5-toothed followed by three plumose setae; incisor of right mandible 5-toothed, lacinia mobilis serrate, followed by two plumose setae; molar flake present on right mandible with short setulae distally. Lower lip (Fig. 48C) with inner lobes clearly smaller than outer lobes, well demarcated; inner and outer lobes smooth. Maxilla 1 (Fig. 48D) outer lobe with seven robust setae, serrate laterally; distal article of palp with four apical robust setae and a row of four setae medially. Maxilla 2 (Fig. 48E) inner lobe with six setae distally; outer, about 1.3 times as long as inner lobe, with six apical setae. Maxilliped (Fig. 48A) inner plate rectangular with one nodular robust and short setae and three simple setae; outer plate large, about 3 times as long as inner plate, with one acute seta apically and six setae laterally; margin distally crenulated; palp fourarticulate, setose, dactylus with rows of setulae. $\bullet$ Antennae. Antenna 1 (Fig. 50A) about $2 / 3$ body length; distal article of the peduncle short, about $1 / 3$ length of preceding article; flagellum 13 -articulate. Antenna 2 (Fig. 50B) about half width of antenna 1 ; swimming setae absent; proximal article of the peduncle with a distal projection; flagellum 2articulate. • Gnathopods. Gnathopod 1 (Fig. 50C) basis as long as ischium, merus and carpus combined; merus and carpus setose; propodus setose, length about 1.5 times width, palm with a row of minute setulae proximally, one pair of grasping spines, followed by a row of five smaller grasping 


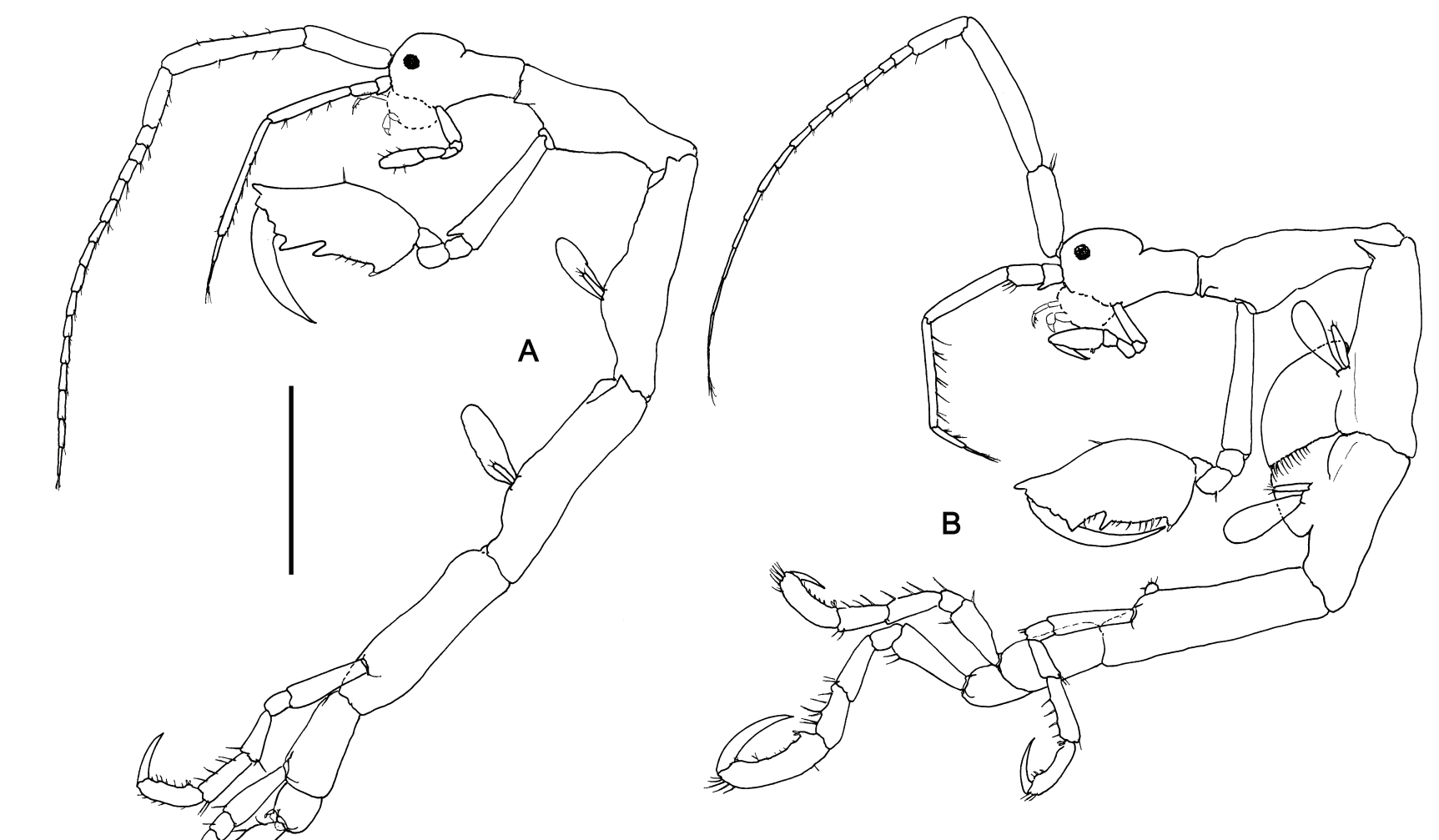

Fig. 47. Orthoprotella pearce n.sp. Lateral view. (A) holotype male (AM P61740); (B) paratype female (AM P61741). Scale: $1 \mathrm{~mm}$.

spines and four setae; dactylus with a dorsal setae proximally and two lateral setae on the distal end, which is divided. Gnathopod 2 (Fig. 50D) inserted on the anterior part of pereonite 2 (Fig. 47A); basis about $3 / 4$ as long as pereonite 2 , with acute distal projection; ischium rectangular with a small rounded projection; merus rounded; carpus triangular; propodus about 1.2 times as long as basis, with acute distal projection dorsally, palm provided with one grasping spine proximally, followed by several setae and U-notch; dactylus elongate and curved, smooth. Pereopods. Pereopods 3 and 4 reduced (Fig. 51A,B) about $1 / 3$ as long as gills, onearticulate, provided with five setae. Pereopods 5-7 (Fig. 51C-E) six articulate, palm of the propodus with a pair of grasping spines. $\bullet$ Penes. (Fig. 51F) Small, rounded, as long as wide. $\bullet$ Abdomen. (Fig. 51F) With a pair of appendages and single dorsal lobe; appendages 2-articulate, positioned on setose peduncles (which are projections of the body); proximal article elongate, with small distal setulae; distal article about $1 / 5$ as long as proximal article, with two apical setae; dorsal lobe with two plumose setae.

Paratype female. $\bullet$ Body length $5.4 \mathrm{~mm}$. Lateral projections on pereonite 4 lacking (Fig. 47B). Oostegites on pereonite 3 setose, on pereonite 4 not setose (Fig. 47B). Gnathopod 2 similar to male (Fig. 50E). Abdomen (Fig. 51G) without appendages.

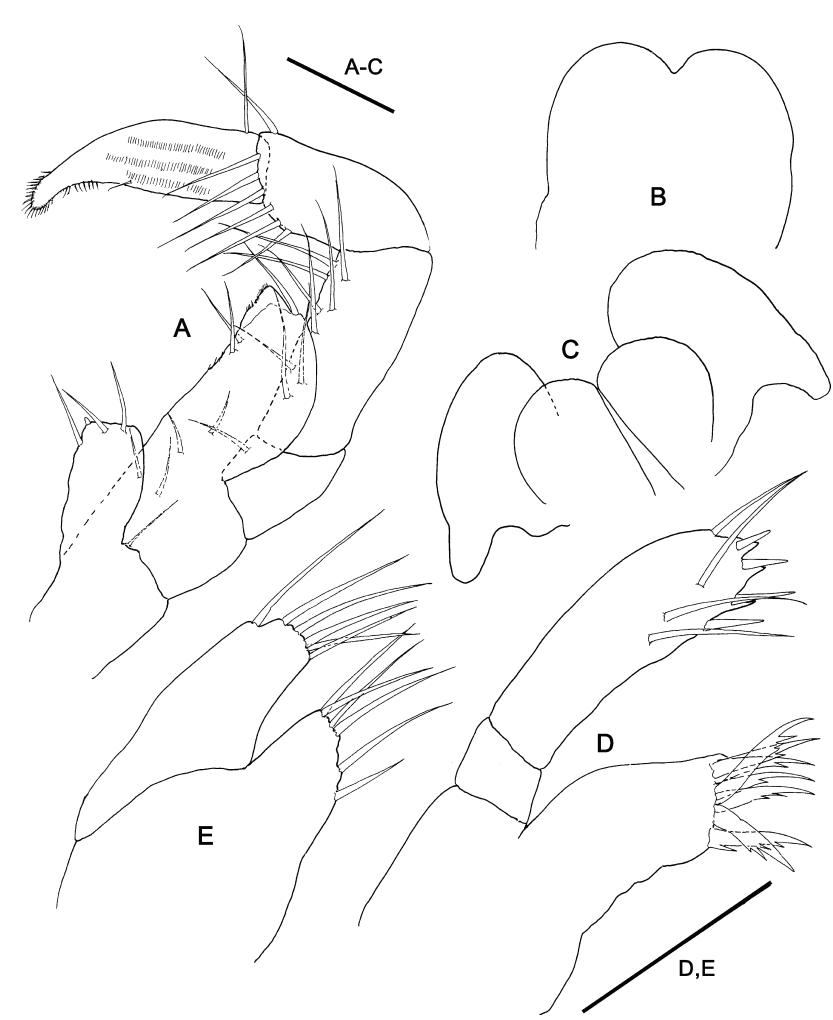

Fig. 48. Orthoprotella pearce n.sp. Holotype male (AM P61740). $(A)$ maxilliped; $(B)$ upper lip; $(C)$ lower lip; $(D)$ maxilla $1 ;(E)$ maxilla 2. Scales $0.05 \mathrm{~mm}$. 


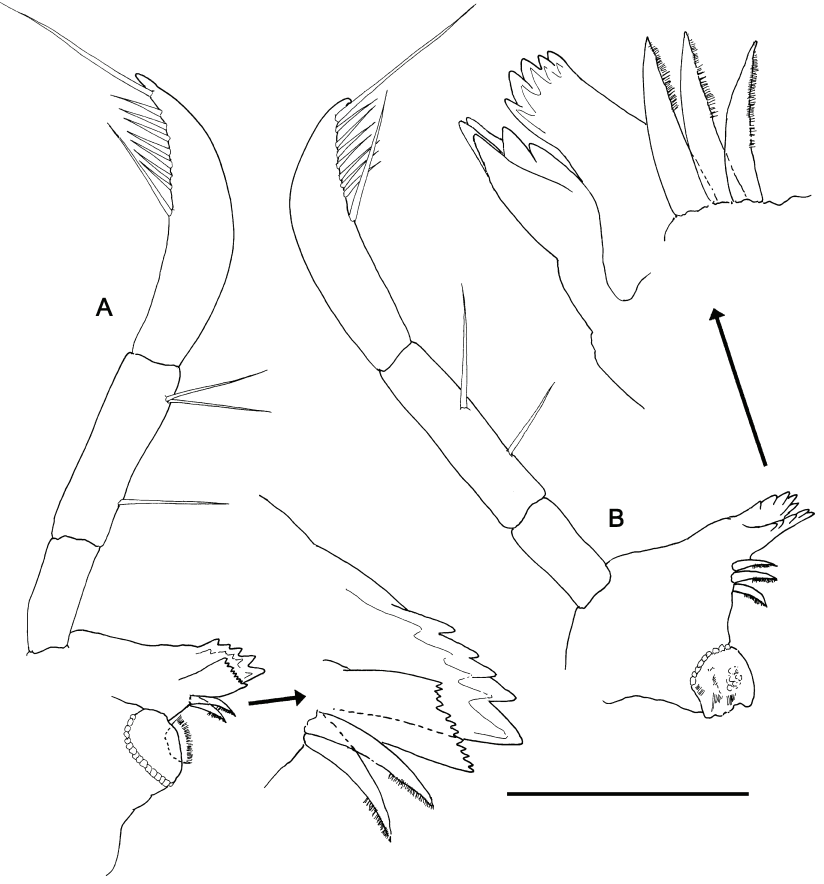

Fig. 49. Orthoprotella pearce n.sp. Holotype male (AM P61740). $(A)$ right mandible; $(B)$ left mandible mandible. Scale: $0.1 \mathrm{~mm}$.

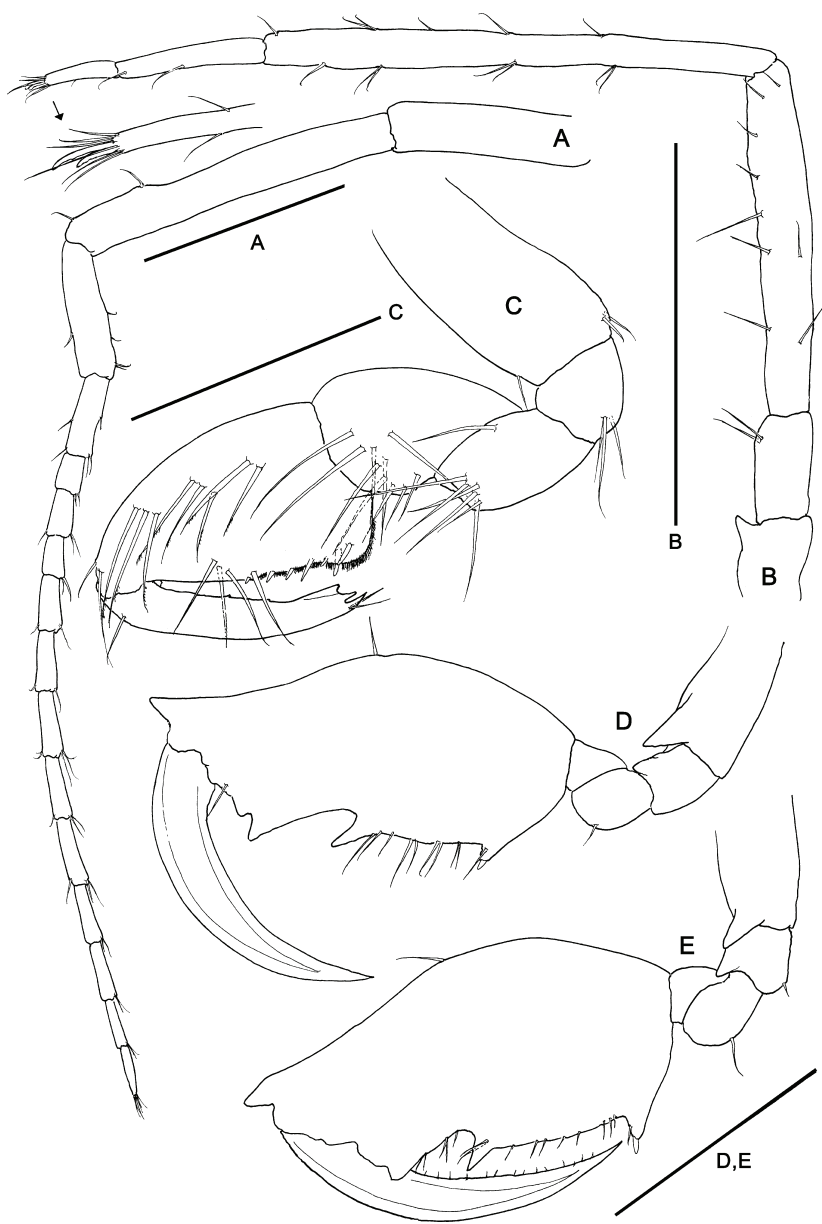

Fig. 50. Orthoprotella pearce n.sp. $(A-D)$ holotype male (AM P61740). (A) antenna 1; $(B)$ antenna 2; $(C)$ gnathopod $1 ;(D)$ gnathopod $2 ;(E)$ paratype female (AM P61741) gnathopod 2. Scales: A,B,D,E: $0.5 \mathrm{~mm}$; C: $0.2 \mathrm{~mm}$.

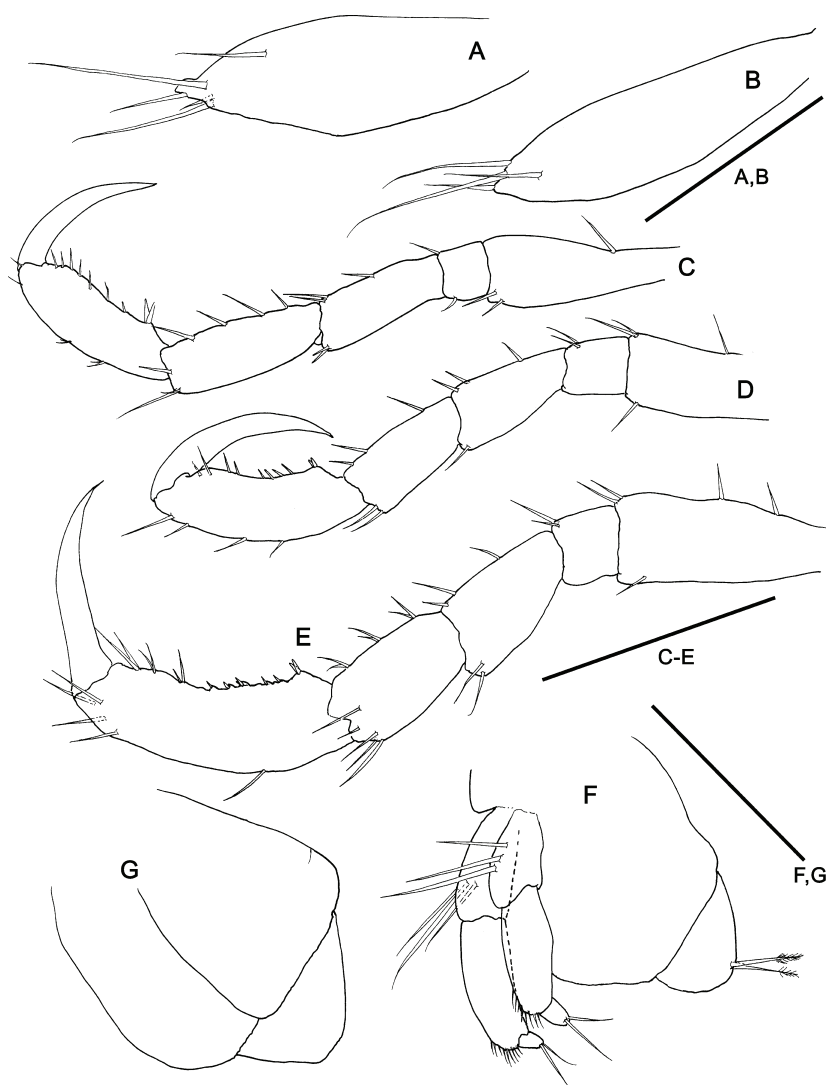

Fig. 51. Orthoprotella pearce n.sp. $(A-F)$ holotype male (AM P61740). (A) pereopod 3; $(B)$ pereopod 4; $(C)$ pereopod 5; $(D)$ pereopod 6; $(E)$ pereopod 7; $(F)$ abdomen (lateral view); $(G)$ paratype female (AM P61741) abdomen (ventral view). Scales: $A, B, F, G: 0.1 \mathrm{~mm} ; C, D: 0.5 \mathrm{~mm}$.

Remarks. The new species of Orthoprotella is close to $O$. mayeri and they can be distinguished only with observation of the lateral view and careful examination of the mouthparts. Orthoprotella mayeri presents the pereopods 3 and 4 as 2 -articulate, although the distal article is tiny and difficult to detect, whilst in $O$. pearce these pereopods are uni-articulate. In connection with the mouthparts, the distal article of the mandibular palp in $O$. mayeri presents a setal formula $1-x-y-1$ being $x>20$ and $y=2-4$, while the formula in $O$. pearce is $1-\mathrm{x}-1$ with $\mathrm{x}=7$; furthermore, the distal projection of the third article of the maxilliped palp, present in $O$. mayeri, is absent in $O$. pearce.

Distribution. Presently known only from Lizard Island, Queensland. 


\section{Paracaprella Mayer, 1890}

\section{Paracaprella sp.}

Fig. 52

Material examined. 1 premature female, AM P61633 (QLD 659); 2 premature females, AM P61634 (QLD 658); 1 \%, AM P61646 (QLD 921); 2 juveniles, AM P61825, Lucinda, Queensland, $18^{\circ} 31^{\prime} \mathrm{S} 146^{\circ} 19^{\prime} \mathrm{E}$, on driftwood on muddy sand flat, P. Colman, 1 Jun 1977.

Remarks. Only females and juveniles have been recorded of this species. The specimens have been assigned to the genus Paracaprella on the basis of the combination of the following features: antenna 2 flagellum 2 -articulate, mandibular palp reduced, molar present, gills on pereonites 3 and 4 , pereopods 3 and 42 -articulate and pereopods 5-7 six-articulate. Species level identification was not possible owing to the absence of male specimens.

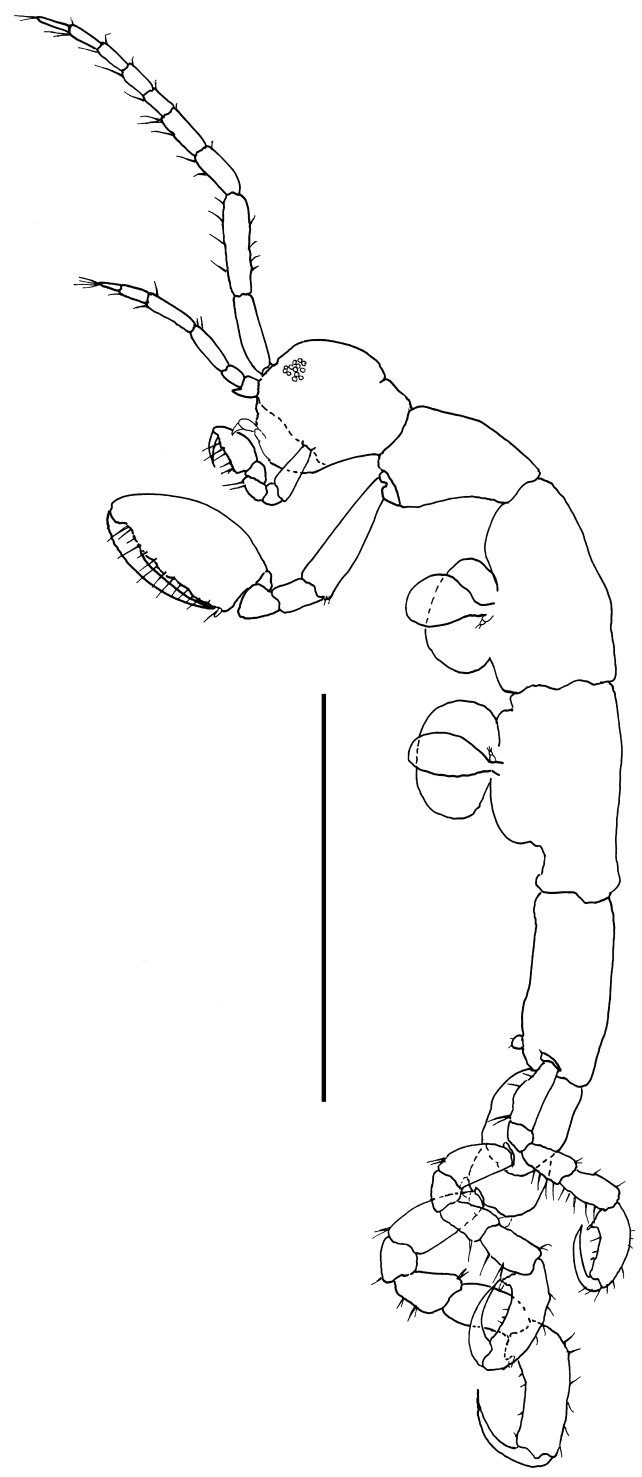

Fig. 52. Paracaprella sp. Premature female (AM P61633), lateral view. Scale: $1 \mathrm{~mm}$.

\section{Protella Dana, 1852}

\section{Protella similis Mayer, 1903}

Fig. 53

Protella similis Mayer, 1903: 34-35, pl. 1: figs. 19-22, pl. 6: figs. 41-42; Laubitz, 1991: 119, fig. 16; Guerra-García, 2002b: 227-229, figs. 13-16.

Material examined. 1 9 , AM P32305 (GBR 7); >20 specimens, AM

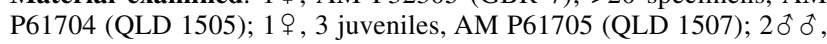
AM P61706 (QLD 1511); >20 specimens, AM P61707 (QLD 1525); 2 우, AM P61708 (QLD 1527); >20 specimens, AM P61709 (QLD 1546); >20 specimens, AM P61710 (QLD 1547); >20 specimens, AM P61711 (QLD 1579).

Remarks. Laubitz (1991) figured the species based on Philippine material, and Guerra-García (2002b) redescribed and figured in detail a female collected from Tanzania. The specimens examined from Lizard Island are in agreement with previous descriptions. As with Orthoprotella australis, although the species seems uncommon on the Great Barrier Reef, it can be locally abundant living mainly on hydroids.

Distribution. Indonesia (Mayer, 1903); Philippines (Laubitz, 1991); Tanzania (Guerra-García, 2002b); a new record for Australia.

\section{Pseudaeginella Mayer, 1890}

\section{Pseudaeginella biscaynensis (McCain, 1968)}

Fig. 54

Fallotritella biscaynensis McCain, 1968: 58-61, figs. 27-28, 53.-McCain \& Steinberg, 1970: 51.-Gable \& Lazo-Wasem, 1987: 637-638.

Pseudaeginella biscaynensis.—Laubitz, 1995: 88.

Type material. HoLOTYPE ô. USNM 120179, Bear Cut, Key Biscayne, Florida, $2 \mathrm{~m}$. Allotype female, USNM 120180, type locality. PARATYPES:

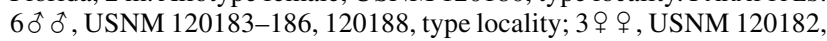
120187, type locality.

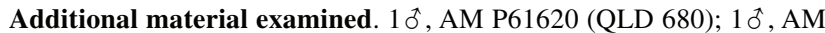
P61621 (QLD 734); 1 우, AM P61623 (QLD 759); 20 के, AM P61622

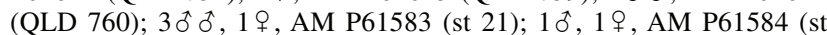
36); 3 ㅊㅎ, 6 우 ㅇ, 4 juveniles, AM P61585 (st 14); 1 , AM P61586 (st 8); 1 ठ , AM P61689 (BK-114); 1 premature female, AM P61688 (BK126); 1 premature female, AM P61690 (QLD 1476).

Remarks. Recently, Laubitz (1995) considered Fallotritella to be synonymous with Pseudaeginella, based mainly on the presence of minute pereopods 3 and 4 also in Pseudaeginella. Consequently, P. biscaynensis, $P$. montouchetti and $P$. polynesica, previously placed in Fallotritella, were transferred to Pseudaeginella. The Queensland specimens agree with the type material from Florida, apart from differences in body projections and pereopod 5. The specimens from Queensland have a more robust pereopod 5 and are considerably less spinose than the type specimens. Nevertheless, the type material shows a considerable degree of morphological variability and consequently the present specimens of Pseudaeginella are assigned to $P$. biscaynensis. Pseudaeginella biscaynensis, known from the Florida coast and vicinity, has also been recently recorded in the Indian Ocean (Guerra-García, 2002b). Hence, the species is probably cosmopolitan but 


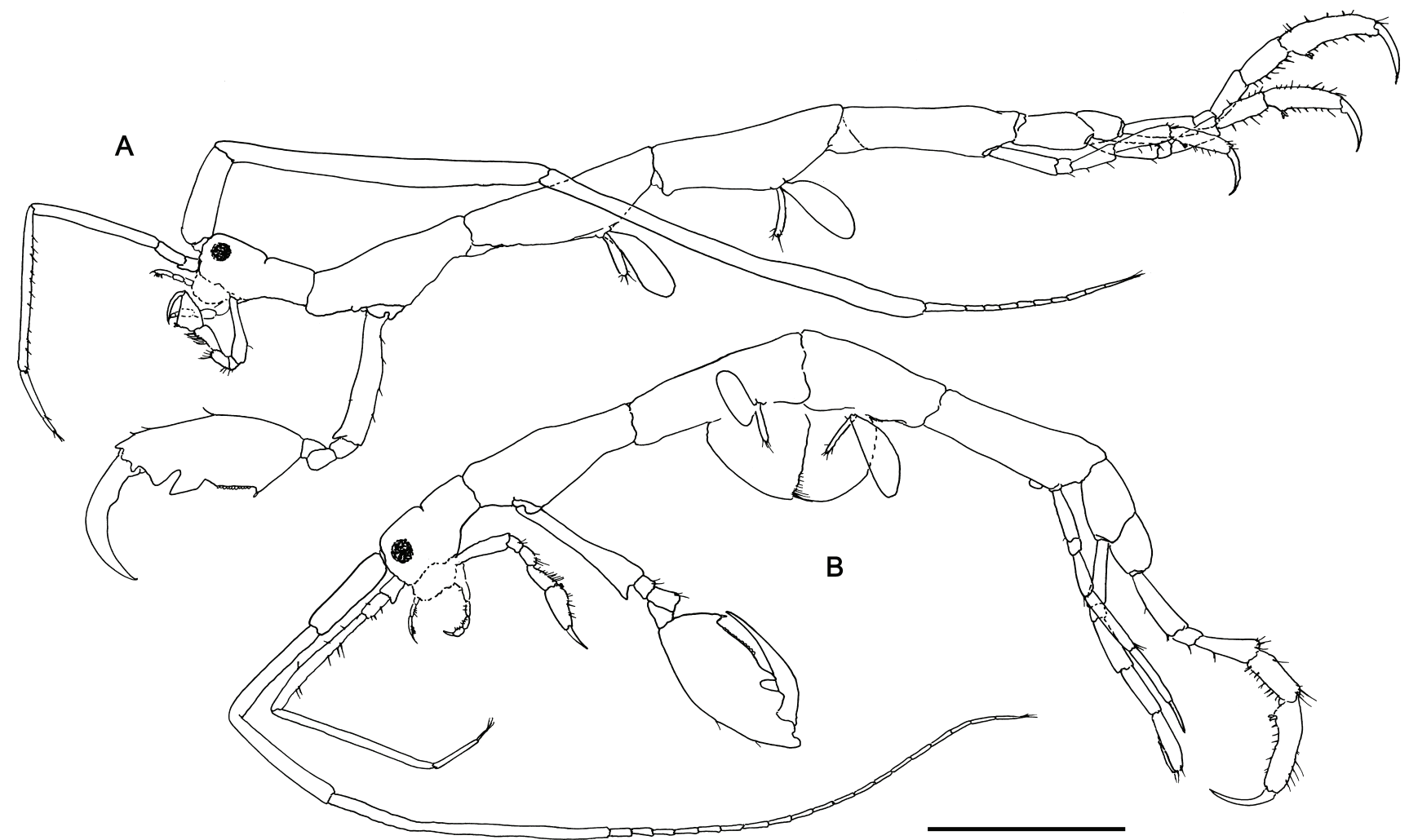

Fig. 53. Protella similis Mayer, 1903. Lateral view. (A) male; (B) female. (AM P61707). Scale: 1 mm.

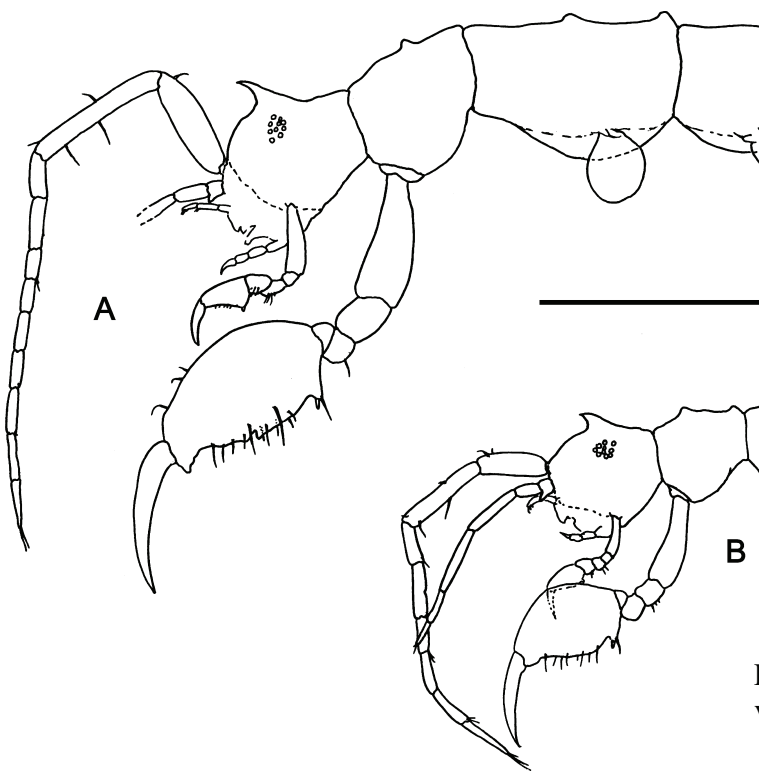

the general paucity of worldwide records probably owes to its small body size and usual detritus covering. Nevertheless, it remains that $P$. biscaynensis may prove to be a species complex. This problem is rather common in the Caprellidae (e.g., Caprella penantis, Caprella scaura, Metaprotella sandalensis). Further study of these species is required.
Distribution. Bear Cut, Key Biscayne, Florida; Bermuda; Soldier Key, Key Largo and Long Key, Florida; Tortugas; Barbuda; Pigem Island, Santa Lucia (McCain, 1968; Gable \& Lazo-Wasem, 1987); Tanzania (Guerra-García, 2002b); and Papua New Guinea (Guerra-García, 2003); a new record for Australia. 


\section{Field study at Lizard Island}

Habitat use. The semi-qualitative abundance of caprellids found at Lizard Island in each habitat is summarized in Table 1. The caprellids, although present in the majority of the samples collected, were not abundant in coral habitats of Lizard Island. Only the hydroids and the sediments presented high values of richness and abundances of the Caprellidae.

Metaprotella sandalensis and Quadrisegmentum triangulum were the most common species around the Island, being present in the majority of substrates on both hard and soft bottoms. Conversely, the majority of the species were found only in specific habitats. Pseudaeginella biscaynensis, Hemiaegina minuta, Orthoprotella mayeri, and Orthoprotella pearce n.sp. were found only on hydroids. Metaproto novaehollandiae, Perotripus keablei n.sp., Protogeton inflatus and Pseudoprellicana johnsoni were restricted to sediments and/or coral rubble. Aciconula australiensis, Pseudoproto fallax and Jigurru vailhoggett were found clinging to the algal turf growing on dead hard corals. The cluster analysis based on the habitat use showed different groups of species (Fig. 55).

Recently Guerra-García (2001) conducted a similar ecological study in Ceuta, North Africa, a temperate enclave in the Strait of Gibraltar. With a coastline of about $20 \mathrm{~km}$, Ceuta is approximately the same size as Lizard Island. The benthic communities around Ceuta, as of a typical temperate region, are dominated by algae beds in the shallow waters (instead of corals, which are dominant in the tropics) and hydroids, gorgonians, sponges and ascidians in the deeper areas (see Guerra-García, 2001). Guerra-García (2001) collected samples of different substrates along the coast of Ceuta (algae, hydroids, sponges, gorgonians, bryozoans, ascidians and sediments). A summary of the data is given in Table 2. Comparison of data from Ceuta with that of Lizard Island indicates that the number of species is similar in both regions (22 species in Ceuta, 16 species in Lizard Island). Nevertheless, in spite of similar species richness, there are important differences in the caprellid community between the two localities: $(a)$ at Ceuta the species are distributed in only 5 genera with most in Caprella, whereas at Lizard Island 13 genera are represented, none of which belong to Caprella; (b) although caprellids are frequent in both areas, the abundance values are clearly higher at Ceuta than at Lizard Island; $(c)$ the highest species richness and abundance of caprellids was found on algae and hydroids at Ceuta whereas caprellids are practically absent on the algae from Lizard Island. Although the algae species differ between temperate and tropical regions, species with similar morphology are found in both places. In spite of collecting 45 algal samples comprising 20 species around Lizard Island, only two caprellid species were found: Mayericaprella sandalensis and Q. triangulum, being the most common species found on all substrates along the coral reef system. The reason for this distribution is not clear. The different degree of algae cover in both systems might be involved: the algae cover is much higher in temperate than tropical regions, which are instead dominated by corals. Nevertheless, the hydroid cover is not so high on coral reefs, although the hydroids registered the highest species richness and abundance of the Caprellidae. Perhaps the activity of predators could be significantly different. Caprellids are considered important prey for many fish species (Caine, $1987,1989,1991)$ and the abundance of fishes in tropical areas is high. Taking into account that many of the coral reef hydroids are stinging species, it would be possible that the caprellids use hydroid habitats as a protection instead of using algae where they are potentially less protected from fish predators. This could explain the general low abundance of caprellids on coral reefs but the specific higher abundances registered on the stinging hydroids. Future studies are necessary to elucidate ecological patterns and habitat preferences of the Caprellidae along the coral reef systems of tropical areas.

Distribution of the Caprellidae around Lizard Island. Guerra-García \& García-Gómez (2001) showed that the caprellid community at Ceuta could be used as a bioindicator of environmental conditions because the distribution of caprellids is highly influenced by physico-chemical factors such as hydrodynamics. In the present study, using multivariate analysis, when comparing the caprellid fauna in the different sites around the island (Table 3), found no clear differences between the west and the east coast (Fig. 56). Although MDS seems to separate the two groups of

\section{Similarity (Bray Curtis)}

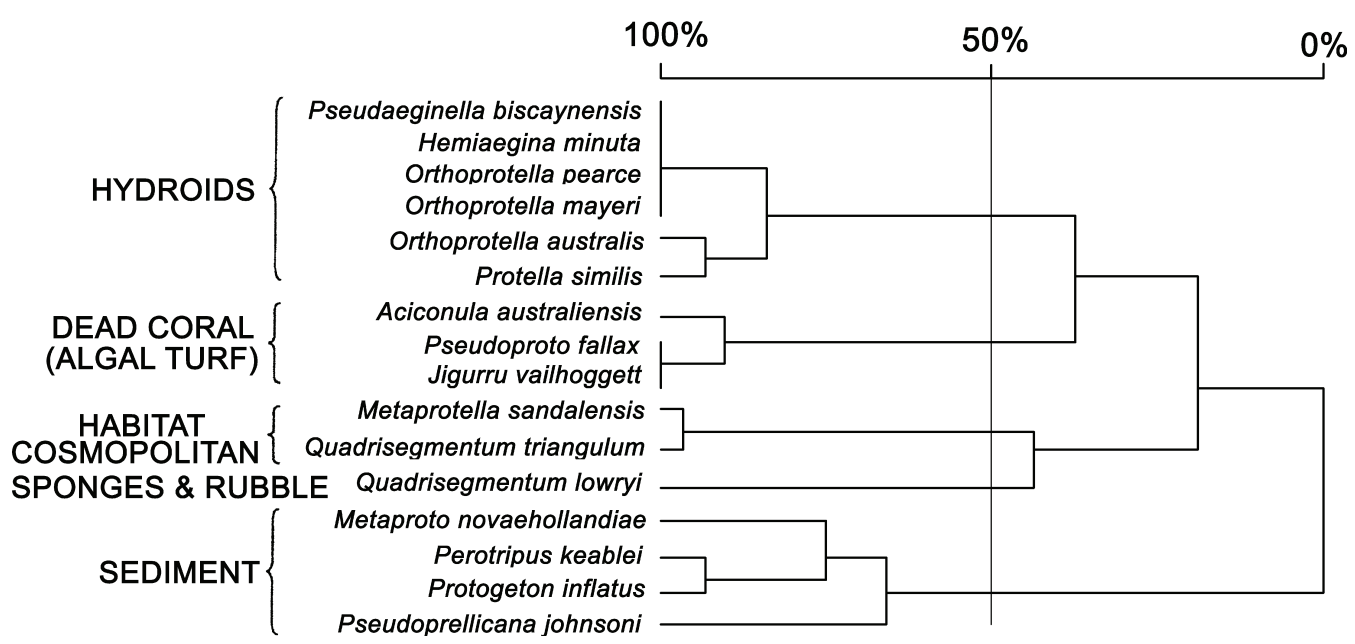

Fig. 55. Dendrogram of similarity between the different caprellid species in base of the habitat preferences (see Table 1). 
Table 2. Species composition of the Caprellidae from Ceuta, northern Africa (temperate region). The qualitative values of abundance of caprellids in the different habitats are included. Qualitative scale: white, absent; $\bullet^{\text {rare }}(1-10$ individuals/sample); $\bullet \bullet$ common (10$100 \mathrm{ind} / \mathrm{sample}) ; \bullet \bullet$ very common (>100 ind/sample). Information taken from Guerra-García (2001).

\begin{tabular}{|c|c|c|c|c|c|c|c|c|c|}
\hline & $\frac{\mathbb{E}}{\tilde{\sigma}}$ & 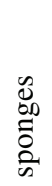 & 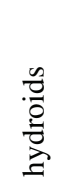 & 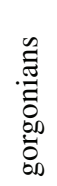 & 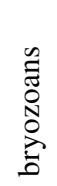 & 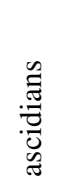 & 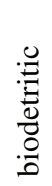 & $\begin{array}{l}\vec{D} \\
\overline{0} \\
\frac{0}{\infty} \\
0 \\
0 \\
0 \\
0\end{array}$ & 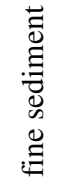 \\
\hline Caprella acanthifera Leach, 1814 & $\bullet \bullet$ & $\bullet$ & $\bullet$ & $\bullet$ & $\bullet$ & $\bullet$ & $\circ$ & $\bullet$ & $\circ$ \\
\hline C. acanthifera discrepans (see Krapp-Schickel \& Vader, 1998) & $\bullet$ & ० & $\bullet$ & $\circ$ & $\circ$ & $\bullet$ & $\circ$ & ○ & $\circ$ \\
\hline C. cavediniae Krapp-Schickel \& Vader, 1998 & o & ० & $\bullet$ & $\circ$ & $\circ$ & $\circ$ & $\circ$ & $\circ$ & $\circ$ \\
\hline C. ceutae Guerra-García \& Takeuchi, 2002 & $\circ$ & o & $\bullet$ & $\circ$ & $\circ$ & $\circ$ & $\circ$ & ○ & $\circ$ \\
\hline C. danilevskii Czerniavskii, 1868 & $\bullet \bullet \bullet$ & ० & $\circ$ & $\circ$ & $\circ$ & $\circ$ & $\circ$ & ○ & $\circ$ \\
\hline C. dilatata Kröyer, 1843 & $\bullet$ & $\circ$ & $\circ$ & $\circ$ & $\circ$ & $\circ$ & $\circ$ & $\circ$ & $\circ$ \\
\hline C. erethizon Mayer, 1901 & $\circ$ & $\circ$ & $\bullet$ & o & $\circ$ & $\bullet$ & $\circ$ & ○ & $\circ$ \\
\hline C. fretensis Stebbing, 1878 & $\bullet$ & ० & $\circ$ & $\circ$ & $\circ$ & $\circ$ & $\circ$ & $\circ$ & $\circ$ \\
\hline C. grandimana Mayer, 1882 & $\bullet$ & ० & $\circ$ & $\circ$ & $\circ$ & $\circ$ & $\circ$ & $\circ$ & $\circ$ \\
\hline C. hirsuta Mayer, 1890 & $\bullet$ & $\circ$ & $\circ$ & $\circ$ & ○ & $\circ$ & $\circ$ & $\circ$ & $\circ$ \\
\hline C. liparotensis Haller, 1879 & $\bullet \bullet$ & ० & $\bullet$ & $\circ$ & $\circ$ & $\circ$ & $\circ$ & $\circ$ & $\circ$ \\
\hline C. monai Guerra-García, Sánchez-Moyano \& García-Gómez, 2001 & $\circ$ & ○ & $\bullet$ & $\circ$ & $\circ$ & $\circ$ & $\circ$ & $\circ$ & $\circ$ \\
\hline C. penantis Leach, 1814 & $\bullet \bullet$ & $\circ$ & $\bullet$ & ○ & $\circ$ & $\circ$ & $\circ$ & $\bullet$ & $\circ$ \\
\hline C. sabulensis Guerra-García, Sánchez-Moyano \& García-Gómez, 2001 & $\circ$ & ○ & ○ & $\circ$ & $\circ$ & $\circ$ & $\bullet$ & ○ & $\circ$ \\
\hline C. santosrosai Sánchez-Moyano, Jiménez-Martín \& García-Gómez, 1995 & $\circ$ & $\bullet$ & $\bullet \bullet \bullet$ & $\bullet$ & $\circ$ & $\circ$ & $\circ$ & $\circ$ & $\circ$ \\
\hline C. takeuchii Guerra-García, Sánchez-Moyano \& García-Gómez, 2001 & $\bullet$ & ० & $\circ$ & $\circ$ & $\circ$ & $\circ$ & $\circ$ & $\circ$ & $\circ$ \\
\hline C. tuberculata Bate \& Westwood, 1868 & $\circ$ & $\circ$ & $\bullet$ & $\circ$ & $\circ$ & $\circ$ & $\circ$ & $\circ$ & $\circ$ \\
\hline Pariambus typicus Kröyer, 1844 & $\circ$ & ○ & ○ & $\circ$ & $\circ$ & $\circ$ & $\bullet$ & $\bullet$ & $\bullet \bullet \bullet$ \\
\hline Pedoculina garciagomezi Sánchez-Moyano, Carballo \& Estacio, 1995 & $\bullet$ & ○ & $\circ$ & $\circ$ & $\circ$ & $\circ$ & $\circ$ & $\circ$ & $\circ$ \\
\hline Phtisica marina Slabber, 1769 & $\bullet \bullet \bullet$ & $\bullet$ & $\bullet$ & $\bullet \bullet$ & $\bullet \bullet$ & $\bullet \bullet$ & $\bullet$ & $\bullet \bullet$ & $\bullet \bullet \bullet$ \\
\hline Pseudoprotella inermis Chevreux, 1927 & $\circ$ & $\circ$ & $\bullet$ & $\circ$ & $\circ$ & $\circ$ & $\circ$ & $\circ$ & $\circ$ \\
\hline P. phasma (Montagu, 1804) & $\bullet \bullet$ & $\circ$ & $\bullet \bullet$ & $\bullet$ & $\circ$ & $\circ$ & $\circ$ & $\bullet$ & $\bullet$ \\
\hline
\end{tabular}

stations according to the caprellid composition, this ordination is not clear in the dendrogram of the Cluster analysis (Fig. 56).

These results could indicate that environmental conditions such as hydrodynamics, silting, and suspended organic matter in the water column are not radically different on both sides of the Island as one might expect from the exposure to the strong winds from the southeast from midMarch to September each year. Although some current speed measurements are given by Leis (1986), a complete study of the environmental conditions of the shallow waters around the Island would be necessary to test whether or not the physico-chemical differences between the west and east coasts are significant.
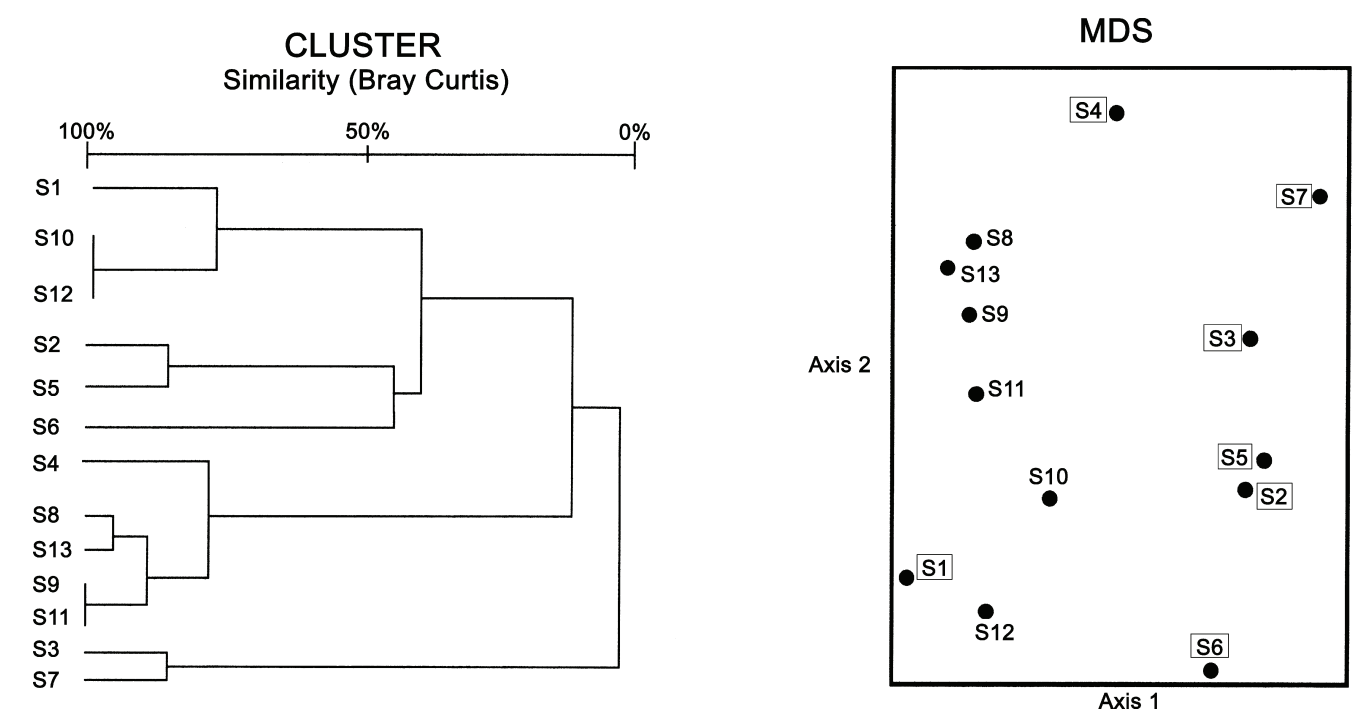

Fig. 56. MDS analysis and dendrogram of similarity between the stations sampled on SCUBA (see Fig. 2) in base of the caprellid composition. 
Table 3. Species compositions of the Caprellidae in the 13 stations sampled on SCUBA at Lizard Island and used for the multivariate analysis of ordenation and classification (Fig. 55). ( $\bullet$, presence; ○, absence).

\begin{tabular}{|c|c|c|c|c|c|c|c|c|c|c|c|c|c|}
\hline & $\mathrm{S} 1$ & $\mathrm{~S} 2$ & S3 & S4 & S5 & S6 & S7 & S8 & S9 & $\mathrm{S} 10$ & S11 & $\mathrm{S} 12$ & $\mathrm{~S} 13$ \\
\hline Aciconula australiensis & o & $\bullet$ & $\bullet$ & ० & $\bullet$ & ० & o & ० & $\circ$ & $\circ$ & $\circ$ & $\circ$ & $\circ$ \\
\hline Hemiaegina minuta & o & $\bullet$ & $\circ$ & ० & $\circ$ & ० & o & ० & ० & $\circ$ & $\circ$ & $\circ$ & $\circ$ \\
\hline Jigurru vailhoggett & o & ० & $\circ$ & ० & $\bullet$ & ० & $\circ$ & ० & ० & $\circ$ & $\circ$ & $\circ$ & $\circ$ \\
\hline Metaprotella sandalensis & $\bullet$ & $\bullet$ & $\bullet$ & o & $\bullet$ & $\bullet$ & $\circ$ & $\bullet$ & $\bullet$ & $\bullet$ & $\bullet$ & $\bullet$ & $\bullet$ \\
\hline Metaproto novaehollandiae & o & $\bullet$ & $\bullet$ & o & o & $\bullet$ & $\bullet$ & o & o & o & ० & o & $\bullet$ \\
\hline Orthoprotella australis & o & o & ० & $\bullet$ & o & $\bullet$ & ० & 0 & o & $\circ$ & o & o & ○ \\
\hline Orthoprotella mayeri & $\circ$ & $\bullet$ & o & ० & o & o & o & o & 0 & o & o & o & o \\
\hline Orthoprotella pearce & $\circ$ & ० & $\circ$ & $\bullet$ & $\bullet$ & ० & $\circ$ & ० & ० & $\circ$ & $\circ$ & $\circ$ & $\circ$ \\
\hline Perotripus keablei & $\circ$ & ० & $\circ$ & ० & $\circ$ & ० & $\bullet$ & ० & ० & $\circ$ & $\circ$ & $\circ$ & $\circ$ \\
\hline Protella similis & $\circ$ & ○ & ० & $\bullet$ & $\circ$ & ○ & $\circ$ & $\bullet$ & $\bullet$ & ○ & $\bullet$ & ○ & $\bullet$ \\
\hline Protogeton inflatus & o & o & o & $\bullet$ & o & o & ० & o & o & o & ○ & o & ○ \\
\hline Pseudaeginella biscaynensis & o & $\bullet$ & $\circ$ & o & $\bullet$ & o & o & o & o & ० & ० & $\circ$ & ० \\
\hline Pseudoprellicana johnsoni & o & ० & $\circ$ & ० & ० & $\bullet$ & o & ० & ० & $\circ$ & $\circ$ & $\circ$ & $\circ$ \\
\hline Pseudoproto fallax & 0 & o & $\bullet$ & 0 & $\bullet$ & o & 0 & o & o & 0 & o & o & $\circ$ \\
\hline Quadrisegmentum lowryi & o & ० & $\circ$ & o & $\circ$ & o & ० & $\bullet$ & ० & $\circ$ & $\circ$ & $\circ$ & $\circ$ \\
\hline Quadrisegmentum triangulum & $\circ$ & $\bullet$ & $\bullet$ & $\bullet$ & $\bullet$ & o & $\bullet$ & $\bullet$ & $\bullet$ & $\bullet$ & $\bullet$ & ○ & o \\
\hline
\end{tabular}

ACKNOWLEDGMents. I am very grateful to P.B. Berents, Australian Museum, for making collections available for study and for her kindness and hospitality during my stay at the Australian Museum. I would especially like to thank S.J. Keable, Australian Museum, for his help, encouragement, advice and friendship during my stay at the Australian Museum and for his valuable assistance during the sampling at Lizard Island; this work is dedicated to him. I thank Anne Hoggett and Lyle Vail, directors of the Lizard Island Research Station (LIRS), and Marianne and Lance Pearce, LIRS accommodation and maintenance officers, for their hospitality, help and facilities provided during the fieldwork at LIRS. Thanks to R. Johnson, Australian Museum, for patiently registering the material in the collections of the AM and for his help and friendship during my stay in the Australian Museum. I also thank J. Short and P. Davie for the loan of the unidentified material from Queensland Museum. Thanks to E. Nelson (National Museum of Natural History, Smithsonian Institution), J. Olesen (Zoological Museum, Copenhagen) and D. Platvoet (Zoologisch Museum, Amsterdam) for the loan of type specimens. I am very grateful to S. Ahyong, Australian Museum, for his valuable comments to a preliminary version of the manuscript. The stay at the Australian Museum was supported by a grant AP 9828617065 from the Ministry of Education, Culture and Sport from Spain and the field study at Lizard Island by a Visiting Collection Fellowship from the Australian Museum.

\section{References}

Arimoto, I., 1976. Taxonomic studies of caprellids (Crustacea, Amphipoda, Caprellidae) found in the Japanese and adjacent waters. Special Publications from the Seto Marine Biological Laboratory, Kyoto University Series III: 1-229.

Barnard, K.H., 1916. Contributions to the crustacean fauna of South Africa. The Amphipoda. Annals of the South African Museum 15(3): 105-302.

Barnard, K.H., 1931. Amphipoda. Scientific Report of the Great Barrier Reef Expedition 4: 11-135.

Bate, C.S., \& J.O. Westwood, 1868. Caprellidae. A History of the British Sessile-eyed Crustacea 2: 68-70.

Berents, P.B., 1983. The Melitidae of Lizard Island and adjacent reefs, the Great Barrier Reef, Australia (Crustacea: Amphipoda). Records of the Australian Museum 35(3): 101-143.
Bray, J.R., \& J.T. Curtis, 1957. An ordination of the upland forest communities of Southern Wisconsin. Ecological Monographs 27: $325-349$.

Caine, E.A., 1987. Potential effect of floating dock communities on a South Carolina estuary. Journal of Experimental Marine Biology and Ecology 108: 83-91.

Caine, E.A., 1989. Caprellid amphipod behaviour and predatory strikes by fish. Journal of Experimental Marine Biology and Ecology 126: 173-180.

Caine, E.A., 1991. Caprellid amphipods: fast food for the reproductively active. Journal of Experimental Marine Biology and Ecology 148: 27-33.

Carballo, J.L., S.A. Naranjo \& J.C. García-Gómez, 1996. Use or marine sponges as stress bioindicators in marine ecosystems at Algeciras Bay (southern Iberian Peninsula). Marine Ecology Progress Series 135: 109-122.

Cavedini, P., 1982. Contributo alla conoscenza dei Caprellidi del Mediterraneo (Crustacea, Amphipoda). Bollettino del Museo civico di storia naturale di Verona 8: 493-531.

Chevreux, E., 1927. Crustacés Amphipodes. Expéditions Scientifiques du "Travailleur" et de "Talisman" pendant les annés 1880, 1881, 1882, 1883, Malacostracés 3: 41-152.

Chevreux, E., \& L. Fage, 1925. Amphipodes. Fauna de France 9: $1-488$.

Clarke, K.R., \& R.N. Gorley, 2001. PRIMER (Plymouth Routines In Multivariate Ecological Research) v5: User Manual/Tutorial. PRIMER-E Ltd, Plymouth, 91 pp.

Czerniavski, V., 1868. Materialia ad zoographiam Ponticam comparatam. Travaux de la Société des naturalistes de St. Pétersbourg 1: 19-136.

Dana, J.D., 1852. On the classification of the Crustacea Choristopoda or Tetradecapoda. American Journal of Science and Arts 14: 297-316.

Dougherty, E.C., \& J.E. Steinberg, 1953. Notes on the skeleton shrimps (Crustacea: Caprellidea) of California. Proceedings of the Biological Society of Washington 66: 39-50

Fisk, D.A., 1983. Free-living corals: distributions according to plant cover, sediments, hydrodynamics, depth and biological factors. Marine Biology 74: 287-294.

Gable, M.F., \& E.A. Lazo-Wasem, 1987. The caprellids (Amphipoda: Caprellidea) of Bermuda: a survey of specimens collected from 1876-1987, including cave inhabitants, and the description of Deutella aspiducha, new species. Proceedings of the Biological Society of Washington 100(3): 629-639. 
Guerra-García, J.M., 2001. Habitat use of the Caprellidea (Crustacea: Amphipoda) from Ceuta, North Africa. Ophelia 55(1): 27-38.

Guerra-García, J.M., 2002a. Littoral caprellids (Crustacea: Amphipoda: Caprellidea) from Philippines, with the description of a new species. The Raffles Bulletin of Zoology 50(2): 395-406.

Guerra-García, J.M., 2002b. Redescription of five rare caprellids (Crustacea: Amphipoda: Caprellidea) collected from Tanzanian coasts. Helgoland Marine Research 55: 221-231.

Guerra-García, J.M., 2003. Caprellids (Crustacea: Amphipoda) from Papua New Guinea, with the description of a new species. Helgoland Marine Research 57: 100-109.

Guerra-García, J.M., 2004. The Caprellidea (Crustacea, Amphipoda) from Western Australia and Northern Territory, Australia. Hydrobiologia 522(1-3): 1-74.

Guerra-García, J.M., \& J.C. García-Gómez, 2001. The spatial distribution of Caprellidea (Crustacea: Amphipoda): a stress bioindicator in Ceuta (North Africa, Gibraltar area). P.S.Z.N. Marine Ecology 22(4): 357-367.

Guerra-García, J.M., J.E. Sánchez-Moyano, \& J.C. García-Gómez, 2001. Two new hairy species of Caprella (Amphipoda) from the Strait of Gibraltar, with a redescription of Caprella grandimana. Journal of Crustacean Biology 21: 1014-1030.

Guerra-García, J.M., \& I. Takeuchi, 2002. The Caprellidea (Crustacea: Amphipoda) from Ceuta, North Africa, with the description of three species of Caprella, a key to the species of Caprella, and biogeographical discussion. Journal of Natural History 36(6): 675-714.

Guerra-García, J.M., \& I. Takeuchi, 2004. The Caprellidea (Crustacea: Amphipoda) from Tasmania. Journal of Natural History 38: 967-1044.

Haller, G., 1879. Vorläufige Notizen über die Systematik der im Mittelmeer vorkommenden Caprelliden. Zoologischer Anzeiger 2: 230-233.

Haswell, W.A., 1879. On some additional new genera and species of amphipodous crustaceans. Proceedings of the Linnean Society of New South Wales 4(3): 319-351.

Haswell, W.A., 1880. On some Amphipods from Australia and Tasmania. Proceedings of the Linnean Society of New South Wales 5(1): 97-105.

Haswell, W.A., 1885. Revision of the Australian Laemodipoda. Proceedings of the Linnean Society of New South Wales 6(4): 993-1000.

Hirayama, A., 1988. A ghost shrimp with four-articulate fifth pereopods (Crustacea: Caprellidea: Phtisicidae) from Northwest Australia. Zoological Science 5: 1089-1093.

Jones, A.R., 1984. Sedimentary relationships and community structure of benthic crustacean assemblages of reefassociated sediments at Lizard Island, Great Barrier Reef. Coral Reefs 3: 101-111.

Keable, S.J., 1995. Structure of the marine invertebrate scavenging guild of a tropical reef ecosystem: field studies at Lizard Island, Queensland, Australia. Journal of Natural History 29: 27-45.

Krapp-Schickel, T., 1993. Suborder Caprellidea. In The Amphipoda of the Mediterranean, ed. S. Ruffo. Mémoires de lÍnstitute Oceanographique, Monaco 13(3): 773-809.

Krapp-Schickel, T., \& W. Vader, 1998. What is, and what is not, Caprella acanthifera Leach, 1814 (Amphipoda, Caprellidea)? Part 1: the acanthifera-group. Journal of Natural History 32: 949-967.

Kröyer, H., 1843. Beskrivelse af nogle arter og slaegter af Caprellina: med indledende bemaerkninger om Laemodipoda og deres plads i systemet. Naturhistorisk tidsskrift 4: 585.

Kröyer, H. 1844. Karcinologiske bidrag. Naturhistorisk tidsskrift 2: 290 .
Kruskal, J.B., \& M. Wish, 1978. Multidimensional Scaling. Beverly Hills, California: Sage Publications, 93 pp.

La Follette, R., 1915. Caprellidae from Laguna Beach. Journal of Entomology and Zoology 7: 55-63.

Lamarck, J.B., 1801. Systéme des animaux sans vertèbres ou tableau général des classes, des ordres et des genres de ces animaux. Paris: Deterville, 295 pp.

Larsen, K., 1997. A new species of Metaprotella (Crustacea: Amphipoda: Caprellidea) from east Africa, with key to the genera of Protellidae and discussion of generic characteristics. Journal of Natural History 31: 1203-1212.

Laubitz, D.R., 1970. Studies on the Caprellidae (Crustacea, Amphipoda) of the American North Pacific. National Museum of Natural Sciences, Ottawa, Publications in Biological Oceanography 1: 1-89.

Laubitz, D.R., 1972. The Caprellidae (Crustacea, Amphipoda) of Atlantic and Arctic Canada. National Museum of Natural Sciences, Ottawa, Publications in Biological Oceanography 4: $1-82$.

Laubitz, D.R., 1991. Crustacea Amphipoda Caprellidea: Caprellids from the western Pacific (New Caledonia, Indonesia and the Philippines). In Résultats des Campagnes MUSORSTOM, ed. A. Crosnier, 152: 101-123.

Laubitz, D.R., 1993. Caprellidea (Crustacea: Amphipoda): towards a new synthesis. Journal of Natural History 27: 965-976.

Laubitz, D.R., 1995. Caprellidea (Crustacea: Amphipoda) from the Southern and Western Indian Ocean. Mésogée 54: 81-100.

Leach, W.E., 1814. Article Crustaceology. The Edinburgh Encyclopaedia 7: 429-437.

Leis, J.M., 1986. Vertical and horizontal distribution of fish larvae near coral reefs at Lizard Island, Great Barrier Reef. Marine Biology 90: 505-516.

Mayer, P., 1882. Caprelliden. Fauna und Flora des Golfes von Neapel 6: 1-201.

Mayer, P., 1890. Die Caprelliden des Golfes von Neapel und der angrenzenden Meeres-Abschnitte. Fauna und Flora des Golfes von Neapel 17: 1-55.

Mayer, P., 1898. Metaprotella sandalensis n.sp. Zoological Results Based on Material from New Britain, New Guinea, Loyalty Islands and Elsewhere, Collected during the Years 1895, 1896 and 1897, by Arthur Willey, D.Sc. Lond., M.A. Cantab. Part I, 53-56.

Mayer, P., 1901. Description d'une nouvelle espèce de Crustacé Amphipode de la famille des Caprellidés (Caprella erethizon). Bulletin de la Societé Amis des Ciences Naturelles de Rouen: 239-245.

Mayer, P., 1903. Die Caprelliden der Siboga-Expedition. Siboga Expeditie 34: 1-160.

Mayer, P., 1912. Caprellidae. In Fauna Südwest-Australiens, ed. W. Michaelsen \& R. Hartmeyer, vol. 4(1): 1-14.

McCain, J.C., 1968. The Caprellidea (Crustacea: Amphipoda) of the western North Atlantic. Bulletin of the United States National Museum 278: 1-116.

McCain, J.C., \& J.E. Steinberg, 1970. Amphipoda-I, CaprellideaI. Crustaceorum Catalogus 2: 1-78.

McCune, B., \& M.J. Mefford, 1997. PC-ord. Multivariate analysis of Ecological Data. Gleneden Beach, USA: MJM Software Design, $47 \mathrm{pp}$.

Montagu, G., 1804. Description of several marine animals found on the south coast of Devonshire. Transactions of the Linnean Society of London 7: 61-85.

Müller, H.G., 1990. New species and records of coral reef inhabiting Caprellidea from Bora Bora and Moorea, Society Islands (Crustacea: Amphipoda). Revue suisse Zoologie 97(4): 827-842. 
Myers, A.A., \& J.K. Lowry, 2003. A phylogeny and a new classification of the Corophiidea Leach, 1814 (Amphipoda). Journal of Crustacean Biology 23(2): 443-485.

Nicolet, H., 1849. Crustáceos. In Historia física y política de Chile, ed. C. Gay. Zoología 3: 115-318.

Quitete, J.M.P.A., 1972. Hemiaegina costai, nova espécie de Caprellidae da costa brasileira (Crustacea: Amphipoda). Atas da Sociedade de Biologia Rio de Janeiro 15(3): 165-168.

Recher, H.F., \& W.F. Ponder, 1981. Lord Howe Island. Occasional Reports of the Australian Museum 1: 1-20

Sánchez-Moyano, J.E., J.L. Carballo \& F. Estacio, 1995. Pedoculina garciagomezi (Amphipoda: Caprellidea), new species from Bahía de Algeciras (Southern Spain). Crustaceana 68: 418-427.

Sánchez-Moyano, J.E., J.A. Jiménez-Martín \& J.C. GarcíaGómez, 1995. Caprella santosrosai n.sp. (Amphipoda: Caprellidea) from the Strait of Gibraltar (Southern Spain). Ophelia 43: 197-204.

Serejo, C.S., 1997. Hemiaegina costai Quitete, 1972, a synonym of Hemiaegina minuta Mayer, 1890 (Amphipoda, Caprellidae). Crustaceana 70(5): 630-632.

Slabber, M., 1769. Natuurkundige Verlustigingen, behelzende microscopise Waarneemingen va in -en uitlandse water- en land-Dieren. Te Haarlem: J. Bosh, 166 pp.

Sneath, P.H.A., \& R.R. Sokal, 1973. Numerical Taxonomy. The Principles and Practique of Numerical Classification. San Francisco: WH Freeman and Company, 573 pp.

Springthorpe, R.T., \& J.K. Lowry, 1994. Catalogue of crustacean type specimens in the Australian Museum: Malacostraca. Technical Reports of the Australian Museum 11: 1-134.

Stebbing, T.R.R., 1878. Notes on sessile-eyed crustaceans, with description of a new species. Annals and Magazine of Natural History 1: 31-37.
Stebbing, T.T.R., 1888. Report on the Amphipoda collected by H.M.S. Challenger during the years 1873-1876. Report on the Scientific Results of the Voyage of H.M.S. Challenger during the years 1873-1876, Zoology 29: xxiv + 1737 .

Stebbing, T.T.R., 1910. Scientific results of the trawling expedition of HMCS Thetis Crustacea, Part 5: Amphipoda. Memoirs of the Australian Museum 4(12): 567-658.

Sundara Raj, B., 1927. Suborder Caprellidea (Laemodipoda). The littoral fauna of Krusada Island in the Gulf of Manaar. The Bulletin of the Madras Government Museum, Natural History Section 1: 125-128.

Takeuchi, I., 1993. Is the Caprellidea a monophyletic group? Journal of Natural History 27: 947-964.

Takeuchi, I., S. Takahashi, S. Tanabe \& N. Miyazaki, 2001. Caprella watch; a new approach for monitoring butyltin residues in the ocean. Marine Environmental Research 52(2): 97-113.

Takeuchi, I., \& R. Hirano, 1995. Clinging behaviour of the epifaunal caprellids (Amphipoda) inhabiting the Sargassum zone on the Pacific coast of Japan, with its evolutionary implications. Journal of Crustacean Biology 15(3): 481-492.

Utinomi, H., 1947. Caprellidae of Japan and adjacent waters. Seibutu Supplement 1: 68-82.

Whitley, G.P., 1937. The Middleton and Elizabeth reefs, South Pacific Ocean. Australian Zoologist 8: 199-208.

Manuscript received 11 December 2002, revised 11 July 2005 and accepted 24 May 2006.

Associate Editor: Shane T. Ahyong.

Appendix. List of stations.

BK-113 Patch Reefs off Palfrey Island, Lizard Island, Queensland, rubble in depressions between coral heads, collected by hand on SCUBA, 8 m, B. Kensley, 10 Jan 1982.

BK-114 North Point, Lizard Island, Queensland, fine filamentous algae, collected by hand on SCUBA, 2 m, B. Kensley, 11 Jan 1982.

BK-126 Reef flat between Bird and South Island, Lizard Island, Queensland, fuzzy red algae, collected by hand on SCUBA, 3 m, B. Kensley, 16 Jan 1982

BK-127 Crest of Patch Reef in Lizard Island Lagoon, Lizard Island, Queensland, rubble with algal turf taken from the depressions on crest, collected by hand on SCUBA, 8 m, B. Kensley, 16 Jan 1982.

GBR 1 off Mangrove Beach, Lizard Island, Queensland, $14^{\circ} 40^{\prime} \mathrm{S}$ $145^{\circ} 28^{\prime} \mathrm{E}$, mixed algae from bommie, $2 \mathrm{~m}$, J.K. Lowry, 28 Sep 1978.

GBR 5 Lagoon, Lizard Island, Queensland, $14^{\circ} 41^{\prime} \mathrm{S} 145^{\circ} 28^{\prime} \mathrm{E}, 1.5$ m, C. Short \& P.C. Terrill, 30 Sep 1978.

GBR 6 off Mangrove Beach, Lizard Island, Queensland, 14²0'S 1452'ㄹ, sand, 1.5 m, C. Short \& A.R. Jones, 30 Sep 1978.

GBR 7 Between Mangrove Beach \& South Island, Lizard Island, Queensland, $14^{\circ} 40^{\prime} \mathrm{S} 145^{\circ} 28^{\prime} \mathrm{E}$, sand, $9 \mathrm{~m}$, J.K. Lowry \& P.C. Terrill, 30 Sep 1978.

GBR 10 off south end Casuarina Beach, Lizard Island, Queensland, $14^{\circ} 40^{\prime} \mathrm{S} 145^{\circ} 28^{\prime} \mathrm{E}$, beach sand, low water mark, J.K. Lowry, 4 Oct 1978

GBR 11 west end lagoon, Lizard Island, Queensland, $14^{\circ} 40^{\prime} \mathrm{S}$ $145^{\circ} 28^{\prime} \mathrm{E}$, algae Halimeda micronesica, Caulerpa racemosa, 3 m, J.K. Lowry, C. Short \& P.C. Terrill, 5 Oct 1978.

GBR 12 Lagoon, Lizard Island, Queensland, $14^{\circ} 40^{\prime} \mathrm{S} 145^{\circ} 28^{\prime} \mathrm{E}$, mixed algae from artificial reef cages, Lynbya sp., $4.5 \mathrm{~m}$, P.C. Terrill, 5 Oct 1978

GBR 14 Between Bird Islet \& Trawler Beach, Lizard Island, Queensland, $14^{\circ} 40^{\prime} \mathrm{S} 145^{\circ} 28^{\prime} \mathrm{E}$, sand, $15 \mathrm{~m}$, J.K. Lowry \& P.C. Terrill, 5 Oct 1978 .
GBR 15 Between Bird Islet \& South Island, Lizard Island, Queensland, $14^{\circ} 40^{\prime} \mathrm{S} 145^{\circ} 28^{\prime} \mathrm{E}$, coral rubble, $21 \mathrm{~m}$, A.R. Jones, 7 Oct 1978.

GBR 19 Between Bird Islet \& South Island, Lizard Island, Queensland, $14^{\circ} 40^{\prime} \mathrm{S} 145^{\circ} 28^{\prime} \mathrm{E}$, coral rubble, $6 \mathrm{~m}$, P.C. Terrill, 7 Oct 1978.

GBR 20 Between Bird Islet \& South Island, Lizard Island, Queensland, $14^{\circ} 40^{\prime} \mathrm{S} 145^{\circ} 28^{\prime} \mathrm{E}$, coral rubble, $6 \mathrm{~m}$, J.K. Lowry, 7 Oct 1978.

GBR 21 Between Bird Islet \& South Island, Lizard Island, Queensland, $14^{\circ} 40^{\prime} \mathrm{S} 145^{\circ} 28^{\prime} \mathrm{E}$, Halophila, Caulerpa, Halimeda, 25.5 m, J.K.Lowry, 7 Oct 1978.

GBR 25 off southern point Mermaid Cove, Lizard Island, Queensland, $14^{\circ} 40^{\prime} \mathrm{S} 145^{\circ} 28^{\prime} \mathrm{E}$, filamentous algae, sediment, $5 \mathrm{~m}$, C. Short \& P.C Terrill, 8 Oct 1978.

GBR 26 Mermaid Cove, Lizard Island, Queensland, $14^{\circ} 41^{\prime} \mathrm{S}$ $145^{\circ} 28^{\prime} \mathrm{E}$, sand between corals, $6 \mathrm{~m}, \mathrm{C}$. Short \& P.C. Terrill, 8 Oct 1978.

GBR 27 Between Bird Islet \& South Island, Lizard Island, Queensland, $14^{\circ} 40^{\prime} \mathrm{S} 145^{\circ} \mathrm{E}$, sediment at reef base with mixed algae, 25 m, J.K. Lowry, 9 Oct 1978

GBR 28 Between Bird Islet \& South Island, Lizard Island, Queensland, $14^{\circ} 40^{\prime} \mathrm{S} 145^{\circ} 28^{\prime} \mathrm{E}$, sediment at reef base with mixed algae 25 m, P.C. Terrill, 9 Oct 1978

GBR 29 Between Bird Islet \& South Island, Lizard Island, Queensland, $14^{\circ} 41^{\prime} \mathrm{S} 145^{\circ} 28^{\prime} \mathrm{E}$, sediment at reef base with mixed algae, 25 m, J.K. Lowry, 9 Oct 1978.

GBR 30 Between Bird Islet \& South Island, Lizard Island, Queensland, $14^{\circ} 40^{\prime} \mathrm{S} 145^{\circ} 28^{\prime} \mathrm{E}$, mixed algae, sediment from grassbeds, $25 \mathrm{~m}$, P.C. Terrill, 9 Oct 1978.

GBR 33 western end Lagoon, Lizard Island, Queensland, $14^{\circ} 40^{\prime} \mathrm{S}$ $145^{\circ} 28^{\prime} \mathrm{E}$, sand, $3 \mathrm{~m}$, P.C. Terrill, 15 Oct 1978.

GBR 43 Between Bird Islet \& Trawler Beach, Lizard Island, Queensland, $14^{\circ} 40^{\prime} \mathrm{S} 145^{\circ} 28^{\prime} \mathrm{E}$, sand, algae, $10 \mathrm{~m}$, P.C. Terrill, 15 Oct 1978. 
GBR 44 Off Chinamans Ridge, Lizard Island, Queensland, 140 $40^{\prime} \mathrm{S}$ 145 $28^{\prime} \mathrm{E}$, sand, mixed algae, 21 m, J.K. Lowry, 13 Oct 1978.

GBR 45 Off Chinamans Ridge, Lizard Island, Queensland, 14²0'S 145 $28^{\prime} \mathrm{E}$, sand, mixed algae, $21 \mathrm{~m}$, P.C. Terrill, 13 Oct 1978.

GBR 46 Off Chinamans Ridge, Lizard Island, Queensland, $14^{\circ} 40^{\prime} \mathrm{S}$ $145^{\circ} 28^{\prime} \mathrm{E}$, fine sand, $12 \mathrm{~m}$, J.K. Lowry, 13 Oct 1978.

GBR 48 Mermaid Cove, Lizard Island, Queensland, $14^{\circ} 40^{\prime} \mathrm{S}$ $145^{\circ} 28^{\prime} \mathrm{E}$, mixed algae, coral rubble, silt, $2 \mathrm{~m}$, J.K.Lowry, 14 Oct 1978.

GBR 49 Off North Point, Lizard Island, Queensland, $14^{\circ} 40^{\prime} \mathrm{S}$ 145 $28^{\prime} \mathrm{E}$, algae, coral rubble, 5 m, J.K.Lowry, 14 Oct 1978.

GBR 50 Off North Point, Lizard Island, Queensland, $14^{\circ} 40^{\prime} \mathrm{S}$ $145^{\circ} 28^{\prime} \mathrm{E}$, mixed algae, $5 \mathrm{~m}$, J.K.Lowry, 14 Oct 1978.

GBR 52 Off North Point, Lizard Island, Queensland, $14^{\circ} 40^{\prime} \mathrm{S}$ $145^{\circ} 28^{\prime} \mathrm{E}$, algae, Halimeda sp, 6 m, J.K.Lowry, 14 Oct 1978.

GBR $55200 \mathrm{~m}$ NW of Palfrey Island, Lizard Island, Queensland, $14^{\circ} 40^{\prime} \mathrm{S} 145^{\circ} 28^{\prime} \mathrm{E}$, sand beneath coral boulders, $3 \mathrm{~m}$, P.C. Terrill, 16 Oct 1978.

GBR $56200 \mathrm{~m}$ NW of Palfrey Island, Lizard Island, Queensland, $14^{\circ} 40^{\prime} \mathrm{S} 145^{\circ} 28^{\prime} \mathrm{E}$, sand $12 \mathrm{~m}, \mathrm{~J} . \mathrm{K}$. Lowry, 16 Oct 1978.

GBR $591.6 \mathrm{~km} \mathrm{SW}$ of Eagle Island, Lizard Island, Queensland, $14^{\circ} 40^{\prime} \mathrm{S} 145^{\circ} 28^{\prime} \mathrm{E}$, sediment from coral fans, coral ruble, 6 m, J.K. Lowry, 17 Oct 1978

GBR $631.6 \mathrm{~km} \mathrm{SW}$ of Eagle Island, Lizard Island, Queensland, $14^{\circ} 40^{\prime} \mathrm{S} 145^{\circ} 28^{\prime} \mathrm{E}$, sand, $12 \mathrm{~m}$, A.R. Jones, 17 Oct 1978.

GBR 68 Bommie W of harbour entrance, Heron Island, Queensland,

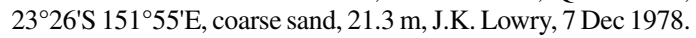

LHA 11 Between Comet Hole and Reef, Lord Howe Island, assorted red and brown algae with some coral, 2-3 m, J.K. Lowry, 10 May 1977.

LHA 17 Reef front S of North Passage, straight out from Signal Point, between rubble spurs, Lord Howe Island, coralline, $3 \mathrm{~m}$, J.K. Lowry, 11 May 1977.

LHA 48 Old Gulch, Lord Howe Island, lower sides of lower littoral boulders, among algae, G.D. Fenwick, 17 May 1977.

LHA 49 Old Gulch, Lord Howe Island, among algae on mid littoral boulders, J.K. Lowry, 17 May 1977.

LHA 51 Old Gulch, Lord Howe Island, among red algae (Galaxaria sp.) on rock, 7 m, J.K.Lowry, 17 May 1977.

St 1 Shallow reef front, Middleton Reef, $29^{\circ} 27.2^{\prime} \mathrm{S} 159^{\circ} 06.8^{\prime} \mathrm{E}$, sand and rubble, $10 \mathrm{~m}, 4 \mathrm{Dec} 1987$.

St 7 Large alcove near lagoon entrance, Sound dive site, Middleton Reef, $29^{\circ} 27.7^{\prime} \mathrm{S} 159^{\circ} 05.4^{\prime} \mathrm{E}, 6 \mathrm{~m}$, P. Hutchings \& I.Loch, 5 Dec 1987.

St 8.1 Shelf Runil Reef, Middleton Reef, 29 ${ }^{\circ} 27.4^{\prime}$ S $159^{\circ} 03.7^{\prime} E$, dead corals, 9-12 m, 5 Dec 1987.

St $10 \quad$ NE to E outer slope, Middleton Reef, $29^{\circ} 26.1^{\prime} \mathrm{S} 159^{\circ} 08.2^{\prime} \mathrm{E}$, $10 \mathrm{~m}, 6$ Dec 1987.

St 12 Patch Reef, Middleton Reef, 29²7.6'S 159 06.7'E, 6 Dec 1987.

St 14 reef near "Fuku Maru" wreck, Middleton Reef, 29²8.8'S $159^{\circ} 07.5^{\prime} \mathrm{E}, 7$ Dec 1987.

St 20 Slope off Fuku Maru, Middleton Reef, $29^{\circ} 29.1^{\prime} \mathrm{S} 159^{\circ} 08.1^{\prime} \mathrm{E}$, rubble, 15-20 m, 7 Dec 1987.

St 21 Southern slope, between "Runic" and "Fuku Maru", Middleton Reef, $29^{\circ} 29.5^{\prime} \mathrm{S} 159^{\circ} 06.2^{\prime} \mathrm{E}, 15-17 \mathrm{~m}, 8$ Dec 1987.

St 23 Outer slope, W of Runil, Middleton Reef, $29^{\circ} 28^{\prime} \mathrm{S}$ 159 03.3'E, 9 Dec 1987.

St 30 Outer slope, W of "Yoshin Maru Iwaki", Elizabeth Reef, $29^{\circ} 57.2^{\prime} \mathrm{S} 159^{\circ} 01.2^{\prime} \mathrm{E}$, coral rubble, 8-24 m, J.K. Lowry \& R.T. Springthorpe, 12 Dec 1987.

St 32 Reef front, Elizabeth Reef, $29^{\circ} 54.8^{\prime} \mathrm{S} 159^{\circ} 02.8^{\prime} \mathrm{E}$, algae, 10 Dec 1987.

St 34 SW Outer slope, Elizabeth Reef, $29^{\circ} 57.7^{\prime} \mathrm{S} 159^{\circ} 02.8^{\prime} \mathrm{E}$, algae, 11 Dec 1987.

St 36 Off Flamingo Bay, outer slope, southern face, Elizabeth Reef, 29 57.8'S 159 04.7'E, 5 m, P. Hutchings, 11 Dec 1987.

St 37 Outer slope SE face, Elizabeth Reef, $29^{\circ} 58^{\prime} \mathrm{S} 159^{\circ} 05.1^{\prime} \mathrm{E}$, 11 Dec 1987

St 38 Deep lagoon bommie, Elizabeth Reef, $29^{\circ} 56.2^{\prime} \mathrm{S} 159^{\circ} 02.4^{\prime} \mathrm{E}$, 10 m, ?fine sediment, 12 Dec 1987.

St 43 Reef flat near Yoshiu Maru Iwaki, Elizabeth Reef, 29 $57.2^{\prime}$ S 15901.2'E, J.K Lowry \& R.T. Springthorpe, 14 Dec 1987.

St 45 Outer slope near Famingo Bay, on wreck, Elizabeth Reef, $29^{\circ} 56.5^{\prime} \mathrm{S} 159^{\circ} 01.8^{\prime} \mathrm{E}, 7-15 \mathrm{~m}, 14 \mathrm{Dec} 1987$

QLD 639 Reef front crest, Great Detached Reef, Queensland, $11^{\circ} 42.17^{\prime} \mathrm{S} 144^{\circ} 1.61^{\prime} \mathrm{E}$, Halimeda, SCUBA, $9 \mathrm{~m}$, S. Keable, 12 Jan 1993.
QLD 646 Shadwell Reef, Queensland, $11^{\circ} 27.66^{\prime} \mathrm{S} 143^{\circ} 46.63^{\prime} \mathrm{E}$, water column, 0 m, H. Larson, J. Leis, McGrouther, 12 Jan 1993.

QLD 650 GBRMPA Reef 11-102, Queensland, $11^{\circ} 27.56$ 'S $143^{\circ} 58$. $12^{\prime} \mathrm{E}$, living short low clumps of multibranched hard coral, 9 m, S. Keable, 13 Jan 1993.

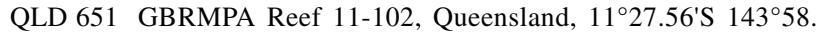
12'E, coral rubble, 9 m, S. Keable, 13 Jan 1993.

QLD 658 Back reef slope,GBRMPA Reef 11-131, Queensland, $11^{\circ} 26.96^{\prime} \mathrm{S} 144^{\circ} 4.06 " \mathrm{E}$, Halimeda, SCUBA, 9 m, S. Keable, 14 Jan 1993.

QLD 659 Back reef flat, GBRMPA Reef 11-131, Queensland, $11^{\circ} 26.966^{\prime} \mathrm{S} 144^{\circ} 4.06 \mathrm{E}$, Halimeda, SCUBA, 3 m, S. Keable, 14 Jan 1993.

QLD 660 Back reef flat, GBRMPA Reef 11-131, Queensland, $11^{\circ} 26.96^{\prime} \mathrm{S} 144^{\circ} 4.06 \mathrm{E}$, rubble, SCUBA, $3 \mathrm{~m}$, S. Keable, 14 Jan 1993.

QLD 664 SW end of reef in gully of back reef slope, GBRMPA Reef 11-418, Queensland, $10^{\circ} 59.98^{\prime} \mathrm{S} 144^{\circ} 1.22^{\prime} \mathrm{E}$, mixed sponges, SCUBA, 3 m, S. Keable, 15 Jan 1993.

QLD 667 SW end of reef in gully of back reef slope, GBRMPA Reef 11-418, Queensland, $10^{\circ} 59.98^{\prime} \mathrm{S} 144^{\circ} 1.22^{\prime} \mathrm{E}$, Halimeda and Caulerpa, SCUBA, 6 m, S. Keable, 15 Jan 1993.

QLD 668 SW end of reef in gully of back reef slope, GBRMPA Reef 11-418, Queensland, $10^{\circ} 59.98^{\prime} \mathrm{S} 144^{\circ} 1.22^{\prime} \mathrm{E}$, coral rubble, SCUBA, 6 m, S. Keable, 15 Jan 1993.

QLD 674 Inside Outer Barrier, Queensland, $10^{\circ} 56.90$ 'S $144^{\circ} 0.51^{\prime} \mathrm{E}$, coral rubble, SCUBA, 20 m, S. Keable, 16 Jan 1993.

QLD 675 Small bommie NW of GBRMPA Reef 10-403, Queensland, $10^{\circ} 48.61$ 'S $143^{\circ} 59.36^{\prime} \mathrm{E}$, rubble, SCUBA, $16 \mathrm{~m}, \mathrm{C}$. Kirby, 16 Jan 1993.

QLD 680 Inside Outer Barrier, Queensland, $10^{\circ} 34.48^{\prime} \mathrm{S} 143^{\circ} 55.28^{\prime} \mathrm{E}$, purple sponge, SCUBA, $15 \mathrm{~m}$, S. Keable, 16 Jan 1993.

QLD 683 Inside Outer Barrier, Queensland, 10³4.48'S 143ํ⒌28'E, sediment and loose rubble, SCUBA, 15 m, S. Keable, 16 Jan 1993.

QLD 686 Ashmore Reef, Queensland, 10²6.66'S 144²6.82'E, fine sediment, SCUBA, 15 m, S. Keable, 17 Jan 1993.

QLD 696 Outer reef slope, sheer drop off, Ashmore Reef, Queensland, $10^{\circ} 26.27^{\prime} \mathrm{S} 144^{\circ} 25.78^{\prime} \mathrm{E}$, Halimeda, SCUBA, $10 \mathrm{~m}$, S. Keable, 18 Jan 1993.

QLD 697 Outer reef face, sheer drop off, Ashmore Reef, Queensland, $10^{\circ} 26.27^{\prime} \mathrm{S} 144^{\circ} 25.78^{\prime} \mathrm{E}$, invertebrates, SCUBA, $30 \mathrm{~m}, \mathrm{~S}$. Keable, 18 Jan 1993.

QLD 703 Outer reef slope, sheer drop off, Ashmore Reef, Queensland, $10^{\circ} 26.27^{\prime} \mathrm{S} 144^{\circ} 25.78^{\prime} \mathrm{E}$, rubble, SCUBA, $30 \mathrm{~m}$, S. Keable, 19 Jan 1993.

QLD 704 Outer reef slope, sheer drop off, Ashmore Reef, Queensland, $10^{\circ} 26.27$ 'S $144^{\circ} 25.78^{\prime} \mathrm{E}$, red calcareous cylindrical algae, SCUBA, 25 m, S. Keable, 19 Jan 1993.

QLD 705 Outer reef slope, sheer drop off, Ashmore Reef, Queensland, $10^{\circ} 26.27^{\prime} \mathrm{S} 144^{\circ} 25.78^{\prime} \mathrm{E}$, sediment, algae and rubble, SCUBA, 12 m, S. Keable, 19 Jan, 1993.

QLD 721 Outer reef slope, sheer walls and caves, Ashmore Reef, Queensland, $10^{\circ} 13.16^{\prime} \mathrm{S} 144^{\circ} 24.89^{\prime} \mathrm{E}$, tunicates, SCUBA, 31 m, S. Keable, 22 Jan 1993.

QLD 722 Outer reef slope, Ashmore Reef, Queensland, $10^{\circ} 13.16$ 'S $144^{\circ} 24.89^{\prime} \mathrm{E}$, sponges, SCUBA, $25 \mathrm{~m}$, S. Keable, 22 Jan 1993.

QLD 723 Outer reef slope, sheer walls and caves, Ashmore Reef, Queensland, $10^{\circ} 13.16^{\prime} \mathrm{S} 144^{\circ} 24.89^{\prime} \mathrm{E}$, rubble, SCUBA, 12 $\mathrm{m}, \mathrm{S}$. Keable, 22 Jan, 1993.

QLD 724 Outer reef slope, Ashmore Reef, Queensland, $10^{\circ} 13.16^{\prime} \mathrm{S}$ $144^{\circ} 24.89^{\prime} \mathrm{E}$, consolidated reef with algal turf, SCUBA, 3 m, S. Keable, 22 Jan 1993.

QLD 733 Outer slope, E edge Ashmore Reef, $10^{\circ} 9.16^{\prime} \mathrm{S} 144^{\circ} 34.72^{\prime} \mathrm{E}$, rubble, SCUBA, 30 m, S. Keable, 24 Jan 1993.

QLD 734 Outer slope of eastern edge, Ashmore Reef, $10^{\circ} 9.16^{\prime} \mathrm{S}$ $144^{\circ} 34.72^{\prime} \mathrm{E}$, calcareous red tubular algae, SCUBA, $30 \mathrm{~m}$, S. Keable, 24 Jan 1993.

QLD 735 Outer reef slope, E edge Ashmore Reef, 10 ${ }^{\circ} 9.16^{\prime} \mathrm{S}$ $144^{\circ} 34.72^{\prime} \mathrm{E}$, living coral, SCUBA, $20 \mathrm{~m}$, S. Keable, 24 Jan 1993.

QLD 739 Outer reef slope, E edge Ashmore Reef, $10^{\circ} 9.52^{\prime} \mathrm{S}$ 1443․ ${ }^{\circ}$ 'E, rubble, SCUBA, 20 m, S. Keable, 25 Jan 1993.

QLD 759 Gutter in reef flat, Boot Reef, Coral Sea, Queensland, $10^{\circ} 2.72^{\prime} \mathrm{S} 144^{\circ} 41.93^{\prime} \mathrm{E}$, Halimeda, SCUBA, $4 \mathrm{~m}, \mathrm{~S}$. Keable, 27 Jan 1993. 
QLD 760 Reef flat, Boot Reef, Coral Sea, Queensland, 10².72'S 14441.93'E, rubble, SCUBA, 4 m, S. Keable, 27 Jan 1993.

QLD 777 Reef slope, Portlock Reef, Coral Sea, Queensland, 9³8.58'S 144²9.67'E, SCUBA, 30 m, S. Keable, 29 Jan 1993.

QLD 856 Boat Rock, North Stradbroke Island, Queensland, 27²5.21'S $153^{\circ} 33.28^{\prime} \mathrm{E}$, olive green massive sponge (Psammocinia), collected by hand on SCUBA, $22 \mathrm{~m}, 21.8^{\circ} \mathrm{C}$, G.D.F. Wilson, 3 Jun 1993.

QLD 921 Sabina Point, Shoalwater Bay, Queensland, 22 ${ }^{\circ} 23.73^{\prime} \mathrm{S}$ $150^{\circ} 18.15^{\prime} \mathrm{E}$, sand, silt and algae in tide pools at low tide, collected with 100 micron hand net, $1 \mathrm{~m}, 24.0^{\circ} \mathrm{C}$, G.D.F. Wilson, 15 Sep 1993.

QLD 949 SW end of Dome Island, Hervey Islands, Queensland, $22^{\circ} 24.78^{\prime} \mathrm{S} 150^{\circ} 44.65^{\prime} \mathrm{E}$, algae covered cobbles, collected by airlift, $4 \mathrm{~m}, 22.6^{\circ} \mathrm{C}$, G.D.F. Wilson, 19 Sep 1993.

QLD 954 SW end of Dome Island, Hervey Islands, Queensland, $22^{\circ} 24.78$ 'S $150^{\circ} 44.65^{\prime} \mathrm{E}$, Sargassum, collected by hand on SCUBA, $6 \mathrm{~m}, 22.6^{\circ} \mathrm{C}$, A. Murray, 19 Sep 1993.

QLD 955 SW end of Dome Island, Hervey Islands, Queensland, $22^{\circ} 24.78^{\prime} \mathrm{S} 150^{\circ} 44.65^{\prime} \mathrm{E}$, scrapings from rock, Halimeda, Dictyota, Lobophora and corallines, collected by hand on SCUBA, $6 \mathrm{~m}, 22.6^{\circ} \mathrm{C}$, A. Murray, 19 Sep 1993.

QLD 957 SE Quoin Island, Port Clinton, Queensland, $22^{\circ} 34.02^{\prime} \mathrm{S}$ $150^{\circ} 47.89^{\prime} \mathrm{E}$, Caulerpa, Codium and sponges of rocky ridge, collected by hand on SCUBA, $10 \mathrm{~m}, 22.4^{\circ} \mathrm{C}$, A. Murray, 20 Sep 1993.

QLD 968 Island off S end of Freshwater Bay, Queensland, 22 ${ }^{\circ} 38.84^{\prime} \mathrm{S}$ $150^{\circ} 47.52^{\prime} \mathrm{E}$, Sargassum, collected by hand on snorkel, 2 m, 23.0 ${ }^{\circ}$, G.D.F. Wilson, 21 Sep 1993.
QLD 969 Island off S end of Freshwater Bay, Queensland, 22³8.84'S $150^{\circ} 47.52^{\prime} \mathrm{E}$, mixed benthic habitat, collected by hand on snorkel, $2 \mathrm{~m}, 23.0^{\circ} \mathrm{C}$, A. Murray, $21 \mathrm{Sep} 1993$.

QLD 972 Island off S end of Freshwater Bay, Queensland, 22 $38.84^{\prime} \mathrm{S}$ $150^{\circ} 47.52^{\prime} \mathrm{E}$, algae ?Dictyota, collected by hand on snorkel, $2 \mathrm{~m}, 23.0^{\circ} \mathrm{C}$, G.D.F. Wilson, 21 Sep 1993.

QLD 979 Island off $\mathrm{S}$ end of Freshwater Bay, Queensland, $22^{\circ} 38.84^{\prime} \mathrm{S}$ $150^{\circ} 47.52^{\prime} \mathrm{E}$, from underside of boulders, collected by airlift on SCUBA, $3 \mathrm{~m}, 22.4^{\circ} \mathrm{C}$, K.B. Attwood, 22 Sep 1993.

QLD 980 Island off $\mathrm{S}$ end of Freshwater Bay, Queensland, 22 38.84 'S $150^{\circ} 47.52^{\prime} \mathrm{E}$, sponge and ascidian from underneath rock, collected by hand on SCUBA, $3 \mathrm{~m}, 22.4^{\circ} \mathrm{C}$, G.D.F. Wilson, 22 Sep 1993.

QLD 983 Island off $\mathrm{S}$ end of Freshwater Bay, Queensland, $22^{\circ} 38.84^{\prime} \mathrm{S}$ $150^{\circ} 47.52^{\prime} \mathrm{E}$, eunicid tubes and ascidians under rock ledge, collected by hand on SCUBA, $3 \mathrm{~m}, 22.4^{\circ} \mathrm{C}$, A. Murray, 22 Sep 1993.

QLD 985 Island off southern end of Freshwater Bay, Queensland, $22^{\circ} 38.84^{\prime} \mathrm{S} 150^{\circ} 47.52^{\prime} \mathrm{E}$, piece of wood, collected by hand on SCUBA, $3 \mathrm{~m}, 22.4^{\circ} \mathrm{C}$, G.D.F. Wilson, 22 Sep 1993.

QLD 986 Island off $\mathrm{S}$ end of Freshwater Bay, Queensland, $22^{\circ} 38.84$ 'S $150^{\circ} 47.52^{\prime} \mathrm{E}$, from worm tubes from underside of ledge, collected by hand on SCUBA, $4 \mathrm{~m}, 22.4^{\circ} \mathrm{C}$, A. Murray, 22 Sep 1993

QLD 990 Island off S end of Freshwater Bay, Queensland, 22 38.84 'S $150^{\circ} 47.52^{\prime} \mathrm{E}$, onophid tubes and rubble from bottom, collected by hand on SCUBA, $3 \mathrm{~m}, 22.4^{\circ} \mathrm{C}$, A. Murray, 22 Sep 1993.

\title{
Lizard Island (sampling targeted on the Caprellidae).
}

\author{
All samples are preserved in 95\% ethanol:
}

QLD $1464 \mathrm{~W}$ side of Blue Lagoon between Palfrey Island and Lizard Island, Queensland, broken Acropora heavily encrusted with brown/green filamentous algae, collected by hand on SCUBA, 2-3 m, J.M. Guerra-García \& S.J. Keable, 7 Oct 2001.

QLD $1465 \mathrm{~W}$ side of Blue Lagoon between Palfrey Island and Lizard Island, Queensland, Turbinaria ornata, collected by hand on SCUBA, 2-3 m, J.M. Guerra-García \& S.J. Keable, 7 Oct 2001.

QLD $1468 \mathrm{~W}$ side of Blue Lagoon between Palfrey Island and Lizard Island, Queensland, colony of small brown tunicate cf. Aplidium sp., collected by hand on SCUBA, 2-3 m, J.M. Guerra-García \& S.J. Keable, 7 Oct 2001.

QLD $1469 \mathrm{~W}$ side of Blue Lagoon between Palfrey Island and Lizard Island, Queensland, coral rubble, collected by hand on SCUBA, 2-3 m, J.M. Guerra-García \& S.J. Keable, 7 Oct 2001.

QLD 1470 Blue Lagoon, Lizard Island, Queensland, hydroid Gymnangium sp. on hard coral, collected by hand on SCUBA, $9 \mathrm{~m}$, Soren Sehubert, Oct 2001.

QLD 1472 Coconut Beach, Lizard Island, Queensland, hydroid Aglaophenia cupressina, collected by hand on SCUBA, 34 m, J.M. Guerra-García \& S.J. Keable, 8 Oct 2001.

QLD 1473 Coconut Beach, Lizard Island, Queensland, dead Junceella (sea whip) heavily encrusted with various epiphytes, collected by hand on SCUBA, 12 m, J.M. Guerra-García \& S.J. Keable, 8 Oct 2001.

QLD 1474 Coconut Beach, Lizard Island, Queensland, hydroid Macrorhynchia philippina, collected by hand on SCUBA, 4 m, J.M. Guerra-García \& S.J. Keable, 8 Oct 2001.

QLD 1475 Coconut Beach, Lizard Island, Queensland, dead thick branching hard coral encrusted with calcareous red algae and filamentous algal turf, collected by hand on SCUBA, 8 m, J.M. Guerra-García \& S.J. Keable, 8 Oct 2001.

QLD 1476 Coconut Beach, Lizard Island, Queensland, fine live hard coral encrusted with calcareous red algae and filamentous red/green/brown algal turf, collected by hand on SCUBA, 6 m, J.M. Guerra-García \& S.J. Keable, 8 Oct 2001

QLD 1477 Coconut Beach, Lizard Island, Queensland, coral rubble, branching pieces and flat piece with small holes, collected by hand on SCUBA, 10-13 m, J.M. Guerra-García \& S.J. Keable, 8 Oct 2001.
QLD 1478 Coconut Beach, Lizard Island, Queensland, coarse shelly sediment, collected by hand on SCUBA, 12 m, J.M. GuerraGarcía \& S.J. Keable, 8 Oct 2001.

QLD 1482 Crystal Beach, Lizard Island, Queensland, low white encrusting sponge cf. Dysidea sp. from underside of cave roof, collected by hand on SCUBA, 7 m, J.M. Guerra-García \& S.J. Keable, 9 Oct 2001.

QLD 1483 Crystal Beach, Lizard Island, Queensland, thick branching coral rubble encrusted with red algal turf and black sponge half buried in sediment, collected by hand on SCUBA, $5 \mathrm{~m}$, J.M. Guerra-García \& S.J. Keable, 9 Oct 2001.

QLD 1484 Crystal Beach, Lizard Island, Queensland, hydroid Macrorhynchia philippina, collected by hand on SCUBA, 3 m, J.M. Guerra-García \& S.J. Keable, 9 Oct 2001.

QLD 1485 Crystal Beach, Lizard Island, Queensland, thin branching living coral heavily encrusted with brown/green algal turf and red calcareous algae, collected by hand on SCUBA, 4 m, J.M. Guerra-García \& S.J. Keable, 9 Oct 2001.

QLD 1486 Crystal Beach, Lizard Island, Queensland, coarse sediment composed largely of spiny foraminifera with some shell, collected by hand on SCUBA, 9-9.4 m, J.M. Guerra-García \& S.J. Keable, 9 Oct 2001.

QLD 1487 Crystal Beach, Lizard Island, Queensland, coarse sediment composed largely of spiny foraminifera with some shell and small pieces of coral rubble, collected by hand on SCUBA, 4-5 m, J.M. Guerra-García \& S.J. Keable, 9 Oct 2001.

QLD 1488 Just N of Turtle Beach, Lizard Island, Queensland, branching coral rubble heavily encrusted with calcareous red algae and algal turf, collected by hand on SCUBA, 6 m, J.M. GuerraGarcía \& S.J. Keable, 10 Oct 2001.

QLD 1503 Just N of Turtle Beach, Lizard Island, Queensland, clump of silty algae cf. Halymenia, collected by hand on SCUBA, 14 m, J.M. Guerra-García \& S.J. Keable, 10 Oct 2001.

QLD 1505 Just N of Turtle Beach, Lizard Island, Queensland, hydroid Macrorhynchia philippina, collected by hand on SCUBA, 14 m, J.M. Guerra-García \& S.J. Keable, 10 Oct 2001.

QLD 1507 Just N of Turtle Beach, Lizard Island, Queensland, erect brown sponge cf. Pericharax heteroraphis, collected by hand on SCUBA, 14 m, J.M. Guerra-García \& S.J. Keable, 10 Oct 2001. 
QLD 1509 Just N of Turtle Beach, Lizard Island, Queensland, hydroid Gymnangium sp. collected by hand on SCUBA, 14 m, J.M. Guerra-García \& S.J. Keable, 10 Oct 2001.

QLD 1511 Just N of Turtle Beach, Lizard Island, Queensland, sediment (about $40 \%<0.5 \mathrm{~mm}$ remaining $60 \%$ shelly and coarse sand), collected by hand on SCUBA, 2-3 m, J.M. Guerra-García \& S.J. Keable, 10 Oct 2001.

QLD 1514 Watsons Bay, Lizard Island, Queensland, sediment (c. 65\% $<0.5 \mathrm{~mm}$, remaining c. $35 \%$ coarse $(5 \mathrm{~mm})$ shell, Halimeda flakes and forams cf. Marginopora vertebralis), collected by hand on SCUBA, 18 m, J.M. Guerra-García \& S.J. Keable, 11 Oct 2001

QLD 1515 Watsons Bay, Lizard Island, Queensland, petrified branching stick covered in fine filamentous red algae, calcareous red algae and small brown alga cf. Zonaria, collected by hand on SCUBA, 18 m, J.M. Guerra-García \& S.J. Keable, 11 Oct 2001.

QLD 1516 Watsons Bay, Lizard Island, Queensland, Halimeda cylindracea, collected by hand on SCUBA, $18 \mathrm{~m}$, J.M. Guerra-García \& S.J. Keable, 11 Oct 2001.

QLD 1517 Watsons Bay, Lizard Island, Queensland, orange convoluted sponge cf. Clathria with some small algae Udotea, collected by hand on SCUBA, 18 m, J.M. Guerra-García \& S.J. Keable, 11 Oct 2001

QLD 1519 Watsons Bay, Lizard Island, Queensland, mixed sample of Caulerpa taxifolia some Halimeda cf. macroloba some Udotea and some flocculent material, collected by hand on SCUBA, 18 m, J.M. Guerra-García \& S.J. Keable, 11 Oct 2001.

QLD 1520 Watsons Bay, Lizard Island, Queensland, Caulerpa taxifolia, collected by hand on SCUBA, 18 m, J.M. Guerra-García \& S.J. Keable, 11 Oct 2001.

QLD 1522 Watsons Bay, Lizard Island, Queensland, alga cf. Gracilaria on dead Halimeda cylindracea with sediment (fine sand and shell), collected by hand on SCUBA, 18 m, J.M. GuerraGarcía \& S.J. Keable, 11 Oct 2001.

QLD 1523 Just N of Chinaman's Ridge, Lizard Island, Queensland, sediment (fine sand and shell) next to reef, collected by hand on snorkel, 4 m, J.M. Guerra-García \& S.J. Keable, 11 Oct 2001.

QLD 1524 Chinamans Ridge, Lizard Island, Queensland, Padina cf. gymnospora from reef, collected by hand on snorkel, $2 \mathrm{~m}$, J.M. Guerra-García \& S.J. Keable, 11 Oct 2001.

QLD 1525 NW edge of Palfrey Island, Lizard Island, Queensland, hydroid cf. Macrorhynchia philippina, collected by hand on SCUBA, 6 m, J.M. Guerra-García \& S.J. Keable, 12 Oct 2001.

QLD 1526 NW edge of Palfrey Island, Lizard Island, Queensland, Halimeda micronesica and $H$. macroloba, collected by hand on SCUBA, 3 m, J.M. Guerra-García \& S.J. Keable, 12 Oct 2001.

QLD 1527 NW edge of Palfrey Island, Lizard Island, Queensland, hydroid Gymnangium sp., collected by hand on SCUBA, 6 m, J.M. Guerra-García \& S.J. Keable, 12 Oct 2001.

QLD 1528 NW edge of Palfrey Island, Lizard Island, Queensland, dead Junceella heavily encrusted with red algal turf and calcareous red algae, collected by hand on SCUBA, 12 m, J.M. GuerraGarcía \& S.J. Keable, 12 Oct 2001.

QLD $1529 \mathrm{NW}$ edge of Palfrey Island, Lizard Island, Queensland, Padina sp., collected by hand on SCUBA, 3-12 m, J.M. Guerra-García \& S.J. Keable, 12 Oct 2001.

QLD 1531 NW edge of Palfrey Island, Lizard Island, Queensland, dead gorgonian with epiphytes, collected by hand on SCUBA, 12 m, J.M. Guerra-García \& S.J. Keable, 12 Oct 2001.

QLD 1532 NW edge of Palfrey Island, Lizard Island, Queensland, sediment (coarse-medium sand with c. 35\% medium shell), collected by hand on SCUBA, 12 m, J.M. Guerra-García \& S.J. Keable, 12 Oct 2001.

QLD 1533 N end of Mermaid Beach, Lizard Island, Queensland, Padina sp., collected by hand on snorkel, 4 m, J.M. Guerra-García \& S.J. Keable, 12 Oct 2001.

QLD 1536 Blue Lagoon between Bird Islet and South Island, Lizard Island, Queensland, mixed encrusted coral rubble, collected by hand on SCUBA, 2 m, J.M. Guerra-García \& S.J. Keable, 13 Oct 2001.

QLD 1537 Blue Lagoon between Bird Islet and South Island, Lizard Island, Queensland, fine sediment $(100 \%<0.5 \mathrm{~mm})$, collected by hand on SCUBA, 10 m, J.M. Guerra-García \& S.J. Keable, 13 Oct 2001.
QLD 1538 Blue Lagoon between Bird Islet and South Island, Lizard Island, Queensland, sediment (medium grained sand), collected by hand on SCUBA, 6 m, J.M. Guerra-García \& S.J. Keable, 13 Oct 2001.

QLD 1541 Reef slope on S side of South Island, Lizard Island, Queensland, gorgonian cf. Paracis sp., collected by hand on SCUBA, $20 \mathrm{~m}$, J.M. Guerra-García \& S.J. Keable, 14 Oct 2001.

QLD 1543 Reef slope on S side of South Island, Lizard Island, Queensland, unidentified fine delicate hydroid, collected by hand on SCUBA, 25 m, J.M. Guerra-García \& S.J. Keable, 14 Oct 2001.

QLD 1544 Reef slope on S side of South Island, Lizard Island, Queensland, gorgonian cf. Menella sp., collected by hand on SCUBA, 25 m, J.M. Guerra-García \& S.J. Keable, 14 Oct 2001.

QLD 1545Reef slope on S side of South Island, Lizard Island, Queensland, gorgonian cf. Mopsella sp., collected by hand on SCUBA, 20 m, J.M. Guerra-García \& S.J. Keable, 14 Oct 2001.

QLD 1546 Reef slope on S side of South Island, Lizard Island, Queensland, hydroid Aglaophenia delicatula, collected by hand on SCUBA, 20 m, J.M. Guerra-García \& S.J. Keable, 14 Oct 2001.

QLD 1547 Reef slope on S side of South Island, Lizard Island, Queensland, hydroid Macrorhynchia philippina, collected by hand on SCUBA, 10-20 m, J.M. Guerra-García \& S.J. Keable, 14 Oct 2001.

QLD 1549 Reef slope on S side of South Island, Lizard Island, Queensland, coarse coral sediment with some small gravel and rubble, collected by hand on SCUBA, $20 \mathrm{~m}$, J.M. GuerraGarcía \& S.J. Keable, 14 Oct 2001.

QLD 1550Reef slope on S side of South Island, Lizard Island, Queensland, purple tube sponge cf. Kallypilidion sp., collected by hand on SCUBA, 20 m, J.M. Guerra-García \& S.J. Keable, 14 Oct 2001.

QLD 1553 North Point, Lizard Island, Queensland, hydroid cf. Aglaophenia sp. (not A. cupressina), collected by hand on SCUBA, 7 m, J.M. Guerra-García \& S.J. Keable, 14 Oct 2001.

QLD 1554 North Point, Lizard Island, Queensland, mixed hydroids (Aglaophenia, Gymnangium and Macrorhynchia) from walls and caves of canyon with strong current, collected by hand on SCUBA, 5-6 m, J.M. Guerra-García \& S.J. Keable, 14 Oct 2001.

QLD 1557 Outer reef slope midway between Bird Islet and South Island, Lizard Island, Queensland, caprellids from small orange gorgonian, collected by hand on SCUBA, 6 m, J.M. GuerraGarcía \& S.J. Keable, 15 Oct 2001.

QLD 1559 Outer reef slope midway between Bird Islet and South Island, Lizard Island, Queensland, tunicates cf. Polycarpa pigmentata encrusted with algal turf and hydroids from sediment slope, collected by hand on SCUBA, $20 \mathrm{~m}$, J.M. Guerra-García \& S.J. Keable, 15 Oct 2001.

QLD 1560 Outer reef slope midway between Bird Islet and South Island, Lizard Island, Queensland, hydroid Salacia n.sp. from sediment slope, collected by hand on SCUBA, 25 m, J.M. Guerra-García \& S.J. Keable, 15 Oct 2001.

QLD 1561 Outer reef slope midway between Bird Islet and South Island, Lizard Island, Queensland, hydroid Macrorhynchia phoenicia from sediment slope, collected by hand on SCUBA, 10-15 m, J.M. Guerra-García \& S.J. Keable, 15 Oct 2001.

QLD 1562 Outer reef slope midway between Bird Islet and South Island, Lizard Island, Queensland, hydroid Macrorhynchia philippina from sediment slope, collected by hand on SCUBA, c. $10 \mathrm{~m}$, J.M. Guerra-García \& S.J. Keable, 15 Oct 2001.

QLD 1563 Outer reef slope midway between Bird Islet and South Island, Lizard Island, Queensland, coarse shelly sediment from slope with some foraminifera (cf. Marginopora) and Halophila ovalis, collected by hand on SCUBA, 15-20 m, J.M. GuerraGarcía \& S.J. Keable, 15 Oct 2001.

QLD 1564 Reef slope S of "Washing Machine", NE side of Lizard Island, Queensland, mixed hydroids ( $90 \%$ brown unidentified species, remainder Macrorhynchia philippina), collected by hand on SCUBA, 5 m, J.M. Guerra-García \& S.J. Keable, 16 Oct 2001

QLD 1565 Reef slope S of "Washing Machine", NE side of Lizard Island, Queensland, caprellids from brown sponge cf. Clathria reinwardti, collected by hand on SCUBA, $18 \mathrm{~m}$, J.M. Guerra-García \& S.J. Keable, 16 Oct 2001. 
QLD 1567 Reef slope S of "Washing Machine", NE side of Lizard Island, Queensland, hydroid cf. Solanderia sp. from cave, collected by hand on SCUBA, 6 m, J.M. Guerra-García \& S.J. Keable, 16 Oct 2001.

QLD 1568 Reef slope S of "Washing Machine", NE side of Lizard Island, Queensland, Halimeda macroloba, collected by hand on SCUBA, 6 m, J.M. Guerra-García \& S.J. Keable, 16 Oct 2001.

QLD 1569 Reef slope S of "Washing Machine", NE side of Lizard Island, Queensland, sediment with Halimeda cylindracea, some Udotea and Caulerpa sp., collected by hand on SCUBA, $5 \mathrm{~m}$, J.M. Guerra-García \& S.J. Keable, 16 Oct 2001.

QLD 1570 Reef slope S of "Washing Machine", NE side of Lizard Island, Queensland, mixed hydroids (Aglaophenia sp., Gymnangium gracilicaule, Macrorhynchia philippina and large unidentified species), collected by hand on SCUBA, 3 m, J.M. Guerra-García \& S.J. Keable, 16 Oct 2001.

QLD 1571 Reef slope S of "Washing Machine", NE side of Lizard Island, Queensland, large brown sponge cf. Jaspis sp., collected by hand on SCUBA, 15-20 m, J.M. Guerra-García \& S.J. Keable, 16 Oct 2001.

QLD 1572 Reef slope S of "Washing Machine", NE side of Lizard Island, Queensland, fine sand with small amount of fine shell, collected by hand on SCUBA, 20-25 m, J.M. Guerra-García \& S.J. Keable, 16 Oct 2001.

QLD 1573 Reef slope S of "Washing Machine", NE side of Lizard Island, Queensland, mixed silty filamentous red algae (not yet collected at previous stations) a little Caulerpa taxifolia, collected by hand on SCUBA, 6 m, J.M. Guerra-García \& S.J. Keable, 16 Oct 2001.

QLD 1574Off front of patch reefs at N end of Casuarina Beach, Lizard Island, Queensland, medium grained sand, collected by hand on snorkel, $4 \mathrm{~m}$, J.M. Guerra-García \& S.J. Keable, 16 Oct 2001.

QLD 1575 No Name Reef, Dynamite Passage outer Great Barrier Reef east of Lizard Island, Queensland, medium-fine grained sand with some silt, collected by hand on SCUBA, $10 \mathrm{~m}$, J.M. Guerra-García \& S.J. Keable, 17 Oct 2001.
QLD 1576 No Name Reef, Dynamite Passage outer Great Barrier Reef east of Lizard Island, Queensland, hydroid Macrorhynchia philippina, collected by hand on SCUBA, 10 m, J.M. GuerraGarcía \& S.J. Keable, 17 Oct 2001.

QLD 1578 Pidgin Point, Lizard Island, Queensland, compact globular tan coloured sponge cf. Xentospongia sp. with some algal turf covering (fiborous when cut) from under coral ledge, collected by hand on SCUBA, 20 m, J.M. Guerra-García \& S.J. Keable, 18 Oct 2001.

QLD 1579 Pidgin Point, Lizard Island, Queensland, hydroid Macrorhynchia philippina near sediment, collected by hand on SCUBA, 20-25 m, J.M. Guerra-García \& S.J. Keable, 18 Oct 2001

QLD 1580 Pidgin Point, Lizard Island, Queensland, hydroid Halopteris buskii., collected by hand on SCUBA, 5-10 m, J.M. GuerraGarcía \& S.J. Keable, 18 Oct 2001.

QLD 1581 Pidgin Point, Lizard Island, Queensland, sponge cf. Clathria reinwardti, collected by hand on SCUBA, $20 \mathrm{~m}$, J.M. GuerraGarcía \& S.J. Keable, 18 Oct 2001.

QLD 1582 Pidgin Point, Lizard Island, Queensland, fine-medium sand with small amount of shell and coral gravel, collected by hand on SCUBA, 26 m, J.M. Guerra-García \& S.J. Keable, 18 Oct 2001.

QLD 1585 Reef just SW of Osprey Island, Lizard Island, Queensland, large amount of hydroid Macrorhynchia philippina, collected by hand on SCUBA, 5-10 m, J.M. Guerra-García \& S.J. Keable, 18 Oct 2001.

QLD 1588 Reef just SW of Osprey Island, Lizard Island, Queensland, fine-medium sand with some shell, collected by hand on SCUBA, 10-12 m, J.M. Guerra-García \& S.J. Keable, 18 Oct 2001. 